\title{
AVALIAÇÃO DA POLPA DE CITROS SECA E PELETIZADA COMO ADITIVO NA ENSILAGEM DO CAPIM ELEFANTE (Pennisetum purpureum, SCHUM)
}

\author{
JOSÉ ROBERTO PERES
}

Engenheiro Agrônomo

Orientador: Prof. Dr. Celso Boin

Dissertação apresentada à Escola Superior de Agricultura "Luiz de Queiroz", da Universidade de São Paulo, para obtenção do título de Mestre em Agronomia, área de concentração: Ciência Animal e Pastagens.

PIRACICABA

Estado de São Paulo - Brasil

Janeiro de 1997 
Dados Internacionais de Catalogação na Publicação (CIP)

DIVISÃO DE BIBLIOTECA E DOCUMENTAÇÃO - Campus "Luiz de Queiroz"/USP

Peres, José Roberto

Avaliação da polpa de citros seca e peletizada como aditivo na ensilagem do capim elefante ( Pennisetum purpureum, SCHUM) / José Roberto Peres. - . - . . . - . Piracicaba, 1977.

$82 \mathrm{p}$.

Dissertação (mestrado) - - Escola Superior de Agricultura "Luiz de Queiroz", 1997. Bibliografia.

1. Capim elefante 2. Digestibilidade 3. Polpa de fruta cítrica I. Título

CDD 636.08552

633.2 


\section{AVALIAÇÃO DA POLPA DE CITROS SECA E PELETIZADA COMO ADITIVO NA ENSILAGEM DO CAPIM ELEFANTE \\ (Pennisetum purpureum, SCHUM)}

José Roberto Peres

Aprovado em: 18 de abril de 1997.

Comissão Julgadora:

Prof. Dr. Wagner Lavezzo

UNESP/Botucatu

Prof. Dr. Flávio Augusto Portela Santos

ESALQ/USP

Prof. Dr. Celso Boin

ESALQ/USP

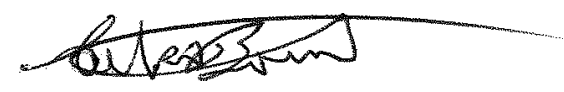

Prof. Dr. Celso Boin

Orientador 


\section{DEDICATÓRIA}

"Aos meus pais que sempre me orientaram, apoiaram e incentivaram para que eu pudesse chegar até aqui." 


\section{AGRADECIMENTOS}

Ao Prof. Paulo Fernando Machado pela orientação incial.

Ao Prof. Celso Boin por ter me acolhido e orientado, sem restrições, mesmo quando já havia decorrido metade do curso.

Ao Prof. Wilson Mattos pela cessão do Laboratório de Bromatologia.

À professora Ivanete Suzin pelo empréstimo dos carneiros.

À Fundação de Amparo à Pesquisa do Estado de São Paulo (FAPESP), pelo financiamento do projeto.

Ao Conselho Nacional de Desenvolvimento Científico e Tecnológico (CNPq), pela concessão da bolsa de estudos.

À CTM Citros, que forneceu a polpa de citros para o experimento.

Ao Eng. Agr. Wiliam Tabchoury que, representando a fazenda Tainá, forneceu o capim para a realização do experimento

Ao Departamento de Zootecnia por fornecer as gaiolas metabólicas as instalações e o laboratório.

Ao Prof. Sila Carneiro pela orientação inicial para realização da análise estatística.

Ao laboratorista Cesar Alves, pela amizade e apoio na realização das análises.

Ao Jozivaldo Prudêncio, pela amizade, auxílio e ensinamentos durante todo o experimento.

Ao Clube de Práticas Zootécnicas (CPZ), pelo grande auxilio na confecção das silagens.

Aos colegas da turma de 1995 de mestrado em Ciência Animal e Pastagens pelo auxílio na confecção das silagens.

Ao estagiário André pelo auxílio na condução do experimento. 


\section{SUMÁRIO}

SUMÁRIO ..................................................................................................................................iii

LISTA DE TABELAS DO TEXTO ....................................................................................................... iv

LISTA DE TABELAS DO APÊNDICE .................................................................................................... v

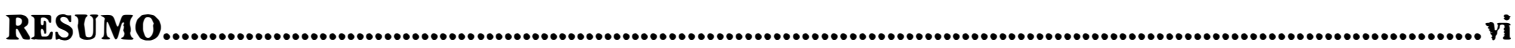

SUMMARY ................................................................................................................................................. ix

1. INTRODUÇÃO ............................................................................................................................................1

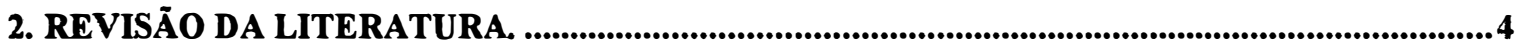

2.1 Parâmetros básicos para avaliação de silagens ............................................................................ 4

2.2 Técnicas para aumentar 0 teor de matéria seca do capim elefante .......................................... 7

2.3 Aditivos na ensilagem do capim elefante ....................................................................................... 8

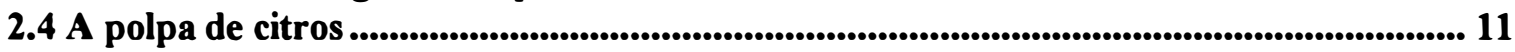

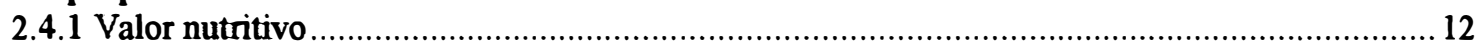

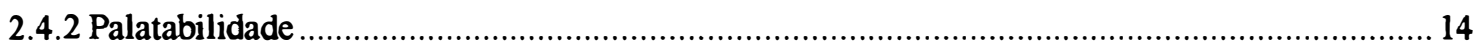

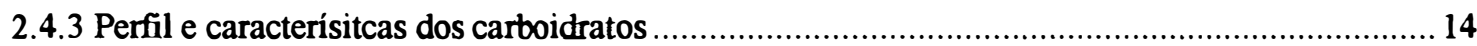

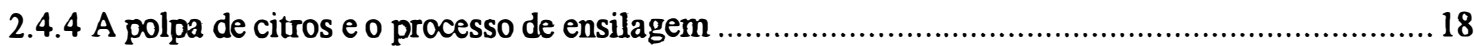

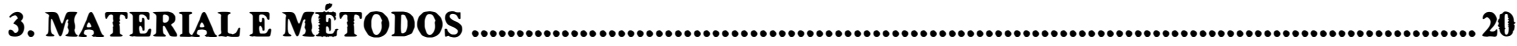

3.1 Ensaio de conservação em silos experimentais............................................................ 22

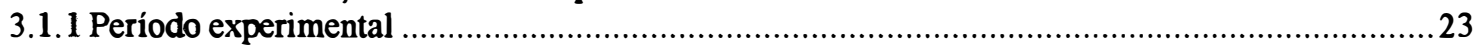

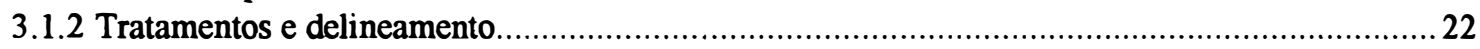

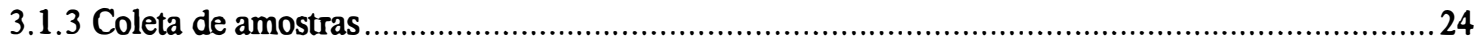

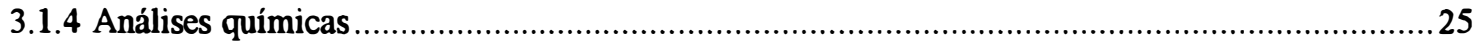

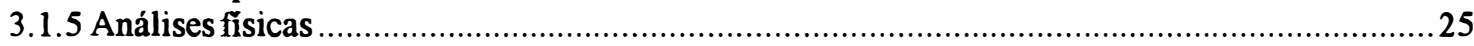

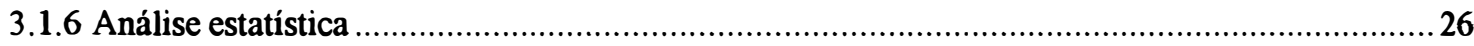

3.2 Ensaio de digestibilidade "in vivo" em carneiros................................................................. 26

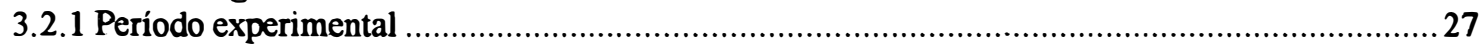

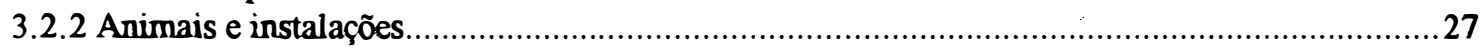

3.2.3 Tratamentos e delineamento

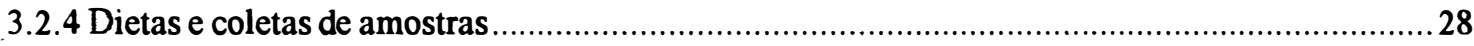

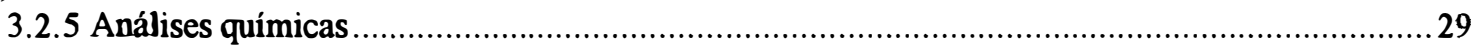

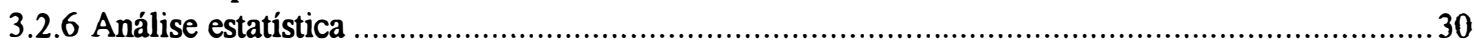

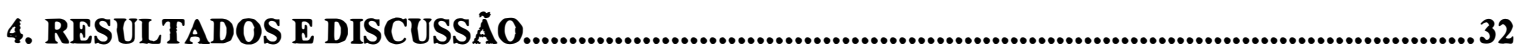

4.1 - Ensaio de consevação em silos de laboratório ............................................................. 32

4.2 - Ensaio de digestibilidade.......................................................................................................................... 38

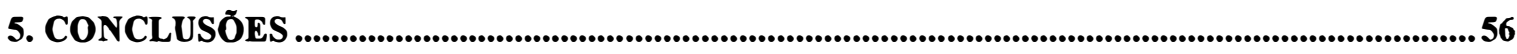

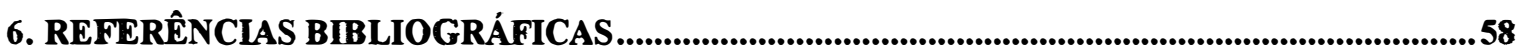

7. APÊNDICE - OBSERVAÇÕES REALIZADAS PARA OS DIVERSOS PARÂMETROS...........69 


\section{LISTA DE TABELAS DO TEXTO}

Tabela 1: Teor e recuperação da matéria seca (\%) ...................................................................... 32

Tabela 2: Volume de efluente dos silos experimentais ........................................................................ 34

Tabela 3: Parâmetros de conservação das silagens ................................................................ 35

Tabela 4: Carboidratos solúveis e poder tampão do material antes da ensilagem................. 36

Tabela 5: Teor e consumo de matéria seca, digestibilidade da matéria seca, digestibilidade da

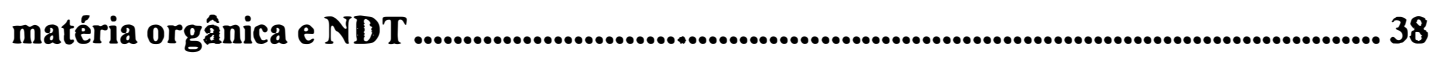

Tabela 6: Teor de proteína bruta e suas frações e digestibilidade da proteína bruta........... 43

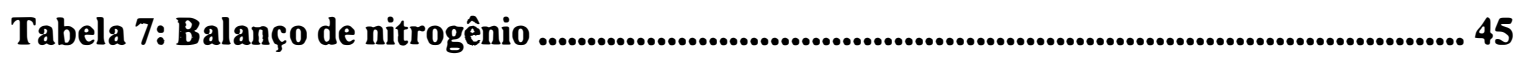

Tabela 8: Composição bromatológica e digestibilidade da fração fibrosa............................... 48

Tabela 9: Análise da fração fibrosa da polpa de citros por duas metodologias....................... 51

Tabela 10: Teor e digestibilidade das frações do conteúdo celular. ......................................... 55 


\section{LISTA DE TABELAS DO APÊNDICE}

Tabela A1: Recuperação da matéria seca (\%) ................................................................................... 69

Tabela A2: pH das silagens.................................................................................................................... 69

Tabela A3: Nitrogênio amoniacal (\% do N-T otal) ...................................................................... 69

Tabela A4: Teor de matéria seca das silagens. (trat. x periodo) .................................................. 70

Tabela A5: Consumo de matéria seca (g/kg de peso metabólico). (trat. $\times$ carneiro) ............... 70

Tabela A6: Digestibilidade da matéria seca (\%). (trat. x carneiro).............................................. 70

Tabela A7: Digestibilidade da matéria orgânica (\%). (trat. x carneiro) ..................................... 71

Tabela A8: Teor de proteina bruta (\%) das silagens (trat. $x$ carneiro) ...................................... 71

Tabela A9: Digestibilidade da proteína bruta das silagens (trat. $\mathrm{x}$ carneiro)........................... 71

Tabela A10: Teor de FDA (\%) das silagens (trat. $x$ carneiro) - análise tradicional................ 72

Tabela A11: Digestibilidade da FDA das silagens (trat. x carneiro) - tradicional ................... 72

Tabela A12: Teor de FDN (\%) das silagens (trat. $x$ carneiro) - tradicional............................. 72

Tabela A13: Digestibilidade da NDF das silagens (trat. $x$ carneiro) - tradicional................... 73

Tabela A14: Teor de Lignina (\%) das silagens (trat. $x$ carneiro)................................................ 73

Tabela A15: Digestibilidade da Lignina das silagens (trat. $x$ carneiro) ...................................... 73

Tabela A16: Teor de Celulose (\%) das silagens (trat. $x$ carneiro) - tradicional....................... 74

Tabela A17: Digestibilidade da Celulose das silagens (trat. $x$ carneiro) - tradicional ............ 74

Tabela A18: Teor de Hemicelulose (\%) das silagens (trat. x carneiro) - tradicional ............. 74

Tabela A19: Digestib. da Hemicelulose das silagens (trat. x carneiro) - tradicional ............... 75

Tabela A20: Teor de Carboidratos Não Estruturais das silagens (trat. x carneiro).............. 75

Tabela A21: Digestib. dos Carboid. Não Estruturais das silagens (trat. x carneiro) .............. 75

Tabela A22: Teor de FDA (\%) das silagens (trat. x carneiro) - análise sequencial................. 76

Tabela A23: Digestibilidade da FDA das silagens (trat. x carneiro) - sequencial..................... 76

Tabela A24: Teor de FDN (\%) das silagens (trat. $x$ carneiro) - sequencial .............................. 76

Tabela A25: Digestibilidade da NDF das silagens (trat. x carneiro) - sequencial..................... 77

Tabela A26: Teor de Celulose (\%) das silagens (trat. x carneiro) - sequencial....................... 77

Tabela A27: Digestibilidade da Celulose das silagens (trat. x carneiro) - sequencial .............. 77

Tabela A28: Teor de Hemicelulose (\%) das silagens (trat. x carneiro) - sequencial............... 78

Tabela A29: Digestib. da Hemicelulose das silagens (trat. x carneiro) - sequencial ................ 78

Tabela A30: Teor de fibra bruta (\%) das silagens (trat. $x$ carneiro) .......................................... 78

Tabela A31: Digestibilidade da fibra bruta das silagens (trat. x carneiro)................................. 79

Tabela A32: Teor de extrato etéreo (\%) das silagens (trat. $x$ carneiro)................................... 79

Tabela A33: Digestibilidade do extrato etéreo das silagens (trat. $x$ carneiro) .......................... 79

Tabela A34: Teor de extrativo não nitrogenado (\%) das silagens (trat. x carneiro)............... 80

Tabela A35: Digestibilidade do extrativo não nitrog. das silagens (trat. $x$ carneiro) .............. 80

Tabela A36: Nutrientes digestíveis totais das silagens (trat.x carneiro)..................................... 80

Tabela A37: Teor de nitrogênio insolúvel na FDA - \% do $\mathbf{N}$ total (trat. x carneiro) .............. 81

Tabela A38: Teor de nitrogênio insolúvel na FDN - \% do $\mathbf{N}$ total (trat. x carneiro) .............. 81

Tabela A39: Teor de nitrogênio solúvel - \% do $\mathrm{N}$ total (trat. $\mathrm{x}$ carneiro).................................. 81

Tabela A40: Teor de nitrogênio não protéico - \% do $\mathrm{N}$ total (trat. $x$ carneiro)....................... 82

Tabela A41: Teor de nitrogênio não protéico - \% do N solúvel (trat. x carneiro).................. 82 


\title{
AVALIAÇÃO DA POLPA DE CITROS SECA E PELETIZADA COMO ADITIVO NA A ENSILAGEM DO CAPIM ELEFANTE \\ (Pennisetum purpureum, SCHUM.)
}

\author{
Autor: JOSÉ ROBERTO PERES \\ Orientador: PROF. DR. CELSO BOIN
}

\section{RESUMO}

Este trabalho teve por objetivo avaliar o efeito da adição da polpa de citros seca e peletizada na ensilagem do capim elefante. O trabalho foi dividido em duas fases: na primeira (Experimento I) foi avaliado o efeito da aditivação na conservação do material ensilado e recuperação de matéria seca através de um delineamento inteiramento casualizado com 5 tratamentos e 5 repetições. Foram utilizados 25 silos de laboratório, onde os seguintes tratamentos foram constituídos: $0,5,10$ e $15 \%$ de polpa de laranja e um tratamento com $10 \%$ de fubá de milho como termo de comparação. O nível de polpa utilizado afetou o teor de matéria seca das silagens tendo sido observado aumento significativamente positivo $(\mathrm{P}<0,05)$, com os dois tratamentos com maior nível de polpa se igualando ao tratamento com $10 \%$ de fubá de milho. A maior recuperação da matéria seca ocorreu no tratamento com $10 \%$ de polpa de citros $(\mathrm{P}<0,05 \%)$, e a menor ocorreu no tratamento com $10 \%$ de fubá de milho. Os demais tratamentos apresentaram valores intermediários de recuperação da matéria seca, ou seja, respectivamente $81,3^{\text {bc }} ; 86,4^{\text {ab }}$, $91,1^{\mathrm{a}} ; 80,0^{\mathrm{bc}}$ e $77,4^{\mathrm{c}} \%$ para os tratamentos com $0,5,10,15 \%$ de polpa de citros e $10 \%$ de fubá de milho. Também foi avaliado o volume de efluente, sendo que este só ocorreu nos três primeiros tratamentos $(0,5$ e $10 \%$ de polpa), com valores médios respectivamente de 40,$4 ; 2,5$ e $2,0 \mathrm{ml}$ por $\mathrm{kg}$ de material ensilado, demonstrando que a polpa foi bastante efetiva como absorvente. Pode-se afirmar que todos os tratamentos 
apresentaram boa conservação, constatada pelos valores adequados de $\mathrm{pH}(3,8 ; 3,8 ; 3,8$; $3,9 ; 3,8)$, baixos niveis de nitrogênio amoniacal $\left(12,7^{\mathrm{a}} ; 11,8^{\mathrm{ab}} ; 11,5^{\mathrm{ab}} ; 10,9^{\mathrm{b}} ; 12,5^{\mathrm{a}} \%\right.$ do nitrogênio total) e de ácido butírico $(0,053 ; 0,22 ; 0,047 ; 0,058 ; 0,147 \%$ na matéria seca).

No experimento II foi avaliada a digestibilidade aparente "in vivo" das silagens e o balanço nitrogenado, através da utilização de 6 carneiros da raça corriedale. Neste experimento, além dos tratamentos já mencionados foi adicionado um sexto tratamento que consistiu de uma silagem de milho como termo de comparação. Devido à quantidade insuficiente de silagem em alguns tratamentos, foram realizados somente 5 períodos, sendo que a análise estatística foi realizada como um delineamento em quadrado latino incompleto. Os períodos consistiram de 14 dias de adaptação e 7 dias de coleta, onde era feita uma restrição alimentar a $90 \%$ do consumo voluntário.

A aditivação aumentou o teor de matéria seca das silagens $\left(18,9^{\mathrm{d}} ; 21,4^{\mathrm{c}} ; 25,8^{\mathrm{b}}\right.$; $27,7^{\mathrm{a}} ; 26,1^{\mathrm{b}} ; 25,1^{\mathrm{b}} \%$ de MS, respecetivamente para os tratamentos com $0 ; 5 ; 10 ; 15 \%$ de polpa; $10 \%$ de fubá e para a silagem de milho), bem como seu consumo voluntário $\left(35,8^{\mathrm{d}} ; 39,9^{\mathrm{cd}} ; 46,5^{\mathrm{b}} ; 49,7^{\mathrm{ab}} ; 50,9^{\mathrm{a}} ; 41,9^{\mathrm{c}} \mathrm{g} / \mathrm{kg} \mathrm{PV}^{.75}\right)$.

O teor de proteína bruta $\left(6,2^{\mathrm{c}} ; 6,4^{\mathrm{bc}} ; 6,5^{\mathrm{bc}} ; 6,8^{\mathrm{b}} ; 7,6^{\mathrm{a}} ; 8,3^{\mathrm{a}} \%\right.$ na MS), foi inferior nos tratamentos testemuha e com adição da polpa de citros, enquanto que sua digestibilidade foi inferior até o nível de $10 \%$ de polpa de citros $\left(44,7^{\mathrm{b}} ; 44,4^{\mathrm{b}} ; 45,2^{\mathrm{b}}\right.$; $\left.51,9^{\mathbf{a}} ; 55,5^{\mathbf{a}} ; 52,3^{\mathbf{a}} \%\right)$. Os níveis de nitrogênio insolúvel em detergente ácido $\left(12,9^{\mathbf{b c}}\right.$, $14,4^{\text {ab. }}, 16,9^{\mathrm{a}} ; 14,8^{\mathrm{ab}} ; 7,9^{\mathrm{d}} ; 11,2^{\mathrm{c}} \%$ do nitrogênio total) e em detergente neutro $\left(15,9^{\mathrm{c}}\right.$; $19,2^{\mathrm{b}} ; 22,3^{\mathrm{a}} ; 22,6^{\mathrm{a}} ; 12,1^{\mathrm{d}} ; 14,5^{\text {cd }} \%$ do nitrogênio total) encontrados nas silagens aditivadas com polpa foram significativamente mais elevados $(P<0,05)$ que os determinados para a testemunha e os demais tratamentos. Maior quantidade de nitrogênio solúvel $\left(54,7^{\mathrm{c}} ; 56,1^{\mathrm{bc}} ; 56,6^{\mathrm{bc}} ; 58,3^{\mathrm{b}} ; 62,6^{\mathrm{a}}\right.$ e $65,6^{\mathrm{a}} \%$ do nitrogênio total) foi determinada nas silagens de milho e com fubá, porém maior proporção de nitrogênio não protéico $\left(84,4^{\mathrm{a}} ; 80,4^{\mathrm{ab}} ; 78,5^{\mathrm{ab}} ; 73,1^{\mathrm{b}} ; 61,6^{\mathrm{c}}\right.$ e $53,7^{\mathrm{c}} \%$ do nitrogênio solúvel) foi encontrada nas silagens de napier, aditivada com polpa ou não. $O$ balanço nitrogenado negativo $\left(-6,2^{b_{0}} \%\right.$ de nitrogênio retido em relação ao ingerido) e muito próximo a zero $\left(4,9^{b_{0}} \% \mathrm{~N}\right.$-retido/ $\mathrm{N}$ ingerido) determinados respectivamente nos tratamentos testemunha e com $5 \%$ de polpa 
de citros demonstram que a quantidade ou ainda a disponibilidade da proteína foram insuficientes para ótimo aproveitamento das silagens pelos animais. Os níveis mais elevados de polpa de citros (10 el5\%), o fubá de milho (10\%) e a silagem de milho permitiram balanço nitrogenado positivo, a saber: $17,5^{\mathrm{a}} ; 24,2^{\mathrm{a}} ; 27,1^{\mathrm{a}}$ e $21,3^{\mathrm{a}} \%$ de nitrogênio retido em relação ao ingerido, respectivamente.

Houve aumento da digestibilidade da matéria seca $\left(53,8^{\mathrm{e}} ; 56,1^{\mathrm{de}} ; 60,7^{\mathrm{bc}}, 62,4^{\mathrm{ab}}\right.$, $64,9^{\mathrm{a}}$ e $58,9^{\text {cd }} \%$ respectivamente para os tratamentos com $0 ; 5 ; 10 ; 15 \%$ de polpa; $10 \%$ de fubá e para a silagem de milho) e do teor de nutrientes digestíveis totais $\left(52,9^{\mathrm{c}} ; 55,2^{\mathrm{c}}\right.$; $59,5^{\mathrm{b}} ; 60,9^{\mathrm{b}} ; 65,7^{\mathrm{a}}$ e $59,2^{\mathrm{b}} \%$ ), com a aditivação.

Os resultados mostraram que a polpa de citros é um bom aditivo para a ensilagem do capim elefante proporcionando boa conservação do material. 


\title{
EVALUATION OF DRIED PELLETED CITRUS PULP AS AN ADDITIVE IN THE ENSILAGE OF ELEPHANT GRASS \\ (Pennisetum purpureum, SCHUM.)
}

\author{
Author: JOSÉ ROBERTO PERES \\ Adviser: PROF. DR. CELSO BOIN
}

\section{SUMMARY}

The objective of this two phases study was to evaluate the addition of dried pelleted citrus pulp in the ensiling process of elephant grass. In the first phase (experiment I), the additive effects were evaluated through conservation parameters and dry matter recovery from 25 small laboratory silos. In a 5 treatment and 5 repetition, totally randomized design, the following treatments were analyzed: 0, 5, 10 e 15\% dried citrus pulp and one treatment using $10 \%$ milled corn as an alternative. The level of citrus pulp influenced the silage dry matter $(\mathrm{P}<0,05)$. The $10 \%$ and $15 \%$ citrus pulp treatment were similar to the $10 \%$ milled com and superior to the others. The $10 \%$ citrus pulp treatment had the better dry matter recovery. The $10 \%$ milled corn resulted in the lowest dry matter recovery. All other treatments were intermediary (respectively $81,3^{\text {bc }} ; 86,4^{\text {bb }} ; 91,1^{a} ; 80,0^{b c}$ e $77,4^{\mathrm{c}} \%$ for treatments using $0,5,10,15 \%$ of citrus pulp and $10 \%$ milled com). The effluent (present only in the 0;5 and 10\% treatments) was collected and the volumes $(40,4 ; 2,5$ and $2,0 \mathrm{ml}$ per $\mathrm{kg}$ of ensiled material), demonstrated the effectiveness of the citrus pulp as an absorbent. It is possible to say that all treatments had a good conservation, confirmed by the adequate $\mathrm{pH}$ values $(3,8 ; 3,8 ; 3,8 ; 3,9 ; 3,8)$, low levels of both ammonia nitrogen $\left(12,7^{\mathrm{a}}, 11,8^{\mathrm{ab}} ; 11,5^{\mathrm{ab}} ; 10,9^{\mathrm{b}} ; 12,5^{\mathrm{a}} \%\right.$ of total nitrogen) and butyric acid $(0,053 ; 0,022 ; 0,047 ; 0,058 ; 0,147 \%$ of dry matter) observed. 
In experiment II the "in vivo" apparent digestibility and nitrogen balance of the silages was determined through 6 corriedale lambs. In this trial an extra treatment composed of corn silage was introduced as comparison. Because of insufficient amounts of some silage treatments, the design consisted of an unbalanced latin square (6 treatments and 5 periods). Each experimental period consisted of 14 adaptation days and 7 collection days, when a consumption restriction to $90 \%$ of voluntary intake was imposed.

The level of citrus pulp increased both the silages dry matter content $\left(18,9^{\mathrm{d}} ; 21,4^{\mathrm{c}}\right.$; $25,8^{\mathrm{b}} ; 27,7^{\mathrm{a}} ; 26,1^{\mathrm{b}} ; 25,1^{\mathrm{b}} \%$ of DM, respectively for $0 ; 5 ; 10 ; 15 \%$ pulp; $10 \%$ milled corn and corn silage), and voluntary intake $\left(35,8^{\mathrm{d}} ; 39,9^{\mathrm{cd}}, 46,5^{\mathrm{b}} ; 49,7^{\mathrm{ab}} ; 50,9^{\mathrm{a}} ; 41,9^{\mathrm{c}} \mathrm{g} / \mathrm{kg}\right.$ $\mathrm{LW}^{.75}$.

The crude protein content $\left(6,2^{\mathrm{c}} ; 6,4^{\mathrm{bc}} ; 6,5^{\mathrm{bc}} ; 6,8^{\mathrm{b}} ; 7,6^{\mathrm{a}} ; 8,3^{\mathrm{a}} \%\right.$ of DM) was lower in the control and citrus pulp treatments, while its digestibility was lower until the level of $10 \%$ of citrus pulp addition $\left(44,7^{\mathrm{b}} ; 44,4^{\mathrm{b}} ; 45,2^{\mathrm{b}} ; 51,9^{\mathrm{a}} ; 55,5^{\mathrm{a}} ; 52,3^{\mathrm{a}} \%\right.$ of CP). The levels of acid detergent insoluble nitrogen $\left(12,9^{\mathrm{bc}} ; 14,4^{\mathrm{ab}} ; 16,9^{\mathrm{a}} ; 14,8^{\mathrm{ab}} ; 7,9^{\mathrm{d}} ; 11,2^{\mathrm{cc}} \%\right.$ of total $\mathrm{N}$ ) and neutral detergent insoluble nitrogen $\left(15,9^{\mathrm{c}} ; 19,2^{\mathrm{b}} ; 22,3^{\mathrm{a}} ; 22,6^{\mathrm{a}} ; 12,1^{\mathrm{d}} ; 14,5^{\mathrm{cd}} \%\right.$ of total $\mathrm{N})$ found in the citrus pulp silages were significantly higher $(\mathrm{P}<0,05)$ than the ones determined for the control and other treatments. Greater amount of soluble nitrogen $\left(54,7^{\mathrm{c}} ; 56,1^{\mathrm{bc}} ; 56,6^{\mathrm{bc}} ; 58,3^{\mathrm{b}} ; 62,6^{\mathrm{a}}\right.$ e $65,6^{\mathrm{a}} \%$ of total nitrogen) was determined in the corn silage and $10 \%$ milled corn and grass silage, although a greater proportion of non protein nitrogen $\left(84,4^{\mathrm{a}} ; 80,4^{\mathrm{ab}} ; 78,5^{\mathrm{ab}} ; 73,1^{\mathrm{b}} ; 61,6^{\mathrm{c}}\right.$ e $53,7^{\mathrm{c}} \%$ of soluble nitrogen) was found in the grasses silages, in comparison to corn silage. The negative nitrogen balance $\left(-6,2^{b_{0}} \%\right.$ de nitrogen retained in relation to ingested) and very close to zero $\left(4,9^{b_{0}} \% \mathrm{~N}\right.$-retained $/ \mathrm{N}$ ingested) determined respectively for the control and $5 \%$ citrus pulp show a deficiency in protein in these treatments for optimal response. The higher levels of citrus pulp (10 and $15 \%)$, the milled corn (10\%) and the corn silage allowed a positive nitrogen balance, as follows: $17,5^{\mathrm{a}} ; 24,2^{\mathrm{a}} ; 27,1^{\mathrm{a}}$ and $21,3^{\mathrm{a}} \% \mathrm{~N}$-retained $/ \mathrm{N}$-ingested, respectively.

The dry matter digestibility $\left(53,8^{\mathrm{e}} ; 56,1^{\mathrm{de}} ; 60,7^{\mathrm{bc}} ; 62,4^{\mathrm{ab}} ; 64,9^{\mathrm{a}}\right.$ and $58,9^{\mathrm{bc}} \%$ respectively for $0 ; 5 ; 10 ; 15 \%$ citrus pulp; $10 \%$ milled corn and corn silage) and the total 
digestible nutrients $\left(52,9^{\mathrm{c}} ; 55,2^{\mathrm{c}} ; 59,5^{\mathrm{b}} ; 60,9^{\mathrm{b}} ; 65,7^{\mathrm{a}}\right.$ e $\left.59,2^{\mathrm{b}} \%\right)$, increased with additivation.

The citrus pulp showed to be an effective additive for the ensilage of elephant grass, allowing good conservation. 


\section{INTRODUÇÃO}

O capim elefante (Pennisetum purpureum, Schum.), segundo Otero ${ }^{1}$, citado por LAVEZZO (1993), foi introduzido no Brasil por volta de 1920. Em função de suas características intrínsecas de rusticidade, alta produção, facilidade de multiplicação, disponibilidade de inúmeras variedades e cultivares, boa apetibilidade para os animais, elevada resistência a pragas e doenças, relativa resistência à seca, adaptação aos diversos tipos de solos e bom valor nutritivo quando novo, esta gramínea difundiu-se pelo país e vem sendo utilizada no meio pecuário sob diversas formas.

Historicamente, o capim elefante foi largamente empregado para a formação de capineiras. de FARIA (1993) reputa esta popularidade à sua elevada produção, que pode atingir, quando a espécie é bem manejada, até 80 toneladas de matéria seca por hectare/ano. As capineiras são utilizadas como suplementação de volumosos nas épocas críticas do ano. No entanto, deficiências de manejo das capineiras, com cortes em estágios bastante avançados de crescimento, para obtenção de maiores produções, fazem com que seu valor nutritivo seja bastante reduzido, proporcionando resultados zootécnicos inconsistentes (LAVEZZO, 1993).

Dentre outras modalidades de utilização do capim elefante, o feno parece não ser uma opção viável, uma vez que a planta possui hastes grossas, que dificultam a secagem rápida e uniforme, quando comparadas às folhas. Quando somamos isto às dificuldades próprias desta técnica, como a falta de maquinário apropriado, dependência do clima, etc., fica fácil entender o motivo da impopularidade da mesma.

Esta gramínea possui também grande potencial quando corretamente maneajado sob a forma de pastagem. de FARIA (1993) afirma que diversos trabalhos científicos, realizados no Brasil e no exterior, demonstraram que o capim elefante, quando bem manejado, apresenta alto potencial de produção, o que pode trazer grande contribuição

\footnotetext{
${ }^{1}$ OTERO, J.R. Informaçð̃es sobre algumas plantas forrageiras. Rio de Janeiro, Ministério da Agricultura, Serviço de Informação Agrícola, 1952, 313p.
} 
ao setor pecuário nacional, liberando áreas das fazendas para outras atividades e intensificando o processo produtivo.

O enfoque mais freqüentemente utilizado para este tipo de exploração é o do manejo intensivo, que tem por princípio, explorar todo o potencial de produção da forragem na época em que as condições para seu desenvolvimento são mais favoráveis (verão). Este tipo de manejo exige que as pastagens de alta produção estejam associadas a sistemas de alimentação do rebanho durante o período de escassez de produção (inverno). Esse fato se deve à necessidade de manter o mesmo número de animais em pastagens tanto no "verão" quanto no "inverno", e isto só é possível através da utilização de tecnologias de conservação de forragens (CORSI, 1986). LAVEZZO (1993), afirma que "é sob este prisma que a ensilagem do capim elefante passa a ter papel preponderante, pois não existe, à luz da experimentação, forma mais adequada para a conservação do excesso de produção dessa forragem no "verão" (que se constitui em 70 a $80 \%$ da produção total total).

Já foi demonstrado exaustivamente (ANDRADE e GOMIDE, 1971; PRÓSPERO, 1972 e SLVEIRA et al., 1973ª) que as gramíneas forrageiras tropicais, com o avançar do crescimento vegetativo, aumentam sua produção por área, tendo em contrapartida, seu valor nutritivo diminuido. Nestas condições, consequentemente, o produto obtido no processo de ensilagem tambem é de baixo valor nutritivo. Por outro lado, quando estas são ensiladas em estádio de desenvolvimento mais novo, segundo WOOLFORD (1984), três de suas características podem interferir sobre o processo da ensilagem: alto teor de umidade, alta capacidade tampão e baixos teores de carboidratos solúveis. Tais fatores influem negativamente sobre o processo fermentativo, impedindo o rápido decréscimo do $\mathrm{pH}$ a níveis adequados $(3,8$ a 4,2) e permitindo, assim, fermentações secundárias indesejáveis, prejudicando, como conseqüência, a qualidade do produto preservado. Este tem sido o principal entrave encontrado pelos técnicos para a confecção de silagens de capim elefante de boa qualidade. Nesse sentido, diversas técnicas têm sido testadas na tentativa de sanar estes problemas. 
A polpa de citros é um subproduto da extração do suco da laranja que possui alta capacidade de absorção de água, alto teor de carboidratos solúveis, alto valor nutritivo, boa palatabilidade, entre outras características que a apontam como suplemento ideal para a viabilização da ensilagem do capim elefante.

Este trabalho teve por finalidade estudar a viabilidade da utilização da polpa de citros seca e peletizada como aditivo para a ensilagem do capim elefante e sua digestibilidade aparente em carneiros. 


\section{REVISÃO DA LITERATURA.}

\subsection{Parâmetros básicos para avaliação de silagens}

Os princípios básicos da ensilagem incluem, em primeiro lugar, a obtenção de condições anaeróbias dentro do silo. Conjuntamente, também deve ser desencorajada a atividade de bactérias butíricas, o que é feito normalmente através de fermentações láticas. As bactérias láticas produzem ácido lático, que aumenta a concentração hidrogeniônica do meio a um nível que inibe o desenvolvimento das bactérias butíricas. Porém, é dificil o estabelecimento do exato valor crítico de $\mathrm{pH}$ no qual esta inibição ocorre, uma vez que a mesma ocorre não somente em função do $\mathrm{pH}$, mas também do teor de umidade. Quanto mais úmido o material, mais baixo é o $\mathrm{pH}$ crítico necessário para que a inibição ocorra (McDONALD, 1981).

WIERINGA (1960) concluiu que os clostrídeos são mais inibidos pela carência de umidade do que pela acidez do meio. Os microorganismos do gênero Clostridium podem tolerar altas concentrações de ácidos e íons hidrogênio quando em meio úmido, e sua resistência é diretamente proporcional ao teor de umidade. Isto implica que os clostrídeos são sensíveis ao aumento da pressão osmótica (diminuição da atividade da água).

Para um rápido abaixamento do $\mathrm{pH}$ também é imprescindível que exista no meio suficiente quantidade de carboidratos solúveis a serem fermentados pelas bactérias láticas e que o poder tampão não seja capaz de impedir o abaixamento do $\mathrm{pH}$ aos níveis desejados. A relação entre o teor de carboidratos solúveis e o poder tampão da forragem foi utilizada por WEISSBACH et al. (1974) para antecipar a qualidade final de produtos ensilados. Através de experimentos fatoriais com diversas forragens em silos experimentais eles desenvolveram uma equação para previsão do resultado final da fermentação, utilizando como parâmetros o teor de matéria seca e a relação Z/PK, onde $\mathrm{Z}$ representa a quantidade de carboidratos solúveis do material ensilado (porcentagem na matéria seca) e PK é o seu poder tampão (quantidade de ácido lático necessário para acidificação da forragem até um $\mathrm{pH}=4,0$; medida em gramas de ácido lático por 100 
gramas de matéria seca). Utilizando um modelo matemático, o teor crítico de matéria seca para silagens livres de ácido butírico foi determinado em cada experimento. Posteriormente, através de análise estatística dos resultados foi determinada uma equação para determinação do teor de matéria seca necessário na forragem, para que a silagem apresentasse boa qualidade, em função da sua relação Z/PK. A equação permite, portanto, a previsão da necessidade de se aumentar o teor de matéria seca do material a ser ensilado, seja pela pré-secagem, seja pela adição de material absorvente. A relação determinada foi a seguinte: $\mathrm{Y}=45-8 \mathrm{X}$, onde $\mathrm{X}=$ quociente $\mathrm{Z} / \mathrm{PK} ; \mathrm{Y}=$ requerimento de matéria seca para obtenção de silagem de alta qualidade fermentativa.

GUTIERREZ e de FARIA (1979), estudando os níveis de carboidratos solúveis de quatro variedades de capim elefante colhidas aos 37,67 e 97 dias de crescimento vegetativo, encontraram valores variando entre 9,58 e $13,92 \%$ na matéria seca. Os mesmos autores (1976) ao avaliarem a influência da intensidade de murchamento sobre o teor de carboidratos solúveis do capim elefante determinaram, em média, $16,44 \%$ de carboidratos solúveis na matéria seca do capim sem murchamento, sendo que este valor diminuiu à medida que o material foi exposto ao sol por períodos crescentes.

Quanto ao poder tampão, de FARIA (1971), determinou valores de 55,26; 44,97 e 36,81 mg de ácido lático por grama de matéria seca para levar o $\mathrm{pH} \mathrm{a} \mathrm{4,0,} \mathrm{para} \mathrm{o} \mathrm{capim}$ elefante respectivamente aos 51; 86 e 121 dias de crescimento vegetativo, o que demonstra queda com o avanço da maturidade. No mesmo trabalho, o autor também pôde observar que o processo de murchamento provocou quedas significativas no poder tampão em relação à testemunha. Os valores encontrados para a forragem pré secada foram respectivamente de 37,$44 ; 35,73$ e $32,58 \mathrm{mg}$ ác. lático por grama de matéria seca aos $51 ; 86$ e 121 dias de crescimento.

Utilizando estes valores como parâmetros, pela equação de Weissbach é possível determinar o teor mínimo de matéria seca necessário no capim elefante para se obter uma silagem de boa qualidade, livre de ácido butírico:

Sendo a equação: $\quad \mathrm{Y}=45-8 \mathrm{X}, \mathrm{e} \mathrm{X}$ definido como a relação $\mathrm{Z} / \mathrm{PK}$, teremos que: 
$\mathrm{Z}=13,0 \%$ de carboidratos solúveis na M.S. - valor aproximado para idade de corte de 60 dias.

$\mathrm{PK}=55 \mathrm{mg}$ ác. lático/g matéria seca $=5,5 \mathrm{~g}$ ác. lático/ $100 \mathrm{~g}$ de mat. seca., logo, $\mathrm{Z} / \mathrm{PK}=13 / 5,5=2,36$; utilizando-se a equação:

$\mathrm{Y}=45-8 * 2,36=26,12 \%$ de matéria seca no capim para que a fermentação fosse bem sucedida.

A recomendação atual é de que o capim elefante deve ser colhido ao redor dos 60 dias de idade, o que permite que se alie produção com qualidade da forragem. Nesta fase de crescimento, o capim elefante apresenta normalmente valores inferiores a $20 \%$ de matéria seca (de FARIA, 1971 e SILVEIRA, 1976), sendo este o fator mais limitante à obtenção de silagens de boa qualidade, uma vez que pelos dados anteriormente apresentados o nível de carboidratos solúveis apresenta níveis razoáveis e o poder tampão não atinge valores limitantes. Também Knabe e Weise ${ }^{2}$ citados por LAVEZZO (1993), afirmam que um teor mínimo de matéria seca é exigido, quando a relação entre os carboidratos solúveis e o poder tampão diminui, caso contrário fermentações indesejáveis passam a ocorrer. Estes autores acrescentam que estas fermentações clostrídicas se manifestam com maior probabilidade quando as forragens são ensiladas com baixos teores de matéria seca e de carboidratos solúveis (respectivamente, inferiores a 21 e 2,2\% na matéria original). Em concordância, McCULLOUGH (1977) afirma que a fementação ideal no silo é esperada quando a forragem a ser ensilada possui de 28 a $34 \%$ de matéria seca, sendo que, nestas condições, mesmo teores de carboidratos solúveis de 6 a $8 \%$ na matéria seca seriam suficientes para desencadear fermentações láticas, desde que o poder tampão não seja elevado.

Uma vez que o capim elefante possui baixos teores de matéria seca na época de corte, e que tal fato é incompatível com a obtenção de silagens de boa qualidade, caracterizadas pela ausência de ácido butírico, amônia, e baixos $\mathrm{pH}$, é necessário que se

\footnotetext{
${ }^{2} \mathrm{KNABE}, \mathrm{H}$.O. and WEISE, G. Infulence of various factors on the fennentability of grasses. In: INTERNATIONAL GRASSLAND CONGRESS, Moscow. Proceedings...1974. v.3, p.638-663.
} 
lance mão de técnicas e/ou aditivos que reduzam a ação deletéria da umidade excessiva da planta, ou a minimizem via favorecimento de fermentações láticas nas silagens.

\subsection{Técnicas para aumentar o teor de matéria seca do capim elefante}

Diversas técnicas e aditivos têm sido estudados na confecção de silagens de capim elefante, porém até o momento, nenhuma mostrou reunir todas características desejáveis a ponto de se constituir numa prática rotineira.

Tendo como finalidade aumentar o teor de matéria seca, a primeira opção a vir em mente seria a pré secagem do material. Esta técnica foi estudada por vários pesquisadores. LAVEZZO (1993) ressalta que os resultados, às vezes conflitantes, da efetividade da técnica do emurchecimento do capim elefante, sobre a conservação e valor nutritivo das silagens, advêm das práticas experimentais adotadas. E que o fato dos pesquisadores utilizarem diferentes métodos de corte e secagem do material, aliado a estádios de desenvolvimento variados da forragem, levam a conclusões que geram questionamentos diversos sobre a possibilidade prática (e econômica) desta técnica. Como exemplo desta variação podemos citar o trabalho de MACHADO FILHO e MÜHLBACH (1986) que constataram que o aumento da matéria seca do capim elefante Cameroon, de 19,7 para 26,6\%, pelo emurchecimento, provavelmente não foi suficiente para inibir, apenas pela pressão osmótica, as bactérias clostrídicas, uma vez que os níveis de nitrogênio amoniacal (\% do $\mathrm{N}$ total) foram maiores nas silagens emurchecidas $(14,80)$ do que nas testemunhas $(9,40)$. Também é relevante o fato de que exposições ao sol por períodos muito prolongados talvez levassem a matéria seca para os níveis desejados, mas segundo SILVEIRA et al. (1973 $)$, é de se supor que o valor nutritivo da silagem fosse reduzido, pois 6 horas de murchamento provocaram reduções na digestibilidade "in vitro" da matéria seca de silagens de capim napier.

Existem ainda outros fatores que podem ser lembrados quanto à viabilidade desta técnica, como a dependência das condições climáticas, maior decomposição aeróbia por fungos e leveduras, maior custo de confecção (maior dependência de maquinaria), etc..., 
que têm feito com que a sua prática não seja muito freqüente. Disto conclui-se que a necessidade de desenvolvimento de alternativas diferentes é uma realidade.

\subsection{Aditivos na ensilagem do capim elefante}

A alternativa para o emurchecimento seria a utilização de materiais com elevado teor de matéria seca. CORSI et al. (1971) avaliaram a ensilagem de capim elefante submetido a sete diferentes tratamentos: Testemunha; $20 \%$ de fubá de milho; $15 \%$ de feno de Rhodes; $15 \%$ de palha de arroz; $15 \%$ de feno de soja perene; capim acondicionado em moenda de cana e emurchecido por 3 a 4 horas e emurchecimento ao sol por 7 a 8 horas. Todos os tratamentos alteraram a fermentação no interior do silo e inibiram o desenvolvimento das bactérias butíricas. LAVEZZO (1993) afirma que as palhadas de sorgo e soja, polpa de café, feno de capim gordura e sabugo de milho, bagaço de cana de açúcar além de outros materiais têm sido utilizados, porém, as silagens resultantes são de discutível valor nutritivo. A parte aérea da mandioca também foi testada e concorreu para a melhora da qualidade de silagens de capim elefante quando adicionada na proporção de $25 \%$ na sua forma original ou $5 \%$ na forma de farelo seco (CARVALHO 1984,1985). O problema seria a disponibilidade deste material, que não é comum nas propriedades, principalmente na região sul e sudeste do país, o que a torna pouco viável como alternativa.

Outra possibilidade é a adição de cama de frango, que segundo LAVEZZO e CAMPOS $(1977,1978)$ apresentou bons resultados, quando níveis crescentes variando de 5 a $25 \%$, aumentaram linearmente os teores de matéria seca das silagens, elevando também os teores de proteína bruta, porém dificultando a queda do $\mathrm{pH}$ e com tendência de diminuição dos teores de ácido lático. Segundo os autores esse material aumentou linearmente a digestibilidade "in vitro" das silagens, tendo contribuído também para aumentar os ganhos de peso e consumo de matéria seca por unidade de peso metabólico 
de bovinos. Por outro lado Avila ${ }^{3}$ et al., citados por LAVEZZO (1993) recomendam que a cama e esterco de frango sejam armazenados por 35 a 40 dias, para que possam fermentar, evitando assim a transmissão de doenças como a salmonelose, o botulismo, etc... embora o trabalho de OLIVEIRA et al. (1988) demonstre que semelhante tempo de estocagem pode alterar a composição bromatológica do produto, o que deve ser levado em consideração por ocasião de sua utilização.

Uma técnica altemativa sob o ponto de vista de garantir uma boa fermentação do capim elefante é o uso de aditivos. McDONALD (1981), classificou os aditivos em: a) estimulantes da fermentação (culturas bacterianas e fontes de carboidratos); b) inibidores da fermentação (ácidos e outros); c) inibidores da deterioração aeróbia e d) nutrientes, sendo que muitas substâncias relacionadas como fontes de carboidratos podem ser relacionadas nesta última categoria.

Em revisão da literatura, LAVEZZO (1993), mostrou que as culturas bacterianas geralmente apresentam efeito positivo apenas quando o capim é ensilado com mais de $20 \%$ de matéria seca. Além disso, os resultados até então obtidos não permitem uma posição consciente para o técnico quanto à preconização geral desses aditivos, sem se considerar seu custo, normalmente elevado.

Como fontes de carboidratos que auxiliarão na fermentação, os materiais mais freqüentemente utilizados são a cana-de-açúcar, o melaço, o milho e a mandioca. A canade-açúcar tem propiciado melhoras no processo fermentativo, todavia, segundo LAVEZZO (1993) o valor nutritivo destas silagens tem deixado a desejar. Além disso, TOSI (1973) atribuiu a dificuldade de implementação desta técnica ao fato de que na época da ensilagem do capim elefante, é difícil a obtenção da cana na sua forma madura, e quando nova, o excessivo teor de umidade e baixo teor de açúcar, não permitem o incremento da fermentação no silo. $\mathrm{O}$ melaço de cana-de-açúcar também já foi testado e os resultados demonstram, de modo geral um efeito benéfico ao processo fermentativo

\footnotetext{
${ }^{3}$ AVILA , F.A.; SILVA, E.N.; FERREIRA, M.D. Isolamento e identificação de salmonella em cama de aviário nos arredores de Belo Horizonte. Arquivos da Escola de Veterinária da Universidade Federal de Minas Gerais, B.H. 1972. 24(3):p.227-229.
} 


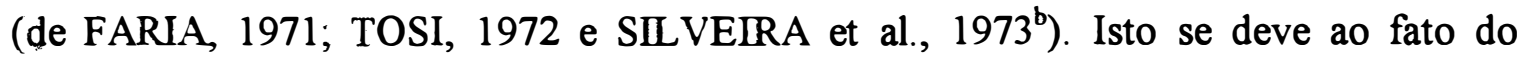
melaço apresentar elevados teores de carboidratos solúveis. Este produto provavelmente não ganhou popularidade em função da dificuldade de sua aplicação, que em função de sua alta viscosidade, requer a diluição em água quente, a fim de que maior volume seja adicionado sem que ocorram perdas por drenagem. Além disto, a disponibilidade do produto e seu preço na maioria dos casos inviabilizam a sua utilização.

O milho e a mandioca têm sido utilizados com freqüência na ensilagem do capim elefante. $\mathrm{O}$ milho foi utilizado na forma de planta inteira, conforme mostra o trabalho de FERREIRA et al. (1988), que conseguiram melhora na qualidade da silagem de capim Cameroon, quando adicionou a planta de milho no estágio de grãos pastosos/farináceos nas proporções de 2:1 e 1:2. A maneira mais comum de utilização deste cereal no entanto é sob a forma de rolão (espiga triturada inteira com palha e sabugo), grãos triturados e fubá.

O rolão de milho foi utilizado por EVANGELISTA et. al. (1987), que verificaram que este material aumentou o consumo de matéria seca das silagens de capim elefante, e concluíram que os níveis de 4 e $6 \%$ propiciaram os melhores resultados, principalmente quando associados ao capim novo. $\mathrm{O}$ rolão, além de aumentar a disponibilidade de açúcares fermentecíveis, propicia a elevação do teor de matéria seca do material armazenado.

É sob a forma de fubá que o milho tem sido utilizado com maior frequêencia. Os resultados das pesquisas têm sido inconsistentes e isto provavelmente se deve ao fato de que o principal carboidrato do milho é o amido, e segundo McDONALD e WHITTENBURY (1973), este polissacarídeo não é fermentado pelas bactérias láticas. LAVEZZO (1993) afirma que "o fubá, como aditivo de silagens de capim elefante, não tem propiciado resultados uniformes no que concerne a melhoria da fermentação no interior do silo, nem tampouco sobre o desempenho animal; porém, quer por sua ação elevando o teor de matéria seca da gramínea ensilada, favorecendo, portanto, indiretamente a fermentação, quer por elevar o valor energético da silagem como alimento, é recomendável a sua adição". Para comprovar esta teoria, podemos citar o 
trabalho de CORSI et. al. (1971), no qual a a adição de $20 \%$ de fubá ao capim elefante, foi capaz de alterar a fermentação, praticamente inibindo o desenvolvimento de bactérias butíricas nas silagens, provavelmente pela elevação no teor de matéria seca.

A utilização da mandioca, normalmente sob a forma de raspas, de forma semelhante ao milho, parece não contribuir como fonte de carboidratos para a fermentação, pois, segundo Godoy, citado por FARIAS e GOMIDE (1973), 75,7\% dela são constituídos por amido. Todavia, estudos conduzidos por estes autores através da adição de $75 \mathrm{~kg}$ de raspas de mandioca por tonelada de matéria verde, em material previamente emurchecido, elevou os teores de matéria seca das silagens, carboidratos solúveis e digestibilidade "in vitro" da matéria seca das silagens, muito embora, no mesmo estudo, a mandioca não tenha se revelado uma boa fonte de carboidratos facilmente fermentecíveis pelos Lactobacillus.

\subsection{A polpa de citros}

Como pode ser observado, até o presente momento nada foi mencionado em relação à polpa de laranja, objetivo principal desta pesquisa. Isto ocorreu por dois motivos: o primeiro é que a literatura é escassa neste assunto, existindo poucos estudos que utilizaram a polpa fresca como aditivo na ensilagem, e apenas foi encontrado um trabalho, na literatura nacional, no qual foi avaliado o efeito da adição de polpa seca na ensilagem do capim elefante (de FARIA et al., 1972). O segundo motivo é a intenção de demonstrar que a principal limitação do capim elefante à ensilagem é o seu teor de matéria seca, e que um aditivo ideal deveria reunir como características um alto teor de matéria seca, alta capacidade de absorver água, alto valor nutritivo, boa palatabilidade, elevado teor de carboidratos solúveis, fácil manipulação, boa disponibilidade de mercado e baixo custo de aquisição. De acordo com o que foi colocado durante esta revisão, nenhum dos materiais mencionados se enquadram perfeitamente nestas condições. No entanto, a polpa de citros seca e peletizada, parece encaixar de maneira precisa em todos 
os requisitos, constituindo-se portanto no suplemento ideal para viabilização da ensilagem do capim elefante.

Muito embora a polpa de citros venha sendo utilizada na nutrição de ruminantes desde 1911 (WING, 1982), pouca informação existe sobre a sua utilização como aditivo de silagens. As poucas referências existentes limitam-se ao uso da polpa fresca, que nas nossas condições não pode ser comercializada em função de proibições legais que visam o controle do cancro cítrico.

No Brasil, a produção de polpa seca e peletizada chega a 1.300 .000 toneladas por ano, mas o consumo de polpa cítrica é ainda muito baixo, uma vez que a sua quase totalidade tem como mercado consumidor a Europa. AMARO (1978), afirmava que a polpa de citros se tratava de um produto ainda desconhecido dos produtores nacionais, muito embora as fábricas de ração já tivessem demonstrado interesse em adquirir o produto. Nos últimos quatro anos, porém, esta situação se alterou, devido ao interesse de algumas esmagadoras de laranja em desenvolver o mercado interno, ao que se alia um intenso trabalho de divulgação desenvolvido por alguns técnicos e revistas especializadas de circulação nacional. Existem evidências de que, dentro de alguns anos, a Comunidade Econômica Européia poderá deixar de importar polpa de citros, gerando um problema até então inexistente para as fábricas esmagadoras de laranja (CARFANTAN, 1993). O produto concorre com cereais e subprodutos locais, como a polpa de beterraba, e em função do excesso de produção de grãos e da diminuição dos rebanhos por regulamentações ambientais, a sua demanda poderá ser reduzida no exterior. Desta forma, um melhor entendimento das potencialidades deste produto parece ser bastante conveniente no momento, pois existe uma tendência de abertura do mercado para o produtor nacional.

\subsubsection{Valor nutritivo}

A polpa de citros seca e peletizada possui elevado teor de matéria seca (89-90\%) e alta capacidade de absorção de água. WING (1982) sugere valores de até $145 \%$ do seu 
peso em absorção de efluentes, contendo valiosos nutrientes, que de outra maneira seriam lixiviados do silo. Segundo Becker ${ }^{4}$ et al., citados por WING (1982), a absorção de efluentes aumentou com incrementos em polpa de citros até o nível de adição de $11 \%$, quando utilizada como aditivo na ensilagem de gramíneas e ele sugere a sua adição em níveis de $7 \%$ na matéria original, uma vez que a partir deste valor os incrementos na absorção diminuíram rapidamente.

Quanto ao valor nutritivo, a análise bromatológica nos permite afirmar que a polpa cítrica apresenta $90-95 \%$ do valor energético do milho (N.R.C., 1989). Diversos trabalhos demonstram que o milho pode ser substituído pela polpa cítrica sem prejuízo para o desempenho dos animais, devendo sua inclusão na dieta ser feita, no geral, em função de sua economicidade e composição dos demais ingredientes (WING, 1982). LUCCI et al. (1975), num dos poucos experimentos em território nacional, substituíram até $100 \%$ do milho rolão por polpa de citros em dietas de vacas em lactação de baixa produção, sendo que esta chegou a constituir $67 \%$ do concentrado formulado. Os autores obtiveram aumento do teor de gordura e da produção de leite corrigida para gordura (12,6 para 13,2 kg/vaca/dia). A conclusão foi que a polpa de citros pode substituir totalmente o milho desintegrado em dietas de vacas em lactação, sendo a extensão desta substituição apenas função do preço dos ingredientes.

Também VAN HORN et al., (1974), trabalhando com vacas em lactação em dietas à base de bagaço de cana (25\%), estudaram o valor nutricional da polpa de citros na produção de leite em comparação ao milho. As dietas continham $8 \%$ ou $43 \%$ de polpa de citros na matéria seca total. Os resultados do trabalho, demonstraram que houve elevação do teor de gordura e dos sólidos não gordurosos do leite, bem como da produção de leite corrigida para o teor de sólidos na dieta com $43 \%$ de polpa de citros. Outros autores encontraram ainda aumento da digestibilidade da fração fibrosa da dieta quando a polpa de citros substituiu o milho na dieta de carneiros (BHATTACHARYA e HARB, 1973).

\footnotetext{
${ }^{4}$ BECKER, R.B.; WING, J.M.; ANROLD, J.T.; McCALL, J.T. and WILCOX, C.J. Silage investigations
} in Florida. Fla. Agr. Exp. Sta. Bull. 734. 1970. 
Mais recentemente, em experimento conduzido com vacas em lactação, na granja demonstrativa e experimental de bovinos de leite da Cooperativa Central de Laticínios do Paraná (CCLPL), no intuito de comparar a polpa cítrica à silagem de grãos de milho úmido (KOSSOSKI, 1993), constatou-se que a produção de leite e o teor de gordura foram superiores no grupo que recebeu a polpa de citros $(32,06 \mathrm{~kg}$ de leite e $3,2 \%$ de gordura para o tratamento com polpa, contra $30,55 \mathrm{~kg}$ de leite e $2,86 \%$ de gordura para o tratamento com milho úmido). Consequentemente, a produção corrigida para $3,5 \%$ de gordura também foi superior no tratamento com polpa cítrica.

\subsubsection{Palatabilidade}

Em relação à palatabilidade, HARRIS (1975), afirma que os pecuaristas de leite da Flórida vêm usando a polpa de citros já há 60 anos e consideram-na um alimento bastante palatável, sendo fornecida separadamente ou misturada a outros ingredientes na ração completa. $\mathrm{O}$ mesmo autor considera que níveis de até $40 \%$ na matéria seca total da dieta de vacas em lactação não causam problemas de consumo.

Trabalhando com bovinos de corte, GOHL (1971), afirma que além de ser excelente fornecedora de energia, a polpa de citros é palatabilizante e exerce leve efeito laxante nos animais. NEAL et al. (1935) elaboraram um experimento para testar a palatabilidade da polpa cítrica seca para vacas em lactação. De 31 vacas, apenas uma recusou a polpa cítrica (oferecida a $0,5 \mathrm{~kg} / \mathrm{dia}$ ) quando fornecida separadamente, após as refeições, por um período de 6 dias. $\mathrm{O}$ apetite dos animais cresceu gradativamente.

\subsubsection{Perfil e caracterísitcas dos carboidratos}

Outro fator favorável em relação à polpa de citros é o seu elevado teor de carboidratos solúveis, essenciais para a rápida acidificação do meio e conservação do produto ensilado. Segundo de FARIA et al. (1972), a análise da polpa desidratada revelou valores de $26 \%$ de carboidratos solúveis, valor este considerado bastante alto. 
Mas o que parece fazer da polpa de laranja um alimento realmente distinto, é seu alto teor de pectina ( $25 \%$ na matéria seca), um carboidrato estrutural, que segundo HALL (1995), possui algumas particularidades que o torna um desafio com potenciais beneficios para o balanceamento de dietas de ruminantes.

A pectina faz parte da parede celular, muito embora, nas análises bromatológicas, normalmente seja incluída entre os carboidratos não estruturais, como os açúcares e amidos, já que é solúvel em solução de detergente neutro. Isto se deve ao fato de que, de forma não usual, a pectina se comporta como um carboidrato não estrutural, tendo rápida e extensiva degradação pelos microorganismos do rúmen, muito embora quando se trata de produtos finais da fermentação, se assemelhe aos carboidratos estruturais, parecendo não contribuir para o abaixamento do $\mathrm{pH}$ ruminal ou acidose lática. Segundo VAN SOEST (1987), estas carcterísticas somadas ao fato de que a própria natureza estrutural do ácido galacturônico, que fornece um potencial tamponamento ao meio, através de sua alta capacidade de troca de cátions e ligações com íons metálicos, "explicam parte do efeito "mágico" quando alimentos contendo pectina são utilizados em substituição do amido em dietas com alta concentração deste carboidrato".

Um trabalho que exemplifica parte destes conceitos foi conduzido por CHESSON e MONRO (1982), no qual a pectina foi digerida a taxas de 30 a $45 \%$ por hora, tendo sua quase completa degradação em 12 ou 18 horas. Quanto à digestibilidade aparente, GAILLARD (1962), determinou valores maiores que 90\% para a pectina em capim fresco, alfafa e trevo. Ainda num estudo de BEN-GHEDALIA et al. (1989), a pectina da polpa de citros e feno de alfafa, utilizados numa dieta oferecida a carneiros, e medida na forma de ácidos urônicos de pectina, apresentou digestibilidade de $96,6 \%$ no rúmen e $98,7 \%$ no trato digestivo total, e no que se refere aos produtos finais da fermentação, este autor determinou maior proporção de ácido acético, e maior $\mathrm{pH}$ quando a dieta rica em pectina foi comparada com outra rica em amido. Em concordância, Hatfield ${ }^{5}$ et al., citados por HALL (1995) e também STROBEL e RUSSEL (1986), demonstraram que a

\footnotetext{
${ }^{5}$ HATFIELD, RD. and WEIMER, P.J. Characterization of the degradative pattern of alfalfa pectins by rumen microbes. U.S. Dairy Forage Research Center, Research Sumamaries p.75. 1991.
} 
fermentação "in vitro" da pectina proporcionou aumento do acetado e em complementação, os últimos autores ainda não detectaram formação de lactato durante o processo.

Esta característica da pectina, e por extensão de alguns alimentos que a contém em alta concentração, de fermentar rápida e extensivamente, parece propiciar um efeito associativo positivo, quando estes alimentos são utilizados em substituição à forragens de baixa qualidade. Isto foi observado por diversos pesquisadores. Para exemplificar podemos citar HIGHFILL et al. (1987), que comparou dietas à base de feno de gramínea suplementadas com milho (95\%) + farelo de soja (5\%); casca de soja; farelo de gluten de milho ou polpa de citros $(87 \%)+$ far. de soja $(12,5 \%)$. Embora a digestibilidade da matéria seca no trato digestivo total não tenha apresentado diferença estatística, os resultados monstraram que a polpa de citros estimulou a fermentação ruminal, avaliada através da recuperação de matéria orgânica e proteína microbiana, especialmente quando comparada ao suplemento que teve por base o milho. $\mathrm{O}$ autor afirma que suplementos energéticos fibrosos são preferenciais aos amiláceos na suplementação de forragens de baixa qualidade por diminuirem a possibilidade de alteração na flora ruminal, uma vez que em sua fermentação se comportam como carboidratos estruturais. Este efeito associativo positivo também foi destacado por WING (1982), em sua revisão, utilizando como exemplo um trabalho do qual foi co-autor (SCHAIBLY e WING, 1974), onde a polpa de citros foi testada substituindo $0 ; 1 / 3 ; 2 / 3$ e toda silagem de milho fornecida a novilhas. Pelos resultados, a digestibilidade da matéria seca e da energia aumentaram até o nível de $2 / 3$ de polpa de citros, mas não acima disso. Em complementação, a digestibilidade da proteína só diminuiu no tratamento com substituição total da silagem . WING (1982), afirma ainda que a polpa de citros isoladamente é uma fonte ruim de proteína, porém quando combinada com a silagem de milho parece ser adequada em relação a este nutriente, além desta associação permitir maior eficiência na utilização da energia da 
dieta, conforme também já havia sido sugerido por Keener ${ }^{6}$ et al., citados por WING, 1982.

Por apresentar este comportamento similar aos componentes da parede celular, no que se refere aos produtos finais de fermentação, a pectina tem sua degradação influenciada pelo $\mathrm{pH}$ ruminal. No ensaio de fermentação "in vitro" conduzido por STROBEL e RUSSSEL (1986), a utilização da pectina pelos microorganismos caiu 59\% e a síntese de proteína bacteriana caiu $69 \%$ quando o $\mathrm{pH}$ ajustado do meio caiu de 6,7 para 6,0 .

Outro ponto de interesse, é que parece não ter sido provado, até o momento, qualquer ligação entre a pectina e a lignina, mesmo com o aumento da maturidade da planta (HALL, 1995). Em relação a isto, JUNG et al. (1992) concluíram que a extensão da digestão da pectina parece não ser afetada pela lignificação na alfafa e colmo de milho. De qualquer forma, se tratando de polpa de citros, o teor de lignina é bastante baixo (cerca de 1,0\% de acordo com o NRC, 1989).

Embora possua todas estas caracterísitcas desejáveis, a pectina ainda é um carboidrato pouco entendido devido à falta de uma metodologia simples, rápida, eficiente e econômica para sua determinação. Segundo HALL (1995), não existe ainda uma análise química direta e única, que permita a determinação da pectina nos alimentos. $\mathrm{O}$ motivo para isto parece ser a composição bastante diversa, e com vários açúcares desta fração, e que alguns destes açúcares também são encontrados em frações menos digestíveis da parede celular, além do fato que outros componentes da parede celular são suficientemente similares ao ácido galacturônico a ponto de interferir na sua análise direta nos alimentos.

HALL (1995), argumenta ainda que "à parte das dificuldades com sua análise, a maior preocupação com a pectina é pela contaminação de outras frações da fibra". Isto porque conforme já comentado, a pectina é largamente extraída pela solução de

\footnotetext{
${ }^{6}$ KEENER, H.A.; COLOVOS, N.F. and ECKBERG, R.B. The nutritive value and nutritive properties of citros by-products. 1. The digestible nutrients of dried grapefnit refuse for growing heifers. Fla. Agr. Exp. Sta. Bul. 275. 1957.
} 
detergente neutro, juntamente com os carboidratos não estruturais, porém, a solução de detergente ácido não a extrai completamente, o que pode significar uma significativa contaminação desta fração. Em outras palavras, um dos carboidratos mais digestíveis (pectina) estaria aumentando o valor de uma fração menos digestível (fibra em detergente ácido). Para solucionar o problema, Robertson ${ }^{7}$, citado por HALL (1995), recomenda a análise sequencial entre detergente neutro e detergente ácido como única alternativa para solucionar tal problema.

\subsubsection{A polpa de citros e o processo de ensilagem}

Cabe ressaltar que a pectina difere dos carboidratos não estruturais quanto ao seu destino durante a ensilagem. Nesta situação, quase todos os açúcares da fração carboidrato não estrutural e parte do amido são fermentados. Já a pectina (avaliada na forma de ácidos urônicos pécticos) permaneceu intacta após 90 dias de fermentação (BEN-GUEDALIA et al., 1991). Neste caso, portanto, este carboidrato seria preservado para a fermentação direta pelos microorganismos do rúmen, o que parece ser energeticamente mais eficiente.

No Brasil só existe um trabalho estudando a polpa fresca ou seca como aditivo de silagens de capim elefante, de autoria de FARIA et al. (1972), que adicionaram níveis crescentes de polpa de citros seca $(0 ; 5 ; 10 ; 15$ e $20 \%$ na matéria original do capim), ou ainda $20,30,40$ e 50\% de polpa úmida na matéria original, e concluíram que a polpa de laranja tanto fresca quanto dessecada podem ser consideradas como bons aditivos para a ensilagem do capim napier pois além de aumentarem os teores de carboidratos solúveis do material, reduziram o $\mathrm{pH}$ das silagens. Muito embora não tenham sido conduzidos ensaios de digestibilidade, os autores sugerem que este tratamento poderia trazer outros beneficios ao capim a ser ensilado em função de sua característica energética. $\mathrm{Na}$ época, a idéia foi abandonada em função do preço da polpa seca que tinha mercado certo na comunidade européia. Também McCULLOUGH et al. (1960), utilizaram a polpa de

\footnotetext{
${ }^{7}$ ROBERTSON, J.B. The detergent system of fiber analysis. In: Topics in dietary fiber research. G.A. Spiller, ed. Plenum Press, New York. 1978.
} 
citros seca $(90 \mathrm{~kg} / \mathrm{ton})$ como aditivo à ensilagem da alfafa, em comparação a diversos outros aditivos. Eles conlcuíram que as silagens foram bem preservadas, podendo ser classificadas como boas a excelentes, sendo que a polpa de citros só foi superada pelo grão de milho moído como aditivo, no que se refere à preservação da massa e recuperação de nutrientes, uma vez que o milho propiciou padrão de fermentação mais uniforme, com menor perda de carboidratos solúveis, muito embora a fermentação nos silos aditivados com polpa tenha sido mais rápida. As silagens aditivadas com polpa, no entanto, quando fornecidas a animais em lactação, apresentaram melhores resultados, avaliados na forma de consumo de matéria seca, ganho de peso e produção de leite corrigido para $4 \%$ de gordura.

A manipulação da polpa de citros é muito fácil uma vez que toda a produção é comercializada na forma seca e peletizada, o que permite fácil mistura e homogeneização com outros materiais. $\mathrm{O}$ produto encontra-se disponível no mercado no período que compreende os meses de maio a janeiro, que corresponde ao período de safra da laranja. Este período coincide com grande parte do período de produção de forragens, existindo ainda a possibilidade de estocagem do material a granel, em silos graneleiros ou ainda em armazéns, através do ensacamento.

Em função destas características que foi levantada a hipótese da aditivação do capim elefante com a polpa de citros, pois esta viria a suprir exatamente os fatores limitantes encontrados nesta forragem. Uma vez que o único trabalho existente não avaliou a digestibilidade do produto final, tampouco o comparou à silagem de milho, sua possível substituta, acreditamos ser este o momento propício para realização de tal trabalho. 


\section{MATERIAL MÉTODOS}

O trabalho foi conduzido no Departamento de Zootecnia - Setor de Ruminantes, da Escola Superior de Agricultura "Luiz de Queiroz", da Universidade de São Paulo, no município de Piracicaba - S.P., situado a $22^{\circ} 45^{\prime}$ de latitude sul, e $47^{\circ} 38^{\prime}$ de longitude oeste a uma altitude de $537 \mathrm{~m}$.

A avaliação do efeito da adição de polpa de citros à ensilagem do capim napier foi realizada em duas fases. Na primeira fase, foi avaliado seu efeito na conservação da silagem de capim elefante. Foram utilizados 25 silos experimentais com capacidade de 1,33 litros, confeccionados em tubos de PVC de 4 polegadas de diâmetro, com tampas nas extremidades e um orificio na extremidade inferior, dotado de rolha, que permitiu a coleta do efluente e posterior vedação do mesmo para impedir a entrada de ar no sistema entre os períodos de coleta. Cada tratamento teve 5 repetições. A segunda fase consistiu de um ensaio de digestibilidade, em carneiros, para o qual maior quantidade foi conservada no interior de latões de 2001 . Foram utilizados 6 carneiros.

O capim elefante utilizado (Penissetun purpureum Schum. - cultivar Roxo Botucatu) foi obtido na Fazenda Tainá, no município de São Pedro, e quando foi cortado, no dia 03 de abril de 1995, tinha 72 dias de crescimento. A área é regularmente utilizada como capineira, o que permitiu rápida colheita através de uma ensiladeira. $\mathrm{O}$ capim foi colhido no período da manhã, entre 9:00 e 10:00 hs, e foi transportado até as dependências da escola em Piracicaba por caminhão. Chegando ao local do experimento este material foi descarregado no chão sobre uma lona plástica, em local sombreado. Por volta das 13:00 h teve início o processo de ensilagem, que durou até as 20:00 h. Devido à longa duração do processo, ao final do dia parte do capim que ainda restava já apresentava sinais de deterioração (aquecimento), motivo pelo qual foi descartado.

No processo de ensilagem o capim era pesado em várias porções, às quais se adicionavam e misturavam as quantidades necessárias de aditivos, com base na matéria verde, em função dos tratamentos. Os mesmos foram constituídos de forma alternada e aleatória, em pequenas porções, ou seja, foi ensilada uma parte da testemunha, seguida de 
uma parte do tratamento com $5 \%$ de polpa, e assim sucessivamente, até que todos os tratamentos tivessem quantidades semelhantes preparadas. Neste ponto se retomava a ensilagem da testemunha e o ciclo era iniciado novamente. Este procedimento teve por finalidade imprimir maior aleatoriedade ao experimento e evitar a falta de material para confecção de algum dos tratamentos no final do processo. Das mesmas porções utilizadas para ensilagem nos latões, foi retirado o material utilizado nos silos de PVC. Estes últimos foram previamente tarados e pesados após seu enchimento. Também foram retiradas amostras do material anteriormente à ensilagem.

A polpa de citros foi adicionada, na base da matéria verde, na forma em que se encontra disponivel no mercado, ou seja, peletizada, pois a intenção era que nenhum processamento fosse necessário, evitando-se maior necessidade de mão de obra e incrementos no custo do processo. $\mathrm{O}$ milho foi adicionado na forma de fubá. 


\subsection{Ensaio de conservação em silos experimentais}

\subsubsection{Tratamentos e delineamento}

Abaixo encontra-se uma lista dos tratamentos constituídos e da nomenclatura que será utilizada a partir daqui para identificá-los:

Denominação: Descrição:

T - $0 \quad$ Silagem de capim napier, sem aditivos (testemunha)

T - 5 Sil. de capim napier $+5 \%$ de polpa cítrica (na matéria original)

T - 10 Sil de capim napier $+10 \%$ de polpa cítrica (na matéria original)

T - 15 Sil. de capim napier $+15 \%$ de polpa cítrica (na matéria original)

T - M Sil. de capim napier $+10 \%$ fubá de milho (na matéria original)

Estes níveis de inclusão foram escolhidos em função dos cálculos realizados a partir da equação de WEISSBACH et al. (1974), anteriormente discutida, para que se chegasse a valores satisfatórios de matéria seca e carboidratos solúveis, permitindo assim a obtenção de silagens de boa qualidade. Para os cálculos foram adotados os seguintes parâmetros, obtidos na literatura:

Capim Elefante: $18 \%$ de matéria seca

$12 \%$ de carboidratos solúveis em água, na matéria seca.

Poder tampão $=5,52 \mathrm{~g}$ de ác. lático/ $100 \mathrm{~g}$ de M.S.

Polpa de Citros: $90 \%$ de matéria seca

$26 \%$ de carboidratos solúveis em água, na matéria seca 
O quadro abaixo demonstra os cálculos realizados:

\begin{tabular}{|l|r|r|r|r|r|}
\hline & \multicolumn{1}{|c|}{$\begin{array}{c}\mathrm{T}-0 \\
\text { testemunha }\end{array}$} & $\begin{array}{c}\mathrm{T}-5 \\
5 \% \text { polpa }\end{array}$ & $\begin{array}{r}\mathrm{T}-10 \\
10 \% \text { polpa }\end{array}$ & $\begin{array}{r}\mathrm{T}-15 \\
15 \% \text { polpa }\end{array}$ & $\begin{array}{r}\mathrm{T}-\mathrm{M} \\
10 \% \text { fubá }\end{array}$ \\
\hline | & 100 & 95 & 90 & 85 & 90 \\
\hline Polpa kg MO/t & - & 5 & 10 & 15 & - \\
\hline Milho kg MO/t & - & - & - & - & 10 \\
\hline Elef. kg MS/t & 18 & 17,1 & 16,2 & 15,3 & 16,2 \\
\hline Polpa kg MS/t & - & 4,5 & 9 & 13,5 & -1 \\
\hline Milho kg MS/t & - & - & - & - & 8,8 \\
\hline Valores calculados & $18 \%$ & $21,6 \%$ & $25,2 \%$ & $28,8 \%$ & $25,0 \%$ \\
\hline \% MS esperada & $12 \%$ & $14,9 \%$ & $17,0 \%$ & $18,56 \%$ & \\
\hline \%Carb. solúvel-MS & $5,5 \mathrm{~g} / 100 \mathrm{~g}$ & & & & \\
\hline Poder tampão & 2,18 & 2,71 & 3,09 & 3,37 & \\
\hline Z/PK & 27,6 & 23,3 & 20,3 & 18,0 & \\
\hline $\begin{array}{l}\text { \%MS mínima neces- } \\
\text { sária pela equação: }\end{array}$ & & & & & \\
\hline
\end{tabular}

Como pode ser observado pelo quadro, com a adição de $10 \%$ de polpa de citros já seria possível a obtenção de silagens de boa qualidade, uma vez que o teor de carboidratos solúveis obtido com a adição permitiria que mesmo com teor de matéria seca de $20,3 \%$ a fermentação fosse bem sucedida. Optou-se a partir daí pelo tratamento com $15 \%$ de polpa, por motivo de segurança (o teor de matéria seca é mais apropriado) e pelo tratamento com $10 \%$ de milho como termo de comparação com aquele que seria o tratamento limite para o sucesso da ensilagem com a polpa.

\subsubsection{Período experimental}

Passados 42 dias da ensilagem, os silos de laboratório (PVC) foram abertos. 


\subsubsection{Coleta de amostras}

Nos dias que se seguiram à ensilagem, foi coletado o efluente dos silos experimentais diariamente, através do orificio existente na base do silo de PVC. Esta coleta foi realizada através de pressão exercida sobre o silo, sem todavia que se tivesse controle da força exercida. A pressão era exercida na forma do peso do corpo sobre a tampa do silo, até que esta não mais sofresse deslocamento. $O$ volume do efluente coletado era determinado. Este material foi imediatamente congelado.

O material foi pesado em sua totalidade, no momento da ensilagem e no momento da abertura dos silos, para que fosse possível o cálculo da recuperação de matéria seca no produto final, através da relação entre o peso seco da silagem obtida e o peso seco do material verde ensilado, devidamente descontados a tara dos silos em ambos os casos. No momento da ensilagem também foram constituídas amostras do material fresco, para posterior análise do teor de carboidratos solúveis e poder tampão.

A porção superior do material, que se encontrava deteriorada foi descartada após a pesagem. Do material restante, aproximadamente $1 / 3$ foi prensado para obtenção do suco, de onde foi avaliado o $\mathrm{pH}$ e parte foi congelada para posterior análise dos ácidos graxos voláteis. Outra porção foi seca em estufa, para determinação da matéria seca e realização da análise do poder tampão. Uma terceira porção foi congelada e posteriormente analisada quanto aos teores de nitrogênio amoniacal e carboidratos solúveis. O material anterior à ensilagem também foi seco em estufa para avaliação da recuperação da matéria seca. 


\subsubsection{Análises químicas}

Para avaliação da eficácia na conservação da silagem, foram analisados os seguintes parâmetros, no material proveniente dos silos experimentais:

$-\mathrm{pH}$

- Matéria Seca

- Nitrogênio Amoniacal

- Ácidos Graxos Voláteis (Acético; Propiônico e Butírico)

No material coletado antes da ensilagem também foram realizadas as seguintes análises:

- Carboidratos Solúveis

- Poder Tampão

As determinações de matéria seca e nitrogênio amoniacal foram feitas de acordo com os métodos da A.O.A.C. (1975).

Os carboidratos solúveis foram determinados pelo método do fenolsulfúrico descrito por JOHNSON et. al. (1967).

O poder tampão foi determinado pelo método de McDONALD e HENDERSON (1962).

Os ácidos graxos voláteis foram determinados pelo método descrito por ERWIN et al. (1961).

\subsubsection{Análises físicas}

- Volume do efluente 


\subsubsection{Análise estatística}

O experimento foi analisado na forma de um modelo inteiramente ao acaso, como segue:

\begin{tabular}{|l|c|}
\hline Causa da Variação & Graus de Liberdade \\
\hline - Tratamentos & 4 \\
\hline - Resíduo & 20 \\
\hline - Total & 24 \\
\hline
\end{tabular}

A análise da variância foi realizada pelo procedimento GLM do Sistema de Análise Estatística (SAS), e as diferenças entre as médias foi feita pelo teste de Duncan.

Após a realização de uma análise exploratória em todas as variáveis, através do procedimento LAB do SAS, concluiu-se que as variáveis matéria seca, ácido butírico e ácido propiônico apresentavam problemas de "outliers" e de escala. Entretanto, pela transformação Box-Cox, que sugeriu as potências $(-3),(0,1)$ e $(-0,3)$, respectivamente para a transformação da matéria seca, ác. propiônico e ác. butírico, os problemas foram resolvidos.

\subsection{Ensaio de digestibilidade "in vivo" em carneiros}

\subsubsection{Tratamentos e delineamento}

Além dos tratamentos já descritos na fase I, para o ensaio de digestibilidade foi acrescentado um tratamento denominado $\mathbf{T}-\mathbf{S}$, que consistia de silagem de milho, disponível no departamento, que semelhante às silagens de capim confeccionadas já se encontrava armazenada em latões de 200 litros. Esta silagem não possuía qualquer tipo de aditivo. Para uma silagem de milho, pode ser considerada com baixo teor de matéria seca ( $25 \%$ M.S.), por outro lado é um bom termo de comparação pois encontra-se numa faixa próxima aos tratamentos com maior proporção de aditivos. 
A idéia inicial era se constituir um quadrado latino $5 \times 5$. Em face da inclusão do tratamento referente à silagem de milho, foi necessário a inclusão de um sexto carneiro, $\mathrm{e}$ deveriam ter sido realizados, consequentemente, 6 períodos experimentais. Isto todavia não foi possível, devido a insuficiência de material (silagem), em vários tratamentos. Foram mantidos, portanto, os 5 períodos originais (com 6 tratamentos e 6 carneiros), e a análise estatística foi realizada na forma de um delineamento em quadrado latino incompleto. Com isto perdeu-se o controle sobre a fonte de variação período.

\subsubsection{Animais e instalações}

No ensaio de digestibilidade foram utilizados 6 carneiros da raça corriedale, machos, castrados, com idade média de 18 meses, peso médio de $50 \mathrm{~kg}$. Os animais foram pesados nos três dias iniciais de cada subperíodo experimental. No início do experimento foram tosquiados, tratados com vermífugo, identificados e confinados em gaiolas metabólicas, que foram equipadas com bebedouros e cochos para fornecimento do alimento. Os animais só foram retirados das gaiolas para as pesagens periódicas, permanecendo confinados durante todo o restante do período experimental.

\subsubsection{Período experimental}

O capim foi ensilado conjuntamente com os silos de laboratório, da fase I, porém sua utilização só teve início no mês de junho e foi concluída no mês de outubro.

Em cada período os animais passaram por uma fase de adaptação de 14 dias, e uma coleta de 7 dias.

Após o término da coleta de cada subperíodo ocorreu o rodízio dos tratamentos entre os carneiros, conforme estabelecido pelo delineamento utilizado. 


\subsubsection{Dietas e coletas de amostras}

As dietas foram constituídas unicamente das respectivas silagens obtidas em cada tratamento e foram fornecidas diariamente aos animais, divididas em 2 refeições às 8:00 e 18:00 horas. Os animais receberam sal mineral e água a vontade durante o período experimental.

No período de adaptação foi avaliado o consumo de matéria seca, para ajustar a oferta no período de coleta, quando foram fornecidos $90 \%$ do consumo voluntário médio observado. Para tal, amostras dos diferentes tratamentos foram coletadas semanalmente para determinação da matéria seca do material. A partir do décimo dia deu-se inicio ao ajuste e regularização do consumo, através de restrição alimentar, que garantia o consumo de todo material oferecido, evitando assim a necessidade de análise das sobras.

Os sete últimos dias de cada subperíodo corresponderam ao período de coleta individual. Nesta fase foram feitas amostragens das silagens oferecidas (duas vezes ao dia, no momento das refeições, com início 2 dias antes do início da coleta de fezes e final 2 dias antes do final do período de coleta de fezes), bem como das fezes e da urina (uma vez ao dia às 18:00 $\mathrm{h}$, antes do fornecimento das dietas). A partir do primeiro dia de coleta, 24 horas após o fornecimento da refeição, as fezes eram pesadas, e a urina medida após o que eram amostradas (20\% do peso total), individualmente. As amostras foram acondicionadas em sacos plásticos devidamente identificados e foram congeladas imediatamente após a coleta para posterior análise. Ao término de cada período as amostras foram descongeladas para o preparo de amostras compostas destinadas à posterior análise.

As fezes foram coletadas em bolsas de lona, revestidas de plástico, e devidamente ajustadas aos animais por meio de cintas. As gaiolas possuíam piso telado que permitia a coleta da urina. Para evitar a volatilização do nitrogênio da urina, foram adicionados diariamente nas bandejas de coleta $15 \mathrm{ml}$ de ácido clorídrico, diluído em água na proporção de $1: 1$. 


\subsubsection{Análises químicas}

Para se realizar a determinação da digestibilidade aparente das diversas frações e os nutrientes digestiveis totais (NDT), tanto as silagens fornecidas, quanto as fezes coletadas foram analisadas quanto aos teores de:

- Matéria Seca (MS)

- Extrato Etéreo (EE)

- Fibra Bruta (FB)

- Proteína Bruta (PB)

- Fibra Detergente Ácido (FDA)

- Fibra Detergente Neutro (FDN)

- Cinzas.

- Lignina

- Extrativo Não Nitrogenado (ENN) - calculado

- Celulose - calculada

- Hemicelulose - calculada

Ainda nas silagens, também foram determinados os teores de:

- Nitrogênio na FDA

- Nitrogênio na FDN

- Nitrogênio Não Protéico

- Nitrogênio Solúvel

Nas amostras de urina foram determinados os valores de nitrogênio total, para realização do balanço de nitrogênio. 
As determinações de matéria seca, extrato etéreo, fibra bruta, proteína bruta, extrativo não nitrogenado, cinzas e nitrogênio amoniacal foram feitas de acordo com os métodos da A.O.A.C. (1975).

As análises de fibra detergente ácido e fibra detergente neutro, lignina, nitrogênio insolúvel em detergente ácido e em detergente neutro foram feitas pelo método descrito por VAN SOEST et al. (1991).

O nitrogênio solúvel e o nitrogênio não protéico foram determinados segundo o método descrito por KRISHNAMOORTHY et. al. (1982).

Os cálculos de coeficientes de digestibilidade aparente foram feitos através das fórmulas apresentadas por SCHNEIDER e FLATT (1975).

\subsubsection{Análise estatística}

$\mathrm{O}$ experimento foi analisado como um delineamento em quadrado latino incompleto $(6 \times 5)$, conforme o modelo:

\begin{tabular}{|l|c|}
\hline Causa da Variação & Graus de Liberdade \\
\hline - Cameiros & 5 \\
\hline - Tratamentos & 5 \\
\hline - Períodos & 4 \\
\hline - Resíduo & 15 \\
\hline - Total & 29 \\
\hline
\end{tabular}

A análise da variância foi realisada pelo procedimento GLM do Sistema de Análise Estatística (SAS), e as diferenças entre as médias foi feita pelo teste de Duncan.

Para este experimento também foi realizada a análise exploratória em todas as variáveis, através do procedimento LAB do SAS. Concluiu-se que as variáveis matéria seca, proteína bruta, digestibilidade da hemicelulose, e nitrogênio solúvel apresentavam 
problemas de escala. Pela transformação sugerida pelo método Box-Cox, as potências $1,2,-2,2,2$ e $-2,4$ foram utilizadas, respectivamente para a transformação da matéria seca, prot. bruta, digestibilidade da hemicelulose e nitrogênio solúvel, os problemas foram resolvidos. Ainda as variáveis lignina, nitrogênio retido/nitrogênio ingerido e nitrogênio retido/nitrogênio absorvido apresentaram problemas de escala e no caso da última havia ainda um problema de "outliers", que não puderam ser resolvidos uma vez que o SAS não apresentou sugestão de fator de correção, o que foi justificado por alguns valores negativos determinados para estas variáveis. 


\section{RESULTADOS e DISCUSSÃO}

\section{1 - Ensaio de consevação em silos de laboratório}

A Tabela 1 apresenta os dados de teor e recuperação de matéria seca das silagens obtidas nos diversos tratamentos. Em relação à testemunha, a aditivação aumentou significativamente $(\mathrm{P}<0,05)$ a matéria seca das silagens até o tratamento com $10 \%$ de polpa de citros. A silagem aditivada com fubá de milho apresentou a menor recuperação da matéria seca $(P<0,05)$. A maior recuperação de matéria seca ocorreu nos tratamentos com adição de $5 \%$ e $10 \%$ de polpa de citros. Os demais tratamentos situaram-se em posição intermediária.

Tabela 1: Teor e recuperação da matéria seca (\%)

\begin{tabular}{|c|c|c|c|c|c|c|}
\hline \multirow[t]{2}{*}{ Parâmetros $^{1}$} & \multicolumn{6}{|c|}{ Tratamentos $^{2}$} \\
\hline & $\mathbf{T}-\mathbf{0}$ & $T-5$ & $T-10$ & $T-15$ & $\mathbf{T}-\mathbf{M}$ & $\mathrm{C.V}^{3}$ \\
\hline MS (\%) & $19,1^{c}$ & $21,6^{b}$ & $24,2^{\mathrm{a}}$ & $25,8^{a}$ & $24,2^{\mathrm{a}}$ & 17,1 \\
\hline Rec. MS (\%) & $81,3^{b c}$ & $86,4^{\mathrm{ab}}$ & $91,1^{\mathrm{a}}$ & $80,0^{b c}$ & $77,4^{\mathrm{c}}$ & 7,2 \\
\hline
\end{tabular}

Os valores médios encontrados, no geral, estão concordes com os da literatura. Assim, Watson ${ }^{8}$ e Nash (1960), citados por McDONALD (1981), em uma pesquisa de cerca de 800 experimentos realizados entre 1938 e 1960, determinaram perda média de $16,1 \%$ da matéria seca durante a ensilagem, tendo este valor variado em função do tipo de material e do tratamento por ele sofrido antes da ensilagem. Materiais mais úmidos tenderam a apresentar menores teores de recuperação de matéria seca.

\footnotetext{
${ }^{8}$ WATSON, S.J. and NASH, M.J. The conservation of grass and forage crops, Oliver and Boy, Edinburgh 1960.
} 
Era de se esperar que o tratamento com adição de $15 \%$ de polpa de citros fosse superior, uma vez que este tratamento sequer apresentou efluente, como pode ser observado na Tabela 2, além de possuir melhores condições para boa fermentação (maiores níveis de matéria seca e carboidratos não estruturais). Este resultado, de certa forma inesperado, poderia estar relacionado a acidificação mais lenta do meio, em função do elevado poder tamponante da polpa de citros, conforme referência de VAN SOEST (1987), muito embora o poder tampão determinado para as forragens (Tabela 7) não pareça ser fator limitante.

Outra explicação, dentro do contexto do presente trabalho, seria a entrada de ar na massa ensilada, por ocasião da retirada do efluente. ALLRED e KENNEDY (1956) afirmam que, para que os silos de laboratório sejam utilizados com sucesso para estimar o efluente e as perdas por fermentação que ocorrem em silos de grande escala, cuidados devem ser tomados no sentido de se tornar possivel a aplicação de pressão. A pressão em silos de grande escala é um importante fator a influenciar a magnitude de perda de efluente. Ela também influencia a quantidade e movimento de ar e umidade dentro da massa ensilada, que em contrapartida, tem influência marcante sobre o tipo e atividade dos microorganismos.

No presente experimento não foi possível controlar a pressão sobre os silos experimentais. $\mathrm{Na}$ realidade nenhuma pressão constante foi aplicada ao material. Unicamente se vedou a superficie superior do silo com uma tampa de madeira forrada com plástico, que se ajustava ao tubo, e, nos primeiros dias, por ocasião da retirada do efluente, esta tampa era pressionada até que o material se consolidasse, sendo em seguida liberado novamente da pressão. Quando esta pressão era retirada, era possível a observação de uma movimentação da massa, no sentido de se expandir, permitindo assim a entrada de ar. Uma vez que com o aumento do teor de matéria seca do material a compactação fica mais dificil, os tratamentos com $15 \%$ de polpa de citros e eventualmente o com $10 \%$ de fubá de milho podem ter sido os mais prejudicados por esta renovação do ar na massa. Estes fatos, mais do que um elevado poder tampão da polpa 
de citros, podem ter levado à obtenção de dados que não reproduzem a verdadeira situação em silos de grande escala.

Tabela 2: Volume de efluente dos silos experimentais

\begin{tabular}{cccccc}
\hline Volume & \multicolumn{5}{c}{ Tratamentos } \\
\cline { 2 - 6 } & T - 0 & T - 5 & T - 10 & T - 15 & T - M* \\
\hline $\mathrm{ml}$ & 67,6 & 4,4 & 3,4 & -- & - \\
$\mathrm{ml} / \mathrm{kg}^{*}$ & 40,4 & 2,5 & 2,0 & - & - \\
\hline
\end{tabular}

*Volume de efluente em $\mathrm{ml}$ por $\mathrm{kg}$ de material ensilado

Esta deficiência de equipamentos que permitissem um total controle das condições de ensilagem não impediu, todavia, que se observasse que todos os tratamentos permitiram boa conservação da massa ensilada, pois a avaliação química das silagens produzidas demonstra que, descartando-se o material deteriorado pela vedação deficiente, a conservação foi muito boa. SILVEIRA (1975), cita os critérios para avaliação de silagem como sendo: $\mathrm{pH}$ inferior a 4,2 ; ácido butírico menor que $0,2 \%$ na matéria seca e nitrogênio amoniacal igual ou inferior a 11 e $12 \%$ do nitrogênio total para silagens de boa qualidade. Os valores aqui apresentados (Tabela 3) enquadram-se perfeitamente nesta classificação e não houve diferença estatística significativa entre os tratamentos $(\mathrm{P}>0,05)$. Os dados são discordantes daqueles obtidos por BOIN (1975), principalmente no que se refere à silagem testemunha, que naquele caso apresentou características de má conservação. Um fator que deve ter influenciado esta diferença é que o autor não permitiu a drenagem do efluente durante o processo fermentativo, o que ocorreu neste caso. Isto certamente contribuiu para o menor teor de matéria seca da silagem obtida pelo autor ( $12,3 \%$ de MS contra $18,9 \%$ no presente experimento). CORSI et al. (1971), também não conseguiram ótimo abaixamento do $\mathrm{pH}$ trabalhando com a ensilagem do capim napier (19,2\% de matéria seca), sob diversos tratamentos ( $20 \%$ de fubá de milho; $15 \%$ de feno de Rhodes; $15 \%$ de palha de arroz; $15 \%$ de soja perene; condicionamento e emurchecimento; emurchecimento no campo por 7-8 horas). Todos 
os tratamentos apresentaram pH acima de 4,2, muito embora não tenha sido detectado ácido butírico, com exceção do tratamento testemunha $(0,11 \%$ na MS).

Tabela 3: Parâmetros de conservação das silagens

\begin{tabular}{lcccccc}
\hline \multicolumn{1}{c}{ Parâmetros $^{1}$} & \multicolumn{7}{c}{ Tratamentos $^{2}$} \\
\cline { 2 - 7 } & T - 0 & T -5 & T - 10 & T - 15 & T - M & C.V. $^{3}$ \\
\hline pH & 3,84 & 3,82 & 3,76 & 3,86 & 3,78 & 2,0 \\
N-NH $_{3}$ (\% do N-total) & $12,7^{\mathrm{a}}$ & $11,8^{\mathrm{ab}}$ & $11,5^{\text {ab }}$ & $10,9^{\mathrm{b}}$ & $12,5^{\mathrm{a}}$ & 8,5 \\
Ác. Acético $^{4}$ & 1,58 & 1,37 & 1,67 & 1,35 & 1,76 & 24,1 \\
Ác. Propiônico $^{4}$ & 0,019 & 0,016 & 0,024 & 0,022 & 0,019 & 6,1 \\
Ác. Butírico $^{4}$ & 0,053 & 0,22 & 0,047 & 0,058 & 0,147 & 24,0 \\
\hline
\end{tabular}

${ }^{1} \mathrm{~N}-\mathrm{NH}_{3}=$ nitrogênio amoniacal

${ }^{2}$ Médias na mesma linha assinaladas por letras distintas diferiram entre si - Duncan (P<0.05).

${ }^{3}$ Coeficiente de variação.

${ }^{4}$ Porcentagem da matéria seca.

de FARIA et al. (1972), avaliando o efeito da utilização da polpa de laranja seca como aditivo na ensilagem do capim napier, utilizou valores de $0,5,10,15$ e $20 \%$ da matéria original. Os valores de $\mathrm{pH}$ relatados foram superiores aos aqui determinados (respectivamente 4,39, 4,46, 4,20, 4,08 e 4,07). Os teores de ácido acético foram um pouco inferiores e os de ácido butírico se assemelharam muito aos apresentados na Tabela 3, respectivamente 1,2 e 0,$11 ; 1,00$ e 0,$0 ; 0,89$ e 0,$05 ; 0,75$ e 0,$01 ; 0,54$ e $0,0 \%$ de ácido acético e butírico na MS, para os tratamentos testemunha, com 5, 10, 15 e $20 \%$ de polpa de laranja.

A Tabela 4 apresenta os valores de carboidratos solúveis do material antes da ensilagem ( $\%$ na matéria seca). Estes valores foram obtidos através de análises em duplicata de uma única amostra de cada mistura realizada. Por este motivo não foram submetidos à análise estatística, da mesma forma que os valores de poder tampão apresentados na mesma tabela. $\mathrm{O}$ teor de carboidratos solúveis foi um pouco abaixo daquele já reportado anteriormente por diversos autores. GUTIERREZ e de FARIA 
(1979), trabalhando com quatro variedades de capim napier em três estágios de crescimento encontraram valores variando de 9,58 a $13,92 \%$ de carboidratos solúveis na matéria seca. Estes autores utilizaram a metodologia de extração dos carboidratos com etanol $80 \%$ a quente, que segundo os próprios autores apresenta melhores resultados na extração, distinta da que foi aplicada neste trabalho onde a extração foi realizada simplesmente pela agitação da amostra por 30 minutos em água destilada.

Este parâmetro também foi avaliado por de FARIA et al. (1972) em seu experimento sobre a aditivação do capim napier com polpa de laranja fresca ou seca aos níveis de 5, 10, 15 e $20 \%$. Neste experimento o método de determinação dos carboidratos solúveis foi o de BALWANI (1965) o mesmo aqui utilizado, neste caso descrito por JOHNSON et al. (1967). Mesmo assim, os resultados diferem para a testemunha e as forragens tratadas, havendo concordância unicamente no caso da polpa de citros. Os valores obtidos pelos autores foram 10,52;15,91; 19,07; 21,10;24,05 e $26 \%$ respectivamente para a testemunha, para os tratamentos com $5,10,15,20 \%$ de polpa de laranja seca e para a polpa propriamente dita. Como pode ser observado na Tabela 4, estes valores são superiores em quase todos os casos, com exceção da polpa de citros. No presente trabalho estranhamente não houve incremento marcante no teor de carboidratos solúveis com o aumento no teor dos aditivos.

Tabela 4: Carboidratos solúveis e poder tampão do material antes da ensilagem

\begin{tabular}{lccccccc}
\hline \multicolumn{1}{c}{ Parâmetros } & \multicolumn{7}{c}{ Tratamentos } \\
\cline { 2 - 8 } & T - 0 & T - 5 & T - 10 & T - 15 & T - M & Polpa & Milho \\
\hline Carboidratos solúveis $^{1}$ & 7,6 & 10,6 & 11,6 & 12,2 & 5,6 & 25,2 & 2,2 \\
Poder Tampão $^{2}$ & 2,25 & 2,95 & 2,95 & 2,87 & 1,82 & $\ldots$ & - \\
\hline
\end{tabular}

\% na matéria seca.

${ }^{2} \mathrm{~g}$ de ácido lático/100 $\mathrm{g}$ de M.S. da amostra (análise feita no material seco em estufa)

Com relação ao poder tampão, GUTIERREZ (1975), observou que a maturidade foi responsável pelo decréscimo nos ácidos orgânicos do capim napier, e seu poder 
tampão caiu de 38 a 40 e.mg de $\mathrm{HCl} / 100 \mathrm{~g}$ de $\mathrm{MS}$ aos 37 dias de desenvolvimento para 13 a 17 e.mg aos 67 dias de desenvolvimento. Também TOSI (1973) avaliando seis gramíneas forrageiras tropicais, cortadas no mesmo estádio de desenvolvimento, verificou que o capim elefante, cv. Taiwan A-148 apresentou o menor poder tampão ao ácido clorídrico: respectivamente 24,$59 ; 18,36 ; 16,68 ; 22,63 ; \underline{13,31}$ e 16,83 e.mg. de $\mathrm{HCl} / 100$ g de matéria seca, para a B. decumbens, P. maximum, A.gayanus, H.rufa, P.purpureum,

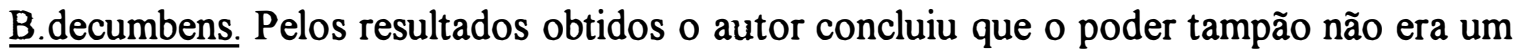
fator limitante à ensilagem do capim napier.

Os valores são aqui apresentados na forma de gramas de ácido lático por $100 \mathrm{~g}$ de MS, uma vez que este foi o ácido utilizado na metodologia utilizada, proposta por McDONALD e HENDERSON (1962). Estes valores permitem comparação com os dados apresentados por estes autores e em muito se assemelham a eles, quando comparados com outras gramíneas de clima temperado, realmente não parecendo ser fator limitante. 


\section{2 - Ensaio de digestibilidade}

A Tabela 5 mostra o teor de matéria seca das silagens utilizadas no ensaio de digestibilidade, em conjunto com seus respectivos consumos durante os períodos de coleta ( $90 \%$ do consumo voluntário). O teor de matéria seca cresceu significativamente com a aditivação tanto da polpa quanto do fubá. Os valores observados são muito próximos aos esperados, de acordo com os cálculos feitos na apresentação do material e métodos. Como já havia sido constatado por EVANGELISTA et al. (1987) e MELOTTI (1983), que trabalharam com silagens de capim napier aditivados com diferentes níveis de rolão de milho, os maiores valores foram encontrados nas silagens com maior proporção de aditivos. A silagem de milho pode ser considerada como sendo de baixo teor de matéria seca.

Tabela 5: Teor e consumo de matéria seca, digestibilidade da matéria seca, digestibilidade da matéria orgânica e NDT

\begin{tabular}{lcccccccc}
\hline Parâmetros $^{1}$ & \multicolumn{7}{c}{ Tratamentos $^{2}$} \\
\cline { 3 - 8 } & & T - & T - 5 & T -10 & T - 15 & T - M & T - S & CV $^{3}(\%)$ \\
\hline MS & $(\%)$ & $18,9^{\mathrm{d}}$ & $21,4^{\mathrm{c}}$ & $25,8^{\mathrm{b}}$ & $27,7^{\mathrm{a}}$ & $26,1^{\mathrm{b}}$ & $25,1^{\mathrm{b}}$ & 3,5 \\
CMS $^{4}$ & & $35,8^{\mathrm{d}}$ & $39,9^{\mathrm{cd}}$ & $46,5^{\mathrm{b}}$ & $49,7^{\mathrm{ab}}$ & $50,9^{\mathrm{a}}$ & $41,9^{\mathrm{c}}$ & 6,9 \\
DMS & $(\%)$ & $53,8^{\mathrm{c}}$ & $56,1^{\mathrm{de}}$ & $60,7^{\mathrm{bc}}$ & $62,4^{\mathrm{ab}}$ & $64,9^{\mathrm{a}}$ & $58,9^{\mathrm{cd}}$ & 3,7 \\
DMO & $(\%)$ & $54,2^{\mathrm{c}}$ & $57,0^{\mathrm{c}}$ & $61,7^{\mathrm{b}}$ & $63,4^{\mathrm{ab}}$ & $65,7^{\mathrm{a}}$ & $60,3^{\mathrm{b}}$ & 3,7 \\
NDT & $(\%)$ & $52,9^{\mathrm{c}}$ & $55,2^{\mathrm{c}}$ & $59,5^{\mathrm{b}}$ & $60,9^{\mathrm{b}}$ & $65,7^{\mathrm{a}}$ & $59,2^{\mathrm{b}}$ & 3,9 \\
\hline
\end{tabular}

1 MS = matéria seca; CMS = consumo de matéria seca; DMS = Digestibilidade aparente da matéria seca; DMO = digestibilidade aparente da matéria orgânica; NDT = nutrientes digestíveis totais. ${ }^{2}$ Médias na mesma linha assinaladas por letras distintas diferiram entre si - Duncan (P<0.05). ${ }^{3}$ Coeficiente de variação.

${ }^{4} \mathrm{Em}$ gramas por $\mathrm{kg}$ de peso metabólico (90\% do consumo voluntário).

A silagem de capim napier com $10 \%$ de polpa de citros peletizada (PCP), apresentou nível de matéria seca semelhante à silagem de milho, porém, determinou 
consumo voluntário superior. WING (1982) menciona que em diversos experimentos onde subprodutos da indústria citrícola foram utilizados como aditivos na ensilagem de forragens, estes produtos contribuíram para melhor aceitação do produto final pelos animais e aumentaram a eficiência de preservação, porém o presente trabalho revela que esta não seria somente uma propriedade da polpa de citros, mas muito provavelmente estaria relacionada à melhor conservação da massa ensilada, uma vez que o tratamento com fubá apresentou o maior consumo, juntamente com o de $15 \%$ de PCP.

Ainda com relação ao consumo de matéria seca, o baixo teor de proteína bruta determinado em praticamente todos os tratamentos (Tabela 6) certamente influiu negativamente sobre este parâmetro. A deficiência protéica limita a fermentação ruminal, e consequentemente a taxa de passagem dos alimentos pelo trato digestivo, o que determina um menor consumo. Isto já foi demostrado por Demarquilly et al. ${ }^{9}$, citados por McDONALD (1981), que observaram um aumento de $48 \%$ na ingestão de matéria seca quando o teor de nitrogênio total era de $8,6 \%$ e foi suplementado, enquanto que houve um aumento de somente $9 \%$ quando o teor de nitrogênio total da silagem era de $13,9 \%$.

De qualquer forma, é interessante notar que mesmo entre as silagens tratadas com polpa de citros, que não apresentaram diferença significativa nos teores de proteína, houve diferenciação dos níveis de consumo, neste caso, possivelmente ocasionados por outros fatores como a palatabilidade, teor de matéria seca e de carboidratos solúveis das silagens. Por sua vez, quando comparamos as silagens tratadas com polpa de citros e a silagem de milho, é possível observar que mesmo tendo a última apresentado teor significativamente superior de proteína bruta $(P<0,05)$, diga-se de passagem bastante próximo à recomendação para ovinos em manutenção, seu consumo foi significativamente inferior às silagens com 10 e 15\% de polpa de citros, o que também conduz a possíveis diferenças de palatabilidade, teor de matéria seca e eventualmente limitação da fermentação ruminal, neste caso mais provavelmente associada à deficiência de carboidratos não estruturais na silagem de milho.

\footnotetext{
${ }^{9}$ DEMARQUILLY, C.; HAUREZ, Ph.; JOURNET, M.; LELONG, C. e MALTERRE, C. Bull. technique dinformation, 264-265, 1001-1008. 1971.
} 
Outro ponto que chama atenção em relação à matéria seca da silagens é o fato de que o incremento na matéria seca foi maior do tratamento com $5 \%$ de polpa para o de $10 \%$ do que deste para o de $15 \%$. Ainda de acordo com WING (1982), a absorção de efluentes pela polpa de citros como aditivo à ensilagem aumentou em cada incremento da mesma até $113 \mathrm{~kg}$ por tonelada. Todavia, a melhora na absorção diminuiu rapidamente a partir dos $68 \mathrm{~kg}$ e portanto este pareceu ser o nível mais adequado. Estes dados parecem concordar com o que foi observado nestes experimentos pois o nível de $10 \%$ de polpa parece ter sido suficiente para boa preservação da silagem, conforme já discutido anteriormente, e também não houve diferença em termos de digestibilidade entre os tratamentos com $10 \%$ e $15 \%$ de $\mathrm{PCP}(\mathrm{P}>0,05)$.

de FARIA et al. (1972), testando também o efeito da utilização da polpa de laranja seca como aditivo na ensilagem do capim napier, adicionou valores de 5, 10, 15 e $20 \%$ em relação à matéria original. Neste experimento o teor de matéria seca do capim foi de $20,1 \%$ e de $23,9,26,9,32,1$ e $35,3 \%$ para os demais tratamentos em ordem crescente. Estes valores muito se assemelham aos aqui obtidos, se considerarmos que partiu-se de um valor, na testemunha, com mais de um ponto percentual acima de matéria seca.

A Tabela 5 traz também os valores de digestibilidade aparente da matéria seca, matéria orgânica e nutrientes digestiveis totais para os diferentes tratamentos.

Aqui novamente os valores seguem um padrão crescente, conforme aumenta a aditivação. Destaca-se o efeito do fubá de milho, que foi semelhante ao tratamento com $15 \%$ de polpa de citros nos parâmetros de digestibilidade de matéria orgânica e matéria original, e ainda superou este mesmo tratamento no que se refere aos nutrientes digestiveis totais, mesmo tendo apresentado um teor de matéria seca inferior. Novamente destaca-se que a silagem com $15 \%$ de polpa de citros não apresentou incrementos significativos para os valores analisados em comparação à silagem com $10 \%$ de polpa de citros. A silagem de milho foi inferior ao tratamento com $10 \%$ de PCP no que se refere ao consumo de matéria, mas apresentou valores semelhantes em termos de parâmetros de digestibilidade. 
O teor superior de matéria mineral determinado para as silagens tratadas com polpa de citros (Tabela 10), parece não ter influenciado a digestibilidade da matéria orgânica das mesmas em relação ao tratamento com fubá ou mesmo à silagem de milho propriamente dita.

Em relação aos nutrientes digestíveis totais (NDT), pode-se dizer que os valores obtidos estão concordantes com aqueles encontrados na literatura. TOSI (1972), trabalhando com silagens de capim napier colhido aos 80 dias de crescimento, no pico de verão, aditivadas com níveis crescentes de melaço obteve valores médios de NDT de 57,$2 ; 54,3 ; 58,7 ; 56,3 ; 54,3$ e 59,7 respectivamente para as silagens testemunha, e com a adição de 1,5; 3,0; 4,5, 6,0 e 7,5\% de melaço. Estes valores de NDT são muito próximos aos aqui obtidos, embora no presente trabalho a aditivação tenha sido feita através da PCP. Aparentemente estes valores estão dentro de uma faixa de variação razoável para o capim napier, pois também MELOTTI et al. (1968), utilizando um capim napier colhido em final de março, como no presente trabalho, porém com 190 dias de crescimento, ao qual foram adicionados $1,7 \%$ de melaço, obteve um valor calculado de nutrientes digestíveis totais médio de 54,59\% na matéria seca. Ainda MELOTTI et al. (1971), em outro estudo onde utilizou o capim napier cortado aos 78 dias de crescimento vegetativo, adicionado de $3,4 \%$ de melaço mais água, diluido na proporção de $1: 1$, obteve um valor de NDT de 60,4\% na matéria seca, valor este muito próximo daqueles aqui obtidos para as silagens aditivadas com 10 e $15 \%$ de polpa de citros. Da mesma forma, BOIN et al. (1968), avaliando a digestibilidade de silagens de capim napier, sorgo e milho, obteve valores de nutrientes digestíveis totais respectivamente de 55,7;60,2 e 63,0\% na matéria seca; neste trabalho o capim napier foi cortado com 144 a 157 dias de crescimento a partir do plantio, e a ele também foi adicionado 1,7\% de melaço diluído em água na proporção $1: 1$.

Em todos os trabalhos citados os valores de NDT são muito próximos, com exceção do trabalho conduzido por MELOTTI et al., em 1971, que apresentou valores ligeiramente superiores. Isto talvez represente um patamar de digestibilidade para este tipo de material, pois independente da aditivação, e até dos diferentes estágios de 
desenvolvimento, o teor de NDT é bastante constante. Também há que se considerar que todos os trabalhos citados, incluindo o presente trabalho, foram realizados com forragem em estádio de crescimento mais avançado do que seria a recomendação para o corte do capim napier (60 dias). Isto pode ter influenciado os resultados obtidos.

A Tabela 6 apresenta os dados relativos à fração nitrogenada das silagens analisadas. Uma vez que o capim já se encontrava com idade ligeiramente avançada (72 dias, quando se pretendia realizar a ensilagem aos 60 dias), e sendo a polpa de citros um alimento basicamente energético, normalmente com teor de proteína em torno de $6 \%$ (NRC, 1989), as silagens aditivadas com PCP, apresentaram menor teor de proteína bruta que o tratamento com fubá de milho e que a silagem de milho. Os valores encontrados se assemelham muito aos dados de silagem de capim napier encontrados na literatura para forragens em semelhante estágio de desenvolvimento.

Como termo de comparação podemos citar BOIN (1975), que determinou valores de 6,04 e $6,09 \%$ de proteína bruta em silagens de capim elefante com 63 dias de crescimento, aditivados respectivamente com melaço e ácido fórmico. Da mesma forma, YEO (1977), analisando o efeito da maturidade do capim elefante sobre seu valor nutritivo encontrou um teor de $5,88 \%$ de proteína bruta para um capim cortado aos 70 dias de crescimento. Já LAVEZZO et al. (1993), utilizando um capim elefante CV. Roxo, aos 70 dias de crescimento encontrou valores de 10,88\% de proteína bruta.

No que se refere à digestibilidade da proteína, esta também foi significativamente menor para a testemunha e nos tratamentos com a utilização da polpa de citros aos níveis de 5 e 10\%, em relação aos demais tratamentos. Isto certamente está relacionado ao menor teor de proteína destes tratamentos e à menor disponibilidade da proteína da PCP.

O teor de proteína das silagens não foi corrigido, e com isto ficou abaixo do teor mínimo preconizado para ovinos em manutenção, que seria de cerca de 9,5\% na matéria seca, segundo o NRC (1985). Com isto, certamente houve limitação da fermentação ruminal, interferindo na digestibilidade de todas as demais frações, limitando o consumo e prejudicando o resultado de digestibilidade da própria proteína, uma vez que a 
contribuição do nitrogênio de origem metabólica nas fezes faz com que os resultados de digestibilidade aparente sejam inferiores.

Tabela 6: Teor de proteína bruta e suas frações e digestibilidade da proteína bruta.

\begin{tabular}{|c|c|c|c|c|c|c|c|}
\hline \multirow[t]{2}{*}{ Parâmetros ${ }^{1}$} & \multicolumn{7}{|c|}{ Tratamentos $^{2}$} \\
\hline & $\mathrm{T}-0$ & $T-5$ & $T-10$ & $T-15$ & $\mathrm{~T}-\mathrm{M}$ & $\mathrm{T}-\mathrm{S}$ & $\mathrm{CV}(\%)$ \\
\hline$(\% \mathrm{MS})$ & $6,2^{c}$ & $6,4^{b c}$ & $6,5^{b c}$ & $6,8^{b}$ & $7,6^{\mathrm{a}}$ & $8,3^{\mathrm{a}}$ & 11,8 \\
\hline DPB & $44,6^{b}$ & $44,4^{b}$ & $45,2^{b}$ & $51,9^{\mathrm{a}}$ & $55,5^{\mathrm{a}}$ & $52,3^{\mathrm{a}}$ & 8,4 \\
\hline N-FDA (\%-Ntotal) & $12,9^{b c}$ & $14,4^{\mathrm{ab}}$ & $16,9^{a}$ & $14,8^{\mathrm{ab}}$ & $7,9^{d}$ & $11,2^{\mathrm{c}}$ & 12,7 \\
\hline N-FDN (\%N-total) & $15,9^{c}$ & $19,2^{b}$ & $22,3^{a}$ & $22,6^{\mathrm{a}}$ & $12,1^{d}$ & $14,5^{\text {cd }}$ & 11,8 \\
\hline (\%N-total) & $54,7^{\mathrm{c}}$ & $56,1^{b c}$ & $56,6^{b c}$ & $58,3^{b}$ & $62,6^{\mathrm{a}}$ & $65,6^{\mathrm{a}}$ & 8,8 \\
\hline$(\% \mathrm{~N}$-total $)$ & $46,3^{a}$ & $45,0^{\mathrm{a}}$ & $44,3^{a}$ & $42,6^{\mathrm{a}}$ & $38,3^{b}$ & $35,1^{b}$ & 6,1 \\
\hline$(\% \mathrm{~N}-\mathrm{Sol})$ & $84,4^{a}$ & $80,4^{\mathrm{ab}}$ & $78,5^{a b}$ & $73,1^{b}$ & $61,6^{c}$ & $53,7^{c}$ & 9,4 \\
\hline
\end{tabular}

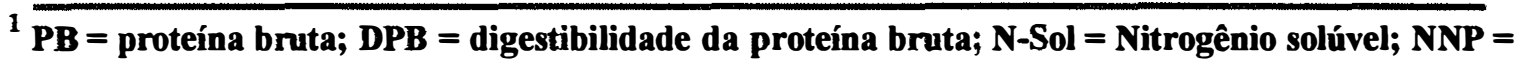
nitrogênio não protéico; $\mathbf{N}$-FDA = nitrogênio insolúvel em fibra detergente ácido; $\mathbf{N}$-FDN = nitrogênio insolúvel em fibra detergente neutro;

${ }^{2}$ Médias na mesma linha assinaladas por letras distintas diferiram entre si - Duncan $(\mathrm{P}<0.05)$.

${ }^{3}$ Coeficiente de variação.

Segundo VAN SOEST (1994), o fornecimento de níveis baixos de nitrogênio não limita a fermentação ruminal, desde que a reciclagem da uréia através da saliva possa satisfazer os requerimentos do animal. Existe porém um nível (aproximadamente entre 6 e $8 \%$ de proteína bruta), abaixo do qual a reciclagem não satisfaz os requerimentos e a ingestão ou a digestibilidade caem. Com exceção da silagem de milho, todos os demais tratamentos apresentaram teores de proteína bruta dentro desta faixa crítica.

Além disso, a proteína metabólica fecal é relativamente constante e, portanto, baixas ingestões de proteína podem levar a resultados de digestibilidade que não representam a realidade, uma vez que mesmo a proteína apresentando alta digestibilidade, aparentemente esta seria baixa, devido à excreção dos resíduos metabólicos. O problema, 
nesta situação, seria portanto de pouca quantidade de proteína, e não baixa digestibilidade.

Somado a isto, uma porção considerável da proteína da PCP normalmente está associada à fibra ou torna-se indisponível ao animal devido à reação de Maillard (WALDO e GOERNG, 1979), ocasionada possivelmente pelo processo de aquecimento a que é submetida durante sua secagem. Isto pode ser observado indiretamente nos valores significativamente maiores de nitrogênio insolúvel em FDN e FDA apresentados pelas silagens aditivadas com PCP. KRISHNAMOORTHY et al. (1982), também afirmam que os suplementos protéicos contém uma pequena quantidade de proteína de degradação lenta, porém, as forragens, os grãos fermentados e subprodutos, como é o caso da PCP, contém porções significativas desta fração do nitrogênio. $\mathrm{O}$ nitrogênio insolúvel em fibra detergente ácido é considerado indisponível para o animal, enquanto o insolúvel em fibra detergente neutro, mas solúvel em fibra detergente ácido, tem degradação lenta.

BOIN (1975), trabalhando com silagens de capim napier (63 dias de desenvolvimento) tratadas com ácido fórmico obteve valores de digestibilidade de proteína muito semelhantes $(42,46 \%)$ aos aqui apresentados para as silagens testemunha e aquelas aditivadas com 5 e 10\% de PCP. O autor, em seu trabalho, menciona que o tratamento com ácido fórmico possivelmente foi a causa da menor digestibilidade da proteína, pois este aditivo tem o efeito de proteger a proteína da ação das bactérias no rúmen, tornando-a menos disponível, como ocorre no caso em questão, devido ao aquecimento da polpa de citros.

Os valores de nitrogênio solúvel e nitrogênio não protéico foram avaliados no intuito de se gerar informação para utilização deste tipo de silagem no sistema de balanceamento de dietas da Universidade de Cornell, o "Cornell Net Carbohidrate and Protein Sistem". Pichard ${ }^{10}$ e Van Soest, citados por SNIFFEN et al. (1992), afirmam que essencialmente toda a proteína solúvel em silagens e forragens frescas está na forma de

\footnotetext{
${ }^{10}$ PICHARD, D.G. and VAN SOEST, P.J. Protein solubility of ruminant feeds. Proc. Cornell Nutr. Conf., Ithaca, N.Y. p. 91. 1977.
} 
nitrogênio não protéico. Os valores aqui determinados variaram entre 53 e $84 \%$ do nitrogênio solúvel na forma de nitrogênio não protéico. Isto provavelmente é conseqüência do fato de que tanto o nitrogênio total quanto o nitrogênio solúvel e o não protéico foram analisados em amostras secas em estufa. Uma vez que esta fração não protéica é composta basicamente de amônia, peptídeos e amino ácidos, parte pode ter sido perdida por volatilização durante o processo de secagem, o que gerou os valores inferiores aos esperados.

O balanço de nitrogênio é apresentado na Tabela 7. Ele foi negativo para a silagem feita exclusivamente de capim, que se assemelhou estatisticamente à silagem com $5 \%$ de PCP, que apresentou um balanço positivo porém muito próximo a zero, sendo que elas diferiram das demais. É importante observar, no entanto, que os resultados apresentaram alto coeficiente de variação, o que dá uma característica especulativa a qualquer inferência realizada sobre os resultados. De qualquer forma, os resultados são comparáveis àqueles encontrados na literatura.

Tabela 7: Balanço de nitrogênio

\begin{tabular}{lccccccc} 
Parâmetros $^{1}$ & \multicolumn{7}{c}{ Tratamentos $^{2}$} \\
\cline { 2 - 7 } & T - 0 & T - 5 & T - 10 & T - 15 & T - M & T - S & CV (\%) \\
\hline N-ret/N-ing & $-6,2^{\mathrm{b}}$ & $4,9^{\mathrm{b}}$ & $17,5^{\mathrm{a}}$ & $24,2^{\mathrm{a}}$ & $27,1^{\mathrm{a}}$ & $21,3^{\mathrm{a}}$ & 58,4 \\
N-ret/N-abs & $-18,9^{\mathrm{c}}$ & $9,9^{\mathrm{b}}$ & $39,0^{\mathrm{a}}$ & $45,1^{\mathrm{a}}$ & $48,0^{\mathrm{a}}$ & $39,9^{\mathrm{a}}$ & 73,4 \\
\hline
\end{tabular}

1 N-ret/N-ing = nitrogênio retido/ nitrogênio ingerido; $\mathrm{N}$-ret/N-abs $=$ nitrogênio retido/ nitrogênio absorvido (cálculo feito com valores em $\mathrm{g} / \mathrm{kg}$ de $\mathrm{PV}^{0,75}$ ).

${ }^{2}$ Médias na mesma linha assinaladas por letras distintas diferiram entre si - Duncan $(P<0.05)$.

${ }^{3}$ Coeficiente de variação.

BOIN (1975) trabalhando com silagens de capim napier (56 dias de crescimento) tratadas com formaldeído ou melaço, utilizando bois zebu, determinou balanço negativo $(-0,037 \% \mathrm{~N}$-retido/N-ingerido e $-0,148 \% \mathrm{~N}$-ret/N-absorvido) para a silagem tratada com formaldeído e muito próximo a zero $(0,069 \mathrm{~N}$-ret/ $\mathrm{N}$-ing e $0,167 \mathrm{~N}$-ret/ $\mathrm{N}$-abs $)$ para a 
silagem tratada com melaço, quando estas foram fornecidas como único alimento. Quando os animais receberam além das respectivas silagens um suplemento na forma de concentrado, estes valores tornaram-se positivos $(21,64$ e $21,23 \% \mathrm{~N}$-ret/N-ing e 36,90 e $36,2 \% \mathrm{~N}$-ret/N-abs respectivamente para as silagens tratadas com formaldeído e melaço). Os valores se comparam aos obtidos no presente trabalho, tanto no que se refere à silagem sem aditivos quanto àquelas aditivadas com PCP (efeito comparável ao fornecimento de concentrados). WALDO et al. (1968) também apresentou dados de baixa retenção de nitrogênio em animais alimentados exclusivamente com silagens de alto teor de umidade. Ainda BOIN (1975), citando Durand ${ }^{11}$ et al., comenta que estes autores observaram que animais alimentados com silagem de alfafa em alguns casos tinham balanço negativo de nitrogênio muito embora aparentemente quantidade suficiente de nitrogênio estivesse sendo ingerida. $O$ autor segue sua explanação dizendo que a razão para este baixo aproveitamento do nitrogênio tem sido atribuída ao teor normalmente baixo de carboidrato prontamente disponível, em silagens de gramíneas e/ou leguminosas, para que as bactérias do rúmen possam maximizar a utilização da grande quantidade de nitrogênio não protéico regularmente presente em silagens de alta umidade. Além deste ponto também devemos considerar que o consumo de matéria seca, e consequentemente de nitrogênio foi diretamente proporcional à quantidade de aditivo, e que as silagens apresentaram baixo teor de proteína.

Esta explicação é bastante coerente para a presente situação pois conforme foi demonstrado, as silagens apresentaram baixo teor de proteína bruta, porém com alto teor de proteína solúvel, estando a maior parte desta na forma de nitrogênio não protéico. $\mathrm{A}$ adição da PCP ou fubá de milho estariam então fornecendo os carboidratos necessários para um melhor aproveitamento do nitrogênio, mesmo estando este em quantidade limitada, conforme já discutido, o que causaria então o melhor aproveitamento da fração nitrogenada, nos tratamentos com maior nível de aditivação. Segundo estudos de

\footnotetext{
$"$ DURAND, M.; ZELTER, S.Z. and TISSERAND, J.L. Influence de qualques technniques de conservation sur l'efficacite de l'azote de la luzerne chez le mouton. Ann. Biol Anim. Bioch. Biophys 8:45-67. 1968.
} 
SCHAILBLY e WING (1974) e WING (1975), a polpa de citros é altamente fermentecível, e sua digestão a nível de rúmen produz ácido acético em níveis elevados, de forma contínua por longos períodos. WING (1982), afirma que parece possível que este padrão particular de fermentação da polpa de citros no rúmen possa conduzir ao uso mais eficiente da amônia, e portanto do nitrogênio não protéico.

A Tabela 8 apresenta os valores médios das diversas frações fibrosas e de carboidratos não estruturais das silagens avaliadas, bem como sua respectiva digestibilidade aparente. Como pode ser observado, exceção feita ao teor de carboidratos não estruturais, entre os tratamentos que utilizaram polpa de citros, os teores de todas as frações diminuem com o aumento do teor de PCP na silagem. Isto se deve ao fato de que, muito embora a polpa de citros seja um subproduto fibroso, seu teor de fibra é bastante inferior àquele encontrado na forragem. Ocorreu portanto uma "diluição" da fibra do capim.

A silagem aditivada com fubá de milho apresentou os valores mais baixos de fibra, sendo isto conseqüência natural da utilização do fubá, que por sua característica de concentrado energético possui valores muito baixos de fibra. Já a silagem de milho não apresentou tendência regular nos resultados, uma vez que para algumas frações igualouse ou até superou os tratamentos com maiores níveis de aditivos, enquanto que em outras assemelhou-se ao tratamento com 5\% de PCP. Isto provavelmente pode ser explicado pelo fato de possuir uma razoável proporção de grãos por ocasião da colheita, muito embora a porção volumosa que constitui a silagem de milho já se encontre em estádio de desenvolvimento bastante adiantado (normalmente mais de 100 dias), e portanto já bastante fibrosa. 
Tabela 8: Composiç̃o bromatológica e digestibilidade da fraç̃o fibrosa.

\begin{tabular}{|c|c|c|c|c|c|c|c|}
\hline \multirow[t]{2}{*}{ Parâmetros $^{1}$} & \multicolumn{7}{|c|}{ Tratamentos ${ }^{2}$} \\
\hline & $T-0$ & $\mathrm{~T}-5$ & $T-10$ & $T-15$ & $\mathrm{~T}-\mathrm{M}$ & $T-S$ & $\mathrm{CV}(\%)$ \\
\hline$(\% \mathrm{MS})$ & $35,1^{\mathrm{a}}$ & $30,9^{b}$ & $26,5^{\mathrm{c}}$ & $24,9^{d}$ & $22,7^{\mathrm{e}}$ & $26,2^{\text {cd }}$ & 3,7 \\
\hline DFB $\quad(\%)$ & 57,0 & 55,2 & 55,3 & 54,7 & 53,8 & 55,3 & 5,1 \\
\hline FDN $\quad(\% M S)$ & $63,6^{a}$ & $56,5^{b}$ & $49,6^{\mathrm{c}}$ & $46,9^{d}$ & $44,6^{\mathrm{e}}$ & $50,5^{\mathrm{c}}$ & 2,5 \\
\hline FDN* (\%MS) & $63,9^{a}$ & $56,9^{b}$ & $50,2^{\mathrm{c}}$ & $47,7^{\mathrm{d}}$ & $44,6^{\mathrm{e}}$ & $50,7^{c}$ & 2,5 \\
\hline DFDN (\%) & 52,4 & 50,9 & 52,3 & 53,1 & 51,6 & 49,7 & 4,9 \\
\hline DFDN* (\%) & $52,7^{a b}$ & $51,3^{\mathrm{ab}}$ & $52,,^{a b}$ & $53,9^{a}$ & $51,5^{\mathrm{ab}}$ & $50,0^{b}$ & 4,9 \\
\hline FDA $\quad(\% \mathrm{MS})$ & $41,0^{a}$ & $39,9^{b}$ & $35,6^{b c}$ & $36,4^{\mathrm{c}}$ & $27,1^{\mathrm{e}}$ & $32,9^{d}$ & 2,9 \\
\hline FDA* $^{*}(\% \mathrm{MS})$ & $41,1^{\mathrm{a}}$ & $37,5^{\mathrm{b}}$ & $33,7^{\mathrm{c}}$ & $32,9^{\text {cd }}$ & $28,2^{\mathrm{e}}$ & $32,1^{d}$ & 3,0 \\
\hline DFDA (\%) & $53,1^{b c}$ & $54,7^{b}$ & $59,0^{\mathrm{a}}$ & $60,7^{\mathrm{a}}$ & $50,3^{\text {cd }}$ & $47,5^{d}$ & 4,5 \\
\hline DFDA* $^{*}(\%)$ & $53,2^{b}$ & $52,9^{\mathrm{b}}$ & $54,5^{\mathrm{ab}}$ & $56,6^{\mathrm{a}}$ & $54,5^{\mathrm{b}}$ & $46,7^{\mathrm{c}}$ & 4,3 \\
\hline LIG $\quad(\% \mathrm{MS})$ & $4,6^{\mathrm{a}}$ & $4,4^{\mathrm{a}}$ & $3,9^{\mathrm{bc}}$ & $3,5^{\mathrm{c}}$ & $3,1^{d}$ & $3,9^{b}$ & 6,3 \\
\hline DLIG (\%) & 10,1 & 15,9 & 13,6 & 14,4 & 10,4 & 9,9 & 46,8 \\
\hline CEL (\%MS) & $36,4^{a}$ & $34,6^{b}$ & $33,7^{\mathrm{bc}}$ & $32,8^{\mathrm{c}}$ & $23,9^{\mathrm{e}}$ & $28,7^{d}$ & 2,3 \\
\hline CEL* (\%MS) & $36,5^{\mathrm{a}}$ & $33,1^{\mathrm{b}}$ & $29,9^{\mathrm{c}}$ & $29,3^{\text {cd }}$ & $25,1^{\mathrm{e}}$ & $28,1^{d}$ & 3,0 \\
\hline DCEL $(\%)$ & $58,7^{b}$ & $59,9^{\mathrm{b}}$ & $64,5^{\mathrm{a}}$ & $66,0^{\mathrm{a}}$ & $55,9^{\mathrm{bc}}$ & $53,8^{\mathrm{c}}$ & 5,3 \\
\hline DCEL* (\%) & $58,8^{\mathrm{a}}$ & $58,1^{\mathrm{a}}$ & $60,0^{\mathrm{a}}$ & $62,0^{\mathrm{a}}$ & $58,0^{\mathrm{a}}$ & $52,9^{b}$ & 4,8 \\
\hline HEM (\%MS) & $22,5^{\mathrm{a}}$ & $17,5^{b}$ & $12,0^{\mathrm{c}}$ & $10,5^{d}$ & $17,5^{\mathrm{b}}$ & $17,8^{\mathrm{b}}$ & 5,3 \\
\hline HEM* (\%MS) & $22,8^{a}$ & $19,3^{b}$ & $16,4^{\mathrm{c}}$ & $14,8^{d}$ & $16,4^{\mathrm{c}}$ & $18,6^{\mathrm{b}}$ & 6,2 \\
\hline DHEM (\%) & $51,1^{a}$ & $42,5^{b}$ & $30,7^{\mathrm{c}}$ & $26,9^{\mathrm{c}}$ & $53,3^{\mathrm{a}}$ & $53,8^{\mathrm{a}}$ & 19,9 \\
\hline DHEM* (\%) $^{*}$ & $51,8^{\mathrm{ab}}$ & $48,1^{\mathrm{b}}$ & $49,6^{\mathrm{ab}}$ & $48,1^{\mathrm{b}}$ & $50,1^{\mathrm{ab}}$ & $55,7^{\mathrm{a}}$ & 8,9 \\
\hline (\%MS) & $26,8^{\mathrm{e}}$ & $33,6^{\mathrm{d}}$ & $40,5^{b}$ & $42,9^{\mathrm{a}}$ & $43,7^{\mathrm{a}}$ & $37,5^{\mathrm{c}}$ & 3,6 \\
\hline DCNS (\%) & $58,5^{d}$ & $66,2^{c}$ & $72,9^{b}$ & $74,0^{\mathrm{b}}$ & $79,0^{\mathrm{a}}$ & $71,1^{b}$ & 3,6 \\
\hline
\end{tabular}

${ }^{1}$ FB = fibra bruta; DFB = digestibilidade aparente da fibra bruta; FDA = fibra em detergente ácido; DFDA = digestib. apar. da FDA; FDN = fibra em detergente neutro; DFDN = digestib. apar. da FDN; LIG = lignina; DLIG = digest. apar. da LIG; CEL (FDA-LIG) = celulose; DCEL = digest. apar. da CEL; HEM (FDN-FDA)= hemicelulose; DHEM = digest. apar, da HEM.; CNS (100-FDNPB-EE-MM) = carboidratos não estruturais; DCNS = digest. apar. do carboidrato não estrutural.

${ }^{2}$ Médias na mesma linha assinaladas por letras distintas diferiram entre si - Duncan $(\mathrm{P}<0.05)$.

${ }^{3}$ Coeficiente de variação.

* Análises realizadas na forma sequencial (ADF determinado no resíduo do NDF) 
Os teores acina tabulados para as diversas frações fibrosas do tratamento testemunha, são superiores àqueles anteriormente relatados, para o capim napier com 75 dias de desenvolvimento, sendo mais próximos de valores existentes para capins colhidos próximo aos 100 dias de crescimento. Como parâmetro, nos trabalhos de SIL VEIRA et al. (1974), o teor de fibra bruta aos 75 e 105 dias, foram respectivamente de 30,3 e 37,1\%. De forma semelhante, PRÓSPERO (1972), determinou valores de 28,6 e 34,6\% de fibra bruta respectivamente aos 75 e 105 dias de crescimento. Neste caso o valor observado foi de $35,12 \%$. Em outro trabalho de SILVEIRA et al. $\left(1973^{\mathrm{a}}\right)$, os valores de FDN, FDA, celulose, hemicelulose e lignina foram 60,7 e 66,9; 37,7 e 42,8; 29,8 e 33,8; 23,0 e 24,$1 ; 4,6$ e 6,0, respectivamente para os 75 e 105 dias de desenvolvimento do capim napier. Seguindo o raciocínio anterior, os dados aqui apresentados se situariam em nível intermediário entre estes dois valores.

Além das qualidades desejáveis da polpa de citros como aditivo para a ensilagem do capim napier no que se refere às características de fermentação, conforme já discutido anteriormente, um dos principais motivos que culminou na condução deste experimento foi a hipótese de que além de se obter um produto bem conservado, a adição da polpa poderia conduzir a um desempenho animal semelhante ou até mesmo superior à silagem de milho. Esta hipótese foi baseada na presunção de que sendo o capim napier colhido mais precocemente que o milho, apresentaria menor teor e maior digestibilidade da fração fibrosa. A adição da polpa de citros, compensaria a maior digestibilidade dos grãos na silagem de milho, e portanto, ao final nos depararíamos com um produto de qualidade igual ou eventualmente superior.

Diversos são os estudos que demonstram que a polpa de citros pode substituir plenamente o milho em dietas de ruminantes (LUCCI et al, 1975; VAN HORN et al, 1974; BHATTACHARYA e HARB, 1973; KOSSOSKI, 1993), conforme já discutido anteriormente. Quanto à qualidade da fibra do capim napier, também está exaustivamente comprovado que esta sofre acentuada queda no valor nutritivo à medida que ocorre o desenvolvimento do capim (PEDREIRA e BOIN, 1969; VIEIRA e GOMIDE, 1968; 
YEO, 1977). O trabalho de SILVEIRA et al. $\left(1973^{\mathrm{a}}\right)$, anteriormente citado, demonstra claramente que, com o avanço na idade cronológica, os teores dos constituintes da porção fibrosa aumentaram significativamente.

Em relação à qualidade da silagem de milho, NUSSIO (1991), em sua revisão de literatura demonstra que esta reside na quantidade de grãos na massa ensilada. Ele afirma ainda que a qualidade da haste e das folhas é o conceito mais recente introduzido junto a regiões com limitações climáticas, onde a máxima acumulação de matéria seca na planta ocorre bem antes da maturidade dos grãos, e que embora a melhor qualidade de haste do milho seja o objetivo de melhoristas, para a produção de silagem de alta qualidade, seria necessário um incremento da ordem de $20 \%$ em digestibilidade da haste, para compensar a baixa participação de grãos dos materiais denominados tropicais ou forrageiros, ainda assim concorrendo com o baixo teor de matéria seca.

Antes que se faça qualquer inferência sobre os resultados obtidos com a porção fibrosa das silagens, é importante lembrar das considerações realizadas na revisão de literatura, no que se refere à interferência da pectina, nos resultados de análise de fibra em detergente neutro e fibra detergente ácido. Foi mencionado, que a solução de detergente neutro, extrai completamente a pectina, enquanto que a solução de detergente ácido não é totalmente eficaz nesta extração, o que permite a contaminação desta fração, das menos digestíveis, com um carboidrato dos mais digestíveis. A recomendação para contornar tal problema é a análise da fibra em detergente ácido, em sequência à fibra em detergente neutro, ou seja, utilizando-se seu resíduo, que já estaria livre da pectina. Inicialmente isto não foi realizado neste trabalho, tendo a análise da fibra em detergente ácido sido feita em amostra distinta da fibra em detergente neutro. Sendo assim, os valores encontrados para a FDA, e por consequência da celulose, calculada por diferença (FDA - lignina), ficaram superestimados, enquanto que o valor da hemicelulose foi subestimado, uma vez que a pectina não teria interferido no valor da FDN, e esta fração foi calculada como sendo FDN-FDA. Estendendo esta discussão aos valores de digestibilidade destas mesmas frações teríamos que a digestibilidade da FDA e da celulose também foram superestimadas, enquanto que a da hemicelulose foi subestimada. Posteriormente, optou- 
se por refazer as análises de FDN e FDA seguindo a metodologia sequencial. Os valores são apresentados na Tabela 8 destacados por um asterísco na frente da identificação da fração. Com estes dados, a interpretação dos dados ficou alterada para diversas das frações, o que demonstra a importância deste tipo de metodologia de análise quando se está estudando alimentos ricos em pectina como a polpa de citros. Vale lembrar, que a análise da polpa de citros normalmente resulta em valores de FDA superiores aos de FDN, quando feita na forma tradicional, o que resultaria em estimativas do valor da hemicelulose negativos. Análises preliminares realizadas exclusivamente com a polpa de citros, utilizando tanto a metodologia tradicional quanto a sequencial, demonstraram claramente esta condição (Tabela 9).

Tabela 9: Análise da fração fibrosa da polpa de citros por duas metodologias.

\begin{tabular}{lccccc}
\hline Tipo de análise & \multicolumn{5}{c}{ Parâmetros } \\
\cline { 2 - 6 } & FDN & FDA & CEL & HEM & LIG \\
\cline { 2 - 6 } Tradicional & 21,5 & 27,3 & 25,2 & $-\mathbf{5 , 8}$ & 2,1 \\
Sequencial & 22,0 & 18,0 & 15,9 & 4,0 & 2,1 \\
\hline
\end{tabular}

FDN = fibra em detergente neutro; FDA = fibra em detergente ácido;

CEL $($ FDA-LIG $)$ celulose; HEM $($ FDN-FDA $)=$ hemicelulose; LIG = lignina

A discussão dos dados será feita, portanto, tendo como base os dados da análise sequencial. Considerando inicialmente a silagem de milho como termo de comparação, o que se observa é que o comportamento da fração fibrosa não apresenta padrão determinado, sendo que para as diferentes frações ela se compara a diferentes tratamentos, o que deve ser ocasionado pela sua característica de associar uma razoável quantidade de grãos de alta digestibilidade a uma fração fibrosa de baixa digestibilidade. $\mathrm{O}$ que é marcante neste tratamento é que muito embora o teor de fibra em detergente ácido e de celulose sejam baixos, ambos encontrando-se em posição intermediária em relação aos tratamentos T-15 e T-M, suas respectivas digestibilidades foram inferiores a todos os demais tratamentos. $\mathrm{O}$ motivo disto seria uma maior associação entre a celulose 
e a lignina, que limitaria a digestão desta fração. Também curiosamente, este foi o único tratamento que apresentou digestibilidade da hemicelulose próxima à da celulose, o que via de regra é tido como condição normal considerando-se ruminantes segundo VAN SOEST (1994). Portanto, parece que este tratamento, muito embora tenha sofrido a menor restrição em termos de teor de proteína, teve sua digestibilidade prejudicada pela qualidade da fibra através de associações negativas entre seus componentes, podendo ter ocorrido inclusive limitação de carboidratos neste caso.

No que se refere à silagem aditivada com fubá de milho, podemos afirmar que a fração fibrosa e sua respectiva digestibilidade ajudam a explicar o melhor resultado desta silagem na presente condição. Este tratamento apresentou os menores teores de FDN, FDA, celulose e lignina, sendo que a digestibilidade destas frações poderia de modo geral ser comparada àquela determinada para o tratamento com $10 \%$ de polpa de citros. Inversamente, esta foi a silagem que apresentou os maiores teores de carboidratos solúveis, comparáveis aos tratamentos com maiores níveis de polpa de citros, porém com digestibilidade aparente desta fração significativamente superior a todos os demais tratamentos. Quando associamos isto a um teor de proteína bruta superior ao encontrado nas silagens tratadas com polpa de citros, conforme já discutido, novamente concluímos que este tratamento proporcionou melhores condições para fermentação ruminal, e por isso os melhores resultados.

A silagem exclusiva de capim napier apresentou os maiores teores para todas as frações fibrosas como era de se supor, principalmente considerando-se que o capim já havia passado a fase ideal para colheita, porém, no que tange a digestibilidade, seu comportamento foi superior à silagem de milho para as frações FDA e celulose tendo ainda se igualado à silagem aditivada com fubá em relação à digestibilidade do FDN, celulose e hemicelulose. $\mathrm{O}$ teor e a digestibilidade aparente dos carboidratos não estruturais da testemunha foram inferiores a todos os demais tratamentos, o que era de se esperar uma vez que se trata de um material basicamente fibroso. Conforme demonstrado anteriormente este também foi o tratamento que apresentou a maior deficiência protéica, o que certamente limitou a digestibilidade da fibra. 
Quando analisamos as silagens aditivadas com polpa de citros, observamos um comportamento bem típico dos dados, com a diminuição dos teores de todas as frações fibrosas, e aumento do nível de carboidratos não estruturais com o aumento no nível de aditivação. A digestibilidade da fração FDN praticamente não se altera com a adição da polpa de citros, sendo semelhante para todos os tratamentos avaliados. O que fica explícito é a superioridade destes tratamentos em relação à digestibilidade da FDA e da celulose, estando isto relacionado ao baixo teor de hemicelulose e lignina da polpa de citros, o que dá a ela respectivamente condições de alta taxa e extensão de degradação da porção fibrosa, conforme sugerido por PATTON (1994). Outro fator curioso que comprova esta desassociação da celulose da polpa com a lignina é que nas silagens aditivadas com polpa de citros a digestibilidade da celulose foi bastante superior à da hemicelulose, comportamento adverso à maioria dos alimentos fibrosos fornecidos a ruminantes, conforme citação de VAN SOEST (1994). Também a digestibilidade aparente dos carboidratos não estruturais é crescente com o aumento da aditivação, o que mais uma vez deve ter sido influenciado pelo teor de proteína da dieta, pois é possivel observar que a partir do tratamento $\mathrm{T}-10$, quando teoricamente a limitação protéica deixou de ser negativa, a digestibilidade dos carboidratos não estruturais não apresentou diferença estatística entre os tratamentos com polpa de citros, não tendo todavia se igualado ao tratamento aditivado com fubá.

Talvez se possa afirmar, portanto, que a superioridade dos valores de digestibilidade das silagens tratadas com niveis crescentes de polpa de citros, quando comparados à silagem de milho, ficaria creditada principalmente ao seu maior teor de carboidratos não estruturais, que em grande proporção seriam compostos de pectina, uma vez que ambos possuem digestibilidade bastante superior à porção fibrosa, conforme já discutido na revisão da literatura, além de menor teor e maior digestibilidade de algumas das frações fibrosas.

Como fator adicional a esta discussão, poderíamos acrescentar que a silagem de milho apresentou teor relativamente baixo de matéria seca, o que não é usual para este tipo de material. Isto deve ser um fator a se considerar quando se analisa toda esta 
discussão. Este baixo teor de matéria seca pode ter sido decorrente de dois fatores: o primeiro seria a ensilagem em momento inadequado, com os grãos ainda em estágio leitoso, o que não foi o caso; o segundo seria uma pequena quantidade de grãos na massa ensilada, uma vez que os grãos podem ser responsáveis por mais de $50 \%$ na matéria seca da silagem de milho. Admitindo-se esta segunda hipótese como verdadeira poderia ser cogitado que as comparações aqui realizadas seriam de pouco valor, uma vez que compara materiais diferentes em condições não ideais. Porém, voltando aos dados dos teores de fibra da testemunha, observa-se que os valores encontrados foram superiores ao esperado. Infelizmente não foi possivel realizar a ensilagem do material aos 60 dias de desenvolvimento do capim, o que pelos dados já demonstrados da literatura conduziria a teores ainda menores de todas frações fibrosas, bem como aumento de sua digestibilidade. Dessa forma, pode-se afirmar que a presente silagem de capim napier com polpa de citros também não demonstrou todo seu potencial neste experimento e novos estudos, talvez com a utilização de animais em produção seriam interessantes para comparação destes dois tipos de alimentos.

A Tabela 10 apresenta os valores de extrato etéreo e extrativo não nitrogenado das silagens nos diferentes tratamentos. A adição da polpa provocou diminuição do teor de extrato etéreo das silagens, quando comparadas com o tratamento à base de fubá de milho e com a silagem de milho. A polpa é reconhecidamente um alimento com teor muito baixo de extrato etéreo. Pode-se dizer que tanto o teor quanto a digestibilidade do extrato etéreo foram superiores nos tratamentos com fubá $(P<0,05)$ e muito embora a diferença seja pequena ela também contribuiu para o melhor resultado obtido com a silagem aditivada com fubá de milho, uma vez que o extrato etéreo possui maior densidade energética que os carboidratos, e não depende da fermentação ruminal para sua digestão. Já o extrativo não nitrogenado, que seria o correspondente aos carboidratos não estruturais, apresentou aumento significativo tanto nos teores quanto na digestibilidade quando comparamos as silagens aditivadas tanto com PCP quanto com fubá, em relação à testemunha e às silagem de milho. A matéria mineral foi superior nos tratamentos com polpa de citros. 
Tabela 10: Teor e digestibilidade das frações do conteúdo celular.

\begin{tabular}{|c|c|c|c|c|c|c|c|}
\hline \multirow[t]{2}{*}{ Parâmetros ${ }^{1}$} & \multicolumn{7}{|c|}{ Tratamentos ${ }^{2}$} \\
\hline & $T-0$ & $T-5$ & $T-10$ & $\overline{T-15}$ & $\overline{T-M}$ & $\overline{T-S}$ & $\overline{C V}(\%)$ \\
\hline$(\% \mathrm{MS})$ & $2,2^{\mathrm{c}}$ & $2,2^{\mathrm{c}}$ & $2,0^{c}$ & $2,0^{c}$ & $3,1^{\mathrm{a}}$ & $2,8^{6}$ & 9,6 \\
\hline DEE $(\%)$ & $62,5^{\mathrm{b}}$ & $65,5^{b}$ & $68,3^{\mathrm{ab}}$ & $67,4^{b}$ & $76,9^{a}$ & $76,9^{\mathrm{a}}$ & 9,2 \\
\hline ENN (\%MS) & $50,6^{d}$ & $54,0^{\mathrm{c}}$ & $58,6^{\mathrm{b}}$ & $62,8^{\mathrm{a}}$ & $61,8^{\mathrm{a}}$ & $58,8^{\mathrm{b}}$ & 2,4 \\
\hline DENN (\%) & $53,1^{\mathrm{e}}$ & $59,1^{d}$ & $66,0^{\mathrm{bc}}$ & $68,2^{\mathrm{ab}}$ & $70,7^{\mathrm{a}}$ & $62,7^{c}$ & 4,1 \\
\hline $\mathrm{MM} \quad(\% \mathrm{MS})$ & $5,8^{c}$ & $6,4^{\mathrm{ab}}$ & $6,3^{\mathrm{b}}$ & $6,7^{\mathrm{a}}$ & $4,7^{e}$ & $5,2^{\mathrm{d}}$ & 4,1 \\
\hline
\end{tabular}

${ }^{1}$ EE = extrato etéreo; DEE $=$ digestibilidade aparente do extrato etéreo; ENN $=$ extrativo não nitrogenado; DENN = digestibilidade aparente do extrativo não nitrogenado; $M M=$ matéria mineral.

'Médias na mesma linha assinaladas por letras distintas diferiram entre si - Duncan (P<0.05).

${ }^{3}$ Coeficiente de variaçảo. 


\section{CONCLUSÕES}

- A polpa de citros demonstrou se constituir num ótimo aditivo à ensilagem do capim elefante por proporcionar incremento na matéria seca e recuperação da mesma no material ensilado e processo fermentativo adequado, em face dos baixos valores de $\mathrm{pH}$, nitrogênio amoniacal e ácido butírico determinados.

- Muito embora os parâmetros de conservação tenham sido adequados para todos os tratamentos, o nível de $10 \%$ de polpa permitiu uma melhor recuperação de matéria seca, podendo talvez ser indicado como um teor ideal de aditivação.

- Podemos depreender dos resultados obtidos, que os níveis crescentes de polpa de citros foram benéficos ao aproveitamento da silagem pelos animais, o que pode ser atestado pelos valores crescentes de digestibilidade da matéria seca e de NDT.

- Tanto a qualidade quanto a quantidade da proteína na polpa parecem não ser totalmente adequadas, sendo que o teor é baixo e ainda grande parte da proteína na polpa está ligada à fibra, o que requer correção adequada para que o desempenho animal não seja prejudicado.

- A maior digestibilidade de algumas frações da fibra da polpa de citros, seus inerentes baixos teores em hemicelulose e lignina, que limitam respectivamente a taxa e extensão de degradação da fibra a nível de rúmen, e especialmente seu alto teor de carboidratos solúveis e pectina parecem ser os fatores responsáveis pela melhora na digestibilidade das silagens aditivadas com polpa de citros.

- A silagens aditivadas com 10 e $15 \%$ de polpa de citros se igualaram à silagem de milho utilizada no teste, no que se refere à digestibilidade da matéria seca e matéria orgânica e em termos de nutrientes digestíveis totais. Seu consumo voluntário, no entanto foi 
superior à silagem de milho. Ainda em relação à fração fibrosa, a digestibilidade da FDA e da celulose foram superiores nas silagens aditivadas com polpa de citros.

- O fubá de milho se igualou à silagem aditivada com $15 \%$ de polpa no que se refere à digestibilidade da matéria seca e matéria orgânica, tendo superado todas as demais em relação aos nutrientes digestiveis totais, se constituindo talvez numa melhor alternativa, estando a utilização de um ou outro aditivo em função de seu valor de mercado.

- Maiores estudos são necessários para se avaliar possíveis resultados deste tipo de silagens em animais em produção, em especial vacas em lactação, uma vez que a polpa possui padrão de fermentação ruminal bastante distinto, podendo apresentar resultados positivos. Neste caso é recomendável a correta suplementação protéica, para que o desempenho animal não seja limitado por este fator. 


\section{REFERÊNCIAS BIBLIOGRÁFICAS}

ALLRED, K.R. and W.R. KENNEDY. The use of small silos to determine dry matter losses during ensiling. Agronomy Joumal, Madison, 48(7):308-313, 1956

AMARO, A. A. Farelo de polpa cítrica: produção e exportação. Secretaria da Agricultura e Abastecimento, I.E.A. São Paulo, 1978. (mimeo 5 p.).

ANDRADE, I.F. e GOMIDE, J.A. Curva de crescimento e valor nutritivo do capim elefante (Pennisetum purpureum, Schum.) cv. Taiwan A-146. Revista Ceres, Viçosa, v.18, n.100, p.431-447. 1971

ASSOCIATION of OFFICIAL ANALYTICAL CHEMISTS. Official methods of analysis of the Association of Official Analytical Chemists. 12 ed. Washington, DC. 1975. $1015 \mathrm{p}$.

BALWANI, T.L. Soluble carbohydrates of corn plant at different stages of maturity and their digestibility by rumen bacteria. M.S. Thesis. Ohio State University, Columbus, Ohio. 1965.

BHATTACHARYA, A.N. and HARB, M.. Dried citrus pulp as a grain replacement for awasi lambs. Journal of Animal Science. 36(6):1175-1180, 1973.

BEN-GHEDALIA, D., MIRON, J. and YOSEF, E. Fermentation of alfalfa silages with ozonated cotton stalks added. J. Agric. Food Chem. 39:2002, 1991.

BEN-GHEDALIA, D., YOSEF, E., MIRON, J. and EST, Y. The effects of starch and pectin-rich diets on quantitative aspects of digestion in sheep. Anim. Feed Sci. Technol. 24:289, 1989. 
BOIN, C. Elephant (Napier) grass silage production, effect of additives on chemical composition, nutritive value and animal performance. Ihaca. 1975. 215p. (Tese Ph.D. Cornell University)

BOIN, C; MELOTTI, L.; SCHNEIDER, B.H. e LOBÃO, A.O. Ensaio de digestibilidade (aparente) de silagem de sorgo, de milho e de capim napier - I. Boletim da Indústria Animal. Nova Odessa, v. 25 (único). p. 175-186. 1968

CARFAnTAN, J.Y. Política agrícola da CE ameaça o Brasil. Folha de São Paulo. Agrofolha. São Paulo, 24 de Agosto de 1993.

CARVALHO, J.L.H. A parte aérea da mandioca na alimentação animal. Informe Agropecuário. Belo Horizonte. 10(119):28-36, 1984.

CARVALHO, J.L.H. A mandioca: raiz e parte aérea na alimentação animal. Circular Técnica. Centro de Pesquisas do Cerrado - EMBRAPA. Planaltina. 17: 1-36, 1985.

CHESSON, A. and MONRO, J.A. Legume pectic substances and their degradation in the ovine rumen. J. Sci. Food Agric. 33:852, 1982.

CORSI, M. Pastagens de alta produtividade. In: ANAIS DO CONGRESSO BRASILEIRO DE PASTAGENS. ANAIS DO $8^{\circ}$. SIMPÓSIO SOBRE MANEJO DA PASTAGEM. PEIXOTO, A.M. et. al., eds.FEALQ. Piracicaba., 1986. p. 499512.

CORSI, M.; de FARIA, V.P.; PULLICI, C.O.C. Efeito da adição de vários produtos e do murchamento prévio sobre a elevação da matéria seca do capim napier a ser 
ensilado. In: REUNIÃO ANUAL DA SOCIEDADE BRASILEIRA DE ZOOTECNIA. Rio de Janeiro. 1971. p.52-53.

de FARIA, V.P. Efeito da maturidade da planta e diferentes tratamentos sobre a ensilagem de capim elefante (Pennisetum purpureum, Schum.). Piracicaba. 1971. 78 p. (Tese de Doutoramento - ESALQ/USP)

de FARIA, V.P. Evolução no uso do capim elefante: Uma visão histórica. In: ANAIS DO $10^{\circ}$ SIMPÓSIO SOBRE MANEJO DA PASTAGEM. FEALQ. Piracicaba. 1993.p. $19-45$

de FARIA, V.P., TOSI, H. E GODOY, C.R.M. Polpa de laranja fresca e seca como aditivos para a ensilagem do capim elefante napier (Pennisetum purpureum, Schum.). O Solo, Piracicaba, 64(1):41-47, 1972.

EVAGELISTA, A.R.; TEIXEIRA, J.C.; BENTO, L.A. et al. Uso do milho desintegrado com palha e sabugo na forma de aditivo para a produção de silagem de capim elefante (Pennisetum purpureum, Schum.). In: REUNIÃO ANUAL DA SOCIEDADE BRASILEIRA DE ZOOTECNIA. Brasília. 1987. p. 191.

ERWIN, W.S.; G.J. MARCO and E.M. EMERY. Volatile fatty acid analyses of blood and rumen fluid by gas chromatography. J. Dairy Sci. 44:1768-1771, 1961.

FARIAS, I. e GOMIDE, J.A.. Efeito do murchamento e da adição de raspa de mandioca sobre as características da silagem de capim elefante cortado com diferentes teores de matéria seca. Experimentiae. Viçosa. 16(7):131-149, 1973. 
FERREIRA, J.J; MARQUES NETO, J. e MIRANDA, C.S. Efeito da associação de capim elefante (Pennisetum purpureum, Schum.) cv. cameroon e milho na qualidade da silagem e desempenho de novilhas. Revista da Sociedade Brasileira de Zootecnia. Viçosa. 17(3):268-280, 1988.

GAILLARD, B.D.E. The relationship between the cell-wall constituents of roughages and the digestibility of the organic matter. J. Agric. Sci., Cambridg. 59:369, 1962.

GOHL, B.I. Los Subproductos de los citrus para la alimentacion del ganado. Zootecnia. 6:24-27, 1971.

GUTIERREZ, L.E. Identificação de carboidratos e ácidos orgânicos em quatro variedades de capim elefante (Pennisetum purpureum, Chum.) colhidas em três estádios de maturidade. Piracicaba, ESALQ. 1975. 103 p. (Dissertação de Mestrado).

GUTIERREZ, L.E. e de FARIA, V.P. Influência da intensidade do murchamento sobre o teor de carboidratos solúveis do capim elefante (Pennisetum purpureum, Schum.). $O$ Solo. Piracicaba, 68(2):26-31. 1976

GUTIERREZ, L.E. e de FARIA, V.P. Comparação de extratores de carboidratos solúveis em quatro variedades de capim elefante (Pennisetum purpureum, Schum.) colhidas em três estádios de maturidade. O Solo, Piracicaba. 71(1):45-48, 1979.

HALL, M.B. Pectin: The structural non-structural carbohydrate. In: CORNELL NUTRITION CONFERENCE. Cornell University, Ithaca, N.Y. 1995. p. 29-36.

HARRIS JR., B. Using citrus by-products in dairy rations. Florida Cooperative Extension Service. University of Florida. Gainesville. (mimeo 4 p.), 1975. 
HIGHFILL, B.D., BOGGS, D.L., AMOS, H.E. and CRICKMAN, J.G. Effects of high fiber energy supplements on fermentation characteristics and in vivo and in situ digestibilities of low quality fescue hay. J. Anim. Sci. 65:224-234, 1987

JOHNSON, R.N.; BALWANI, T.L.; JOHNSON, L.J.; McLURE, K.E. and DEHORITY, B.A. Corn Plant Maturity II. Effect on in vitro cellulose digestibility and soluble carbohydrate content. J. Anim. Sci.. 25:617-623, 1967.

JUNG, H.G., VALDEZ, F.R., HATFIELD, R.D. and BLANCHETTE, R.A. Cell wall composition and degradability of forage systems following chemical and biological delignification. J. Sci. Food Agric. 58:347, 1992.

KOSSOSKI, A. Resultados do teste com polpa cítrica para vacas leiteiras. Encarte Técnico da Revista Batavo. 18:15-18, 1993.

KRISHNAMOORTHY, U.C.; MUSCARO, T.V.; SNIFFEN, C.J. and VAN SOEST, P.J. Nitrogen fractions in selected feedstuffs. J. Dairy Science. 65:217, 1982.

LAVEZZO, W. Ensilagem do capim elefante. In: ANAIS DO $10^{\circ}$ SIMPÓSIO SOBRE MANEJO DA PASTAGEM. FEALQ. Piracicaba. 1993. p. 169-275.

LAVEZZO, W. e CAMPOS, J. Efeito da adição da cama de galinheiro sobre o valor nutritivo da silagem de capim elefante napier (Pennisetum purpureum, Schum.). Revista Ceres. Viçosa. 24(134):363-370, 1977.

LAVEZZO, W. e CAMPOS, J. Efeito da adição da cama de galinheiro ao capim elefante "Napier" (Pennisetum purpureum, Schum.) sobre as características de fermentação da silagem. Revista Ceres. Viçosa. 25(138): 127-137, 1978. 
LAVEZZO, W; LAVEZZO, O.E.N.M; CAMPOS NETO, O. Qualidade de silagens de capim elefante (Pennisetum purpureum, Schum.) cv. Roxo submetido ao emurchecimento e níveis crescentes de bagaço de cana hidrolisado. In: REUNIÃO ANUAL DA SOCIEDADE BRASILEIRA DE ZOOTECNIA. Anais... Lavras, Sociedade Brasileira de Zootecnia, 1993, p.61.

LUCCI, C.S.; VELLOSO, L.; MASOTTI, N.; RENNÓ, F.P. e BECKER, M. Polpa seca de laranja versus milho desintegrado em misturas concentradas para vacas em lactação. Rev. da Fac. Med. Vet. Zootec. da U.S.P. São Paulo. 12:163-168, 1975.

MACHADO FILHO, L.C.P. e MÜHLBACH, P.R.F. Efeito do emurchecimento na qualidade das silagens de capim elefante cv. Cameroon (Pennisetum purpureum, Schum.) e de milheto (Pennisetum americamum, (L.) Leeke), avaliadas quimicamente. Revista da Sociedade Brasileita de Zootecnia, Viçosa. 15(3):224233, 1986.

McCULlOGH, M.E.; SISK, L.R.; SELL, O.E.; STASCH, A.R and CASON, D.L. Influence of preservatives on the fermentation, nutrient recovery, and value of alfalfa, starr millet, and cowpea and sudan grass silages. J. of Dairy Sci. 43:1827. 1960.

McCULLOGH, M.E. Silage and silage fermentation. Feedstuffs, Minneapolis. 49(13):4950 e $52,1977$.

McDONALD, P. The biochemistry of silage. New York, John Wiley. 226 p. 1981.

McDONALD, P and HENDERSON, A.R. Buffering capacity of herbage samples as a factor in ensilage. J. Sci. Food Agric. 13:395-400, 1962. 
McDONALD, P. and WHITTENBUURY, R. The Ensilage process. In: BUTLER, G.W. e BAILEY, R.W, eds. Chemistry and Biochemistry of Herbage. London, Academic Press. cap. 3, pág 33-60. 1973.

MELOTTI, L. Estudo comparativo da digestibilidade de gramíneas forrageiras com ovinos e bovinos. II. Digestibilidade do capim elefante Napier na forma verde e como silagem. Boletim da Indústria Animal, Nova Odessa, 40(2):267-277. 1983.

MELOTTI, L., BOIN, C., SCHNEIDER, B.H. e LOBÃO, A.O. Ensaio de digestibilidade (aparente) de silagem de sorgo, de milho e de capim napier - II. Boletim da Indústria Animal. Nova Odessa, v. 25 (único), p. 187-195. 1968

MELOTTI, L., CAIELLI, E.L. e BOIN, C. Determinação do valor nutritivo da silagem de capim elefante napier (Pennistum purpureum, SCHUM), através de ensaio de digestibilidade (aparente) com ovinos. Boletim da Indústria Animal, Nova Odessa, v. 27/28 (único), p. 223-230. 1971

NATIONAL RESEARCH COUNCIL. Nutrient requirement of sheep. $5^{\text {th }}$ edition. Nat. Academic Press. Whashington. 1975.

NATIONAL RESEARCH COUNCIL. Nutrient requirement of dairy cattle. Nat. Academic Press. Whashington. 158 p, 1989.

NEAL. W.M.; BECKER, R.B. and DIX ARNOLD, P.T. The feeding value and nutritive properties of citrus by-products. Agricultural Experimental Extension. University of Florida. Gainesville. Bulletin 275. 26 p. , 1935. 
NUSSIO, L.G. Cultura do milho para produção de silagem de alto valor alimentício. IN: ANAIS DO $4^{\circ}$ SIMPÓSIO SOBRE NUTRIÇÃO DE BOVINOS. FEALQ Piracicaba. 1991. Pág. 59-168.

OLIVEIRA, M.D.S; VIEIRA, P.F. e SAMPAIO, A.A.M. Efeito da estocagem sobre a composição bromatológica da cama de frango. Revista da Sociedade Brasileira de Zootecnia. Viçosa. 17(2):115-119. 1988.

PATTON, R. S. Complexities of soluble carbohydrate metabolism in ruminants examined. Feedstuffs. Feb. 14. pág. 13, 1994.

PEDREIRA, J.V.S. e BOIN, C. Estudo de crescimento do capim elefante, variedade Napier (Pennisetum purpureum, Schum.). Boletim da Indústria Animal. 26: 263$273,1969$.

PRÓSPERO, A.O. Variação estacional da composição química-bromatológica, do teor de macronutrientes minerais e da digestibilidade "in vitro"do capim elefante (Pennisetum purpureum, Schum.) variedade Napier. In: ANAIS DA ESCOLA SUPERIOR DE AGRICULTURA “LUIZ DE QUEIROZ”, Piracicaba, 29:81-93. 1972.

SAS Institute Inc. SAS/STAT User's Guide, ed. Cary, NC. 1988.

SCHAILBLY, G.E. and WING J.M. Effects of roughage concentrate ratio on digestibility and rumen fermentation of corn silage citros pulp rations. J. Anim. Sci. 38:697, 1974.

SCHNEIDER, B.H. and FLATT, W. The evaluation of feeds through digestibility experiments. The University of Georgia Press. Athens. 1975. 
SILVEIRA, A.C. Técnicas para produção de silagens. In: Anais do $2^{\circ}$ Simpósio sobre manejo da pastagem. ESALQ. Piracicaba. p.156-186. 1975

SIL VEIRA, A.C. Contribuição para o estudo do capim elefante (Pennisetum purpureum, Schum.) como reserva forrageira no trópico. Botucatu. 1976. 234 p. (Tese Livre Docência - FCMBB/UNESP).

SILVEIRA, A.C.; de FARIA, V.P.; TOSI, H. Efeito da maturidade sobre o valor nutritivo do capim napier. O Solo, Piracicaba. 65(2):35-41, 1973 ${ }^{\mathrm{a}}$.

SILVEIRA, A.C.; TOSI, H. e de FARIA, V.P. Efeito de diferentes tratamentos na digestibilidade "in vitro"de silagem de capim napier (Pennisetum purpureum, Schum.). Revista da Sociedade Brasileira de Zootecnia, Viçosa. 2(2):216-226. $1973^{\mathrm{b}}$.

SILVEIRA, A.C.; TOSI, H. e de FARIA, V.P. Efeito da maturidade sobre a composição química bromatológica do capim Napier (Pennisetum purpureum, Schum.). Revista da Sociedade Brasileira de Zootecnia, Viçosa, 3(2):158-171. 1974.

SNIFFEN, C.J.; O'CONNOR, J.D.; VAN SOEST, P.J.; FOX, D.G. and RUSSEL, J.B. A net carbohydrate and protein system for evaluating cattle diets: II. Carbohydrate and protein availability. J. Anim Sci. 70:3562-3577, 1992.

STROBEL, H.J. and RUSSEL, J.B. Effect of $\mathrm{pH}$ and energy spilling on bacterial protein synthesis by carbohydrate-limited cultures of mixed rumen bacteria. J. Dairy Sci. 69:2941, 1986. 
TOSI, H. Efeito da adição de níveis crescentes de melaço na ensilagem de capim elefante (Penniserum purpureum, Schum.) variedade Napier. Piracicaba. 1972. 87 p. (Tese de Mestrado - ESALQ/USP)

TOSI, H. Ensilagem de gramíneas tropicais sob diferentes tratamentos. Botucatu. 1973. 107 p. (Tese de Doutoramento - FCMBB/UNESP).

VAN HORN, H.H, MARSHALL, S.P.; WILCOX, C.J.; RANDEL, P.F. and WING, J.M. Complete rations for dairy cattle III. Evaluation of protein percent and quality, and citrus pulp-corn substitutions. J. Dairy Sci. 58(8):1101-1108, 1974.

VAN SOEST, P.J. Soluble carbohydrates and the non-fiber components of feeds. Large Animal Veterinarian. Set-Out. pág. 44-50, 1987.

VAN SOEST, P.J. Nutritional ecology of the ruminant. Cornell University Press. Cornell University, Ithaca, N.Y. Second Edition. 1994.

VAN SOEST, P.J; ROBERTSON, J.B. and LEWIS, B.A. Methods for dietary fiber, neutral detergent fiber, and nonstarch polysaccharides in relation to animal nutrition. J. Dairy Sci. 74(10): 3583-3597, 1991.

VIEIRA, L.M. e J.A. GOMIDE. Composição química e produção forrageira de três variedades de capim elefante. Revista Ceres, Viçosa, 15(86):245-260, 1968.

WALDO, D.R. Symposium: Nitrogen utilization by the ruminant. Nitrogen metabolism in the ruminant. J. Dairy Sci. 51:265, 1968.

WALDO, D.R. and GOERING, H.K. Insolubility of proteins in ruminant feeds by four methods. J. Anim. Sci. 49:1560, 1979. 
WEISSBACH, F.; SCHMDT, L. and HEIN, E. Method of anticipation of the run of fermentation in silage making, based on the chemical composition of green fodder. In: PROCEEDINGS OF THE XII INTERN. GRASSLAND CONGRESS. Moscow. Vol II, Part II. 1974. pág. 663-673.

WIERINGA, G.W. Some factors affecting silage fermentation. In: International Grassland Congress. Berkshire. p. 497-502, 1960.

WING, J.M. Effects of physical form and amunt of citrus pulp on utilization of complete feeds for dairy cattle. J. Dairy Sci. 58:63, 1975.

WING, J. M., ed. Citrus feedstuffs for dairy cattle. Extension Bulletin no. 829. Florida Agric. Exp. Station. University of Florida. Gainesville. 25 p. , 1982.

WOOFORD, M.K. The silage fermentation. New York, Marcel Dekker. 350 p. 1984.

YEO, Y. Efeito da maturidade do capim elefante (Pennisetum purpureum, Schum.) variedade Napier, sobre a sua produção e o seu valor nutritivo. Piracicaba. 1977. 96 p. (Dissertação de Mestrado - ESALQ/USP). 


\section{APÊNDICE - Observações realizadas para os diversos parâmetros}

Tabela A1: Recuperação da matéria seca (\%)

\begin{tabular}{|c|c|c|c|c|c|}
\hline & $\mathrm{T}-0$ & $T-5$ & $T-10$ & $T-15$ & $\mathrm{~T}-\mathbf{M}^{*}$ \\
\hline Repetição 1 & 82,36 & 97,07 & 97,85 & 79,08 & 82,75 \\
\hline Repetição 2 & 82,73 & 92,77 & 88,89 & 79,57 & * \\
\hline Repetição 3 & 82,33 & 80,91 & 86,94 & 74,31 & 66,77 \\
\hline Repetição 4 & 79,77 & 78,91 & 96,67 & 87,87 & 77,12 \\
\hline Repetição 5 & 79,40 & 82,65 & 85,27 & 79,36 & 67,78 \\
\hline Médias & 81,32 & 86,44 & 91,12 & 80,04 & 73,06 \\
\hline
\end{tabular}

* Repetição perdida em virtude de não ter sido anotado o peso inicial do silo

Tabela A2: pH das silagens

$\begin{array}{ccccc}\mathrm{T}-0 & \mathrm{~T}-5 & \mathrm{~T}-10 & \mathrm{~T}-15 & \mathrm{~T}-\mathrm{M}\end{array}$

\begin{tabular}{|c|c|c|c|c|c|}
\hline Repetição 1 & 3,85 & $\overline{3,92}$ & 3,76 & $\overline{3,86}$ & 3,78 \\
\hline Repetição 2 & 3,76 & 3,73 & 3,79 & 3,84 & 3,78 \\
\hline Repetição 3 & 3,75 & 3,73 & 3,73 & 3,87 & 3,84 \\
\hline Repetição 4 & 4,01 & 3,81 & 3,73 & 3,77 & 3,80 \\
\hline Repetição 5 & 3,83 & 3,91 & 3,81 & 3,94 & 3,70 \\
\hline Médias & 3,84 & 3,82 & 3,76 & 3,86 & 3,78 \\
\hline
\end{tabular}

Tabela A3: Nitrogênio amoniacal (\% do N-Total)
$\mathrm{T}-0$
$\mathrm{T}-5$
$\mathrm{T}-10$
$\mathrm{T}-15$
$\mathrm{T}-\mathrm{M}$

\begin{tabular}{|c|c|c|c|c|c|}
\hline Repetição 1 & 12,34 & 10,59 & 10,35 & 9,92 & 13,79 \\
\hline Repetição 2 & 13,61 & 10,03 & 11,11 & 10,81 & 11,50 \\
\hline Repetição 3 & 12,58 & 13,15 & 13,31 & 11,31 & 12,88 \\
\hline Repetição 4 & 12,65 & 12,21 & 10,56 & 11,58 & 12,46 \\
\hline Repetição 5 & 12,31 & 13,11 & 12,29 & 10,76 & 12,04 \\
\hline Médias & 12,69 & 11,82 & 11,52 & 10,88 & 12,53 \\
\hline
\end{tabular}


Tabela A4: Teor de matéria seca das silagens. (trat. $x$ período)

\begin{tabular}{|c|c|c|c|c|c|c|}
\hline & $T-0$ & $\mathrm{~T}-5$ & $\mathrm{~T}-10$ & $T-15$ & $\mathrm{~T}-\mathrm{M}$ & $\mathrm{T}-\mathrm{S}$ \\
\hline P I & 19,49 & 21,79 & 25,83 & 26,45 & 25,62 & 25,64 \\
\hline P II & 19,29 & 21,72 & 27,3 & 28,86 & 27,26 & 23,78 \\
\hline P III & 18,54 & 21,47 & 25,94 & 28,06 & 25,48 & 26,5 \\
\hline P IV & 18,23 & 21,11 & 25,06 & 26,46 & 25,99 & 24,94 \\
\hline P V & 18,96 & 20,75 & 24,98 & 28,62 & 26,41 & 24,5 \\
\hline Médias & 18,90 & 21,37 & 25,82 & 27,69 & 26,15 & 25,07 \\
\hline
\end{tabular}

Tabela A5: Consumo de matéria seca (g/kg de peso metabólico). (trat. x carneiro)

\begin{tabular}{|c|c|c|c|c|c|c|}
\hline & $\mathrm{T}-0$ & $T-5$ & $\mathrm{~T}-10$ & $\mathrm{~T}-15$ & $\mathrm{~T}-\mathrm{M}$ & $\mathrm{T}-\mathrm{S}$ \\
\hline C I & 31,16 & 32,01 & 40,1 & 42,2 & 38,88 & \\
\hline C II & 37,09 & 39,48 & 47,91 & & 52,55 & 48,78 \\
\hline C III & 38,63 & & 48,75 & 56,12 & 53,21 & 37,8 \\
\hline C IV & 37,26 & 41,54 & 46,52 & 45,67 & & 39,91 \\
\hline $\mathrm{C} \mathrm{V}$ & 34,9 & 42,08 & & 54,14 & 54,89 & 42,46 \\
\hline C VI & & 44,19 & 49,29 & 50,23 & 55,29 & 40,88 \\
\hline Médias & 35,81 & 39,86 & 46,51 & 49,67 & 50,96 & 41,97 \\
\hline
\end{tabular}

Tabela A6: Digestibilidade da matéria seca (\%). (trat. x carneiro)

$$
\begin{array}{llllll}
\mathrm{T}-0 & \mathrm{~T}-5 & \mathrm{~T}-10 & \mathrm{~T}-15 & \mathrm{~T}-\mathrm{M} & \mathrm{T}-\mathrm{S}
\end{array}
$$

C I

C II

C III

C IV

C V

C VI

Médias

\begin{tabular}{|c|c|c|c|c|c|}
\hline 49,74 & 57,13 & 62,71 & 59,97 & 62,7 & \\
\hline 54,19 & 57,04 & 58,78 & & 63,55 & 60,99 \\
\hline 54,66 & & 61,39 & 63,23 & 66,87 & 54,69 \\
\hline 54,49 & 57,3 & 59,54 & 60,4 & & 61,11 \\
\hline 55,86 & 57,88 & & 63,28 & 65,83 & 60,03 \\
\hline & 51,19 & 61 & 65,35 & 65,76 & 57,79 \\
\hline 53,79 & 56,11 & 60,68 & 62,45 & 64,94 & 58,92 \\
\hline
\end{tabular}


Tabela A7: Digestibilidade da matéria orgânica (\%). (trat. x carneiro)

\begin{tabular}{|c|c|c|c|c|c|c|}
\hline & $\mathrm{T}-0$ & $T-5$ & $\mathrm{~T}-10$ & $\mathrm{~T}-15$ & $\mathrm{~T}-\mathrm{M}$ & $T-S$ \\
\hline C I & 50,03 & 58,68 & 64,3 & 61,21 & 64,03 & \\
\hline $\mathrm{C} \Pi$ & 54,38 & 57,08 & 59,92 & & 64,41 & 62,46 \\
\hline C III & 55,15 & & 61,45 & 64,63 & 67,87 & 56,56 \\
\hline C IV & 55,18 & 58,06 & 61,03 & 60,21 & & 62,99 \\
\hline $\mathrm{CV}$ & 56,32 & 59,13 & & 64,41 & 65,53 & 61,89 \\
\hline C VI & & 52,09 & 61,97 & 66,43 & 66,87 & 57,64 \\
\hline dias & 54,21 & 57,01 & 61,73 & 63,38 & 65,74 & 60,31 \\
\hline
\end{tabular}

Tabela A8: Teor de proteína bruta (\%) das silagens (trat. $x$ carneiro)

\begin{tabular}{|c|c|c|c|c|c|c|}
\hline & $T-0$ & $T-5$ & $\mathrm{~T}-10$ & $T-15$ & $\mathrm{~T}-\mathrm{M}$ & $T-S$ \\
\hline C I & 5,96 & 6,75 & 6,51 & 6,89 & 7,22 & \\
\hline C II & 6,39 & 6,08 & 6,57 & & 6,85 & 8,64 \\
\hline C III & 6,31 & & 6,07 & 6,85 & 7,57 & 7,66 \\
\hline C IV & 6,5 & 6,72 & 6,63 & 6,46 & & 7,55 \\
\hline C V & 6,1 & 6,14 & & 6,69 & 8,95 & 9,57 \\
\hline C VI & & 6,47 & 6,92 & 7,08 & 7,4 & 8,2 \\
\hline Médias & 6,25 & 6,43 & 6,54 & 6,79 & 7,60 & 8,32 \\
\hline
\end{tabular}

Tabela A9: Digestibilidade da proteína bruta das silagens (trat. $\mathrm{x}$ carneiro)

\begin{tabular}{|c|c|c|c|c|c|c|}
\hline & $T-0$ & $T-5$ & $\mathrm{~T}-10$ & T - 15 & $\mathrm{~T}-\mathrm{M}$ & $T-S$ \\
\hline C I & 33,52 & 41,61 & 38,84 & 47,24 & 50,39 & \\
\hline $\mathrm{C} \Pi$ & 50,45 & 42,82 & 46,8 & & 47,59 & 56,49 \\
\hline C III & 48,49 & & 45,98 & 52,38 & 57,76 & 41,37 \\
\hline C IV & 41,33 & 51,11 & 46,64 & 44,83 & & 52,2 \\
\hline $\mathrm{C} \mathrm{V}$ & 49,42 & 42,42 & & 58,4 & 64,16 & 59,93 \\
\hline $\mathrm{C} \mathrm{VI}$ & & 43,95 & 47,91 & 56,46 & 57,52 & 51,55 \\
\hline dias & 44,64 & 44,38 & 45,23 & 51,86 & 55,48 & 52,31 \\
\hline
\end{tabular}


Tabela A10: Teor de FDA (\%) das silagens (trat. x carneiro) - análise tradicional

\begin{tabular}{|c|c|c|c|c|c|c|}
\hline & $\mathrm{T}-0$ & $T-5$ & $\mathrm{~T}-10$ & $\mathrm{~T}-15$ & $T-M$ & $\mathrm{~T}-\mathrm{S}$ \\
\hline C I & 40,7 & 40,77 & 37,06 & 35,85 & 27,77 & \\
\hline C II & 42,62 & 38,66 & 36,91 & & 24,7 & 30,67 \\
\hline C III & 40,47 & & 37,09 & 36,13 & 28,45 & 35,39 \\
\hline C IV & 40,85 & 37,64 & 40,01 & 36,9 & & 31,26 \\
\hline C V & 40,58 & 39,18 & & 35,19 & 27,24 & 34,15 \\
\hline C VI & & 38,64 & 36,8 & 37,8 & 27,28 & 33,3 \\
\hline dias & 41,04 & 38,98 & 37,57 & 36,37 & 27,09 & 32,95 \\
\hline
\end{tabular}

Tabela A11: Digestibilidade da FDA das silagens (trat. $x$ carneiro) - tradicional

\begin{tabular}{|c|c|c|c|c|c|c|}
\hline & $T-0$ & $\mathrm{~T}-5$ & $\mathrm{~T}-10$ & $T-15$ & $\mathrm{~T}-\mathrm{M}$ & $T-S$ \\
\hline C I & 49,1 & 57,97 & 62,09 & 58,34 & 50,02 & \\
\hline C II & 55 & 55,12 & 56,58 & & 43,23 & 45,96 \\
\hline C III & 54,65 & & 58,94 & 61,65 & 53,57 & 44,83 \\
\hline C IV & 53,15 & 54,49 & 59,34 & 58,89 & & 48,81 \\
\hline C V & 53,44 & 56,27 & & 61,22 & 52,09 & 51,01 \\
\hline C VI & & 49,71 & 58,27 & 63,28 & 52,75 & 47,1 \\
\hline dias & 53,07 & 54,71 & $\overline{59,04}$ & 60,68 & 50,33 & 47,54 \\
\hline
\end{tabular}

Tabela A12: Teor de FDN (\%) das silagens (trat. $x$ carneiro) - tradicional

$$
\begin{array}{llllll}
\mathrm{T}-0 & \mathrm{~T}-5 & \mathrm{~T}-10 & \mathrm{~T}-15 & \mathrm{~T}-\mathrm{M} & \mathrm{T}-\mathrm{S}
\end{array}
$$

\begin{tabular}{r|c|c|c|c|c|c|}
\cline { 3 - 7 } C I & 64,12 & 58,72 & 50,18 & 47,81 & 43,87 & \\
\cline { 3 - 8 } C II & 64,5 & 55,22 & 48,32 & & 42,72 & 48,82 \\
C III & 61,99 & & 49,27 & 47,16 & 46,23 & 53,54 \\
C IV & 63,04 & 57,1 & 52,84 & 47,18 & & 47,78 \\
\cline { 3 - 8 } C V & 64,29 & 56,66 & & 45,46 & 43,81 & 51,26 \\
C VI & & 55,01 & 47,6 & 46,85 & 46,28 & 50,95 \\
\hline
\end{tabular}


Tabela A13: Digestibilidade da NDF das silagens (trat. $x$ carneiro) - tradicional

\begin{tabular}{|c|c|c|c|c|c|c|}
\hline & $\mathrm{T}-0$ & $\mathrm{~T}-5$ & $\mathrm{~T}-10$ & $T-15$ & $T-\mathbf{M}$ & $\mathrm{T}-\mathrm{S}$ \\
\hline C I & 49,01 & 55,3 & 57,93 & 52,43 & 48,46 & \\
\hline C II & 53,84 & 50,7 & 47,87 & & 48,17 & 49,11 \\
\hline C III & 52,04 & & 52,03 & 54,18 & 56,11 & 47,48 \\
\hline C IV & 52,63 & 51,92 & 53,08 & 49,67 & & 50,68 \\
\hline C V & 54,64 & 53,88 & & 52,74 & 51,94 & 52,21 \\
\hline C VI & & 43,1 & 50,42 & 56,74 & 53,33 & 49,26 \\
\hline lias & 52,43 & 50,98 & 52,27 & 53,15 & 51,60 & 49,75 \\
\hline
\end{tabular}

Tabela A14: Teor de Lignina (\%) das silagens (trat. $x$ carneiro) $\begin{array}{llllll}\mathrm{T}-0 & \mathrm{~T}-5 & \mathrm{~T}-10 & \mathrm{~T}-15 & \mathrm{~T}-\mathrm{M} & \mathrm{T}-\mathrm{S}\end{array}$

\begin{tabular}{|c|c|c|c|c|c|c|}
\hline C I & 4,45 & 4,76 & 4,45 & 3,48 & 3,61 & \\
\hline C II & 4,74 & 4,2 & 3,55 & & 2,76 & 3,73 \\
\hline C III & 4,73 & & 3,49 & 3,85 & 3,18 & 4,15 \\
\hline C IV & 4,05 & 4,78 & 4,34 & 3,37 & & 3,89 \\
\hline C V & 4,92 & 3,99 & & 3,38 & 2,94 & 4,09 \\
\hline C VI & & 4,22 & 3,49 & 3,66 & 3,18 & 3,95 \\
\hline Médias & 4,58 & 4,39 & 3,86 & 3,55 & 3,13 & 3,96 \\
\hline
\end{tabular}

Tabela A15: Digestibilidade da Lignina das silagens (trat. $\mathrm{x}$ carneiro) $\begin{array}{llllll}\mathrm{T}-0 & \mathrm{~T}-5 & \mathrm{~T}-10 & \mathrm{~T}-15 & \mathrm{~T}-\mathrm{M} & \mathrm{T}-\mathrm{S}\end{array}$

\begin{tabular}{r|c|c|c|c|c|c|}
\cline { 2 - 7 } C I & 11,43 & 28,21 & 32,87 & 9,66 & 25,91 & \\
\cline { 2 - 8 } C II & 18,14 & 7,86 & 11,53 & & 0,53 & 18,12 \\
\cline { 2 - 8 } C III & 15,49 & & 3,35 & 23,54 & 17,12 & 3,41 \\
C IV & $-6,99$ & 27,54 & 23,8 & 5,51 & & 13,53 \\
C V & 12,31 & 5,28 & & 11,53 & 12,19 & 18,23 \\
\cline { 3 - 8 } C VI & & 10,41 & $-3,72$ & 21,7 & $-3,48$ & $-3,8$ \\
\hline
\end{tabular}


Tabela A16: Teor de Celulose (\%) das silagens (trat. $x$ carneiro) - tradicional

\begin{tabular}{|c|c|c|c|c|c|c|}
\hline & $T-0$ & $\mathrm{~T}-5$ & $\mathrm{~T}-10$ & $T-15$ & $T-M$ & $T-S$ \\
\hline C I & 36,24 & 36,00 & 32,62 & 32,36 & 24,16 & \\
\hline C II & 37,88 & 34,46 & 33,35 & & 21,93 & 26,94 \\
\hline C III & 35,73 & & 33,60 & 32,28 & 25,26 & 29,73 \\
\hline C IV & 36,79 & 33,16 & 35,68 & 33,52 & & 27,37 \\
\hline C V & 35,67 & 35,19 & & 31,81 & 24,3 & 30,06 \\
\hline C VI & & 34,42 & 33,31 & 34,40 & 24,1 & 29,35 \\
\hline dias & 36,42 & 34,65 & 33,71 & 32,82 & 23,95 & 28,69 \\
\hline
\end{tabular}

Tabela A17: Digestibilidade da Celulose das silagens (trat. $x$ carneiro) - tradicional

\begin{tabular}{|c|c|c|c|c|c|c|}
\hline & $\mathrm{T}-0$ & $T-5$ & $\mathrm{~T}-10$ & $\mathrm{~T}-15$ & $T-M$ & $T-S$ \\
\hline C I & 54,96 & 61,91 & 66,07 & 63,58 & 53,62 & \\
\hline C II & 59,62 & 62,83 & 61,37 & & 48,62 & 49,81 \\
\hline C III & 59,84 & & 66,48 & 66,2 & 58,16 & 50,31 \\
\hline C IV & 59,89 & 58,37 & 63,67 & 66,25 & & 53,83 \\
\hline $\mathrm{C} \mathrm{V}$ & 59,11 & 62,06 & & 66,5 & 59,12 & 55,47 \\
\hline C VI & & 54,52 & 64,76 & 67,7 & 60,16 & 59,66 \\
\hline Médias & 58,68 & 59,94 & 64,47 & 66,05 & 55,94 & 53,82 \\
\hline
\end{tabular}

Tabela A18: Teor de Hemicelulose (\%) das silagens (trat. $x$ carneiro) - tradicional

\begin{tabular}{|c|c|c|c|c|c|c|}
\hline & $\mathrm{T}-0$ & $T-5$ & $\mathrm{~T}-10$ & $T-15$ & $\mathrm{~T}-\mathrm{M}$ & $T-S$ \\
\hline $\mathrm{CI}$ & 23,42 & 17,95 & 13,11 & 11,96 & 16,1 & \\
\hline C II & 21,87 & 16,56 & 11,42 & & 18,02 & 18,15 \\
\hline C III & 21,51 & & 12,19 & 11,03 & 17,78 & 19,39 \\
\hline C IV & 22,18 & 19,15 & 12,82 & 9,05 & & 16,51 \\
\hline $\mathrm{C} \mathrm{V}$ & 23,71 & 17,48 & & 10,27 & 16,57 & 17,11 \\
\hline C VI & & 16,37 & 10,7 & 10,29 & 18,99 & 17,65 \\
\hline dias & 22,54 & 17,50 & 12,05 & 10,52 & 17,49 & 17,76 \\
\hline
\end{tabular}


Tabela A19: Digestib. da Hemicelulose das silagens (trat. $x$ carneiro) - tradicional

\begin{tabular}{|c|c|c|c|c|c|c|}
\hline & $T-0$ & $T-5$ & $\mathrm{~T}-10$ & $\mathrm{~T}-15$ & $\mathrm{~T}-\mathrm{M}$ & $T-S$ \\
\hline C I & 48,87 & 49,24 & 46,17 & 34,72 & 45,78 & \\
\hline $\mathrm{C} \Pi$ & 51,57 & 40,43 & 19,73 & & 54,94 & 54,45 \\
\hline C III & 47,14 & & 31,11 & 29,68 & 60,19 & 52,44 \\
\hline C IV & 51,47 & 46,85 & 33,51 & 16,6 & & 54,23 \\
\hline $\mathrm{C} \mathrm{V}$ & 56,69 & 48,51 & & 23,7 & 51,69 & 54,62 \\
\hline C VI & & 27,51 & 22,97 & 29,75 & 54,16 & 53,35 \\
\hline lias & 51,15 & 42,51 & 30,70 & 26,89 & 53,35 & 53,82 \\
\hline
\end{tabular}

Tabela A20: Teor de Carboidratos Não Estruturais das silagens (trat. $x$ carneiro)

\begin{tabular}{|c|c|c|c|c|c|c|}
\hline & $\mathrm{T}-0$ & $T-5$ & $\mathrm{~T}-10$ & $\mathrm{~T}-15$ & $\mathrm{~T}-\mathrm{M}$ & $T-S$ \\
\hline C I & 22,53 & 32,30 & 40,79 & 43,39 & 46,19 & \\
\hline C II & 26,80 & 30,74 & 43.41 & & 47,43 & 39,73 \\
\hline C III & 29,61 & & 36,52 & 43,70 & 42,78 & 35,78 \\
\hline $\mathrm{C} \mathrm{IV}$ & 28,52 & 33,21 & 38,34 & 37,44 & & 42,27 \\
\hline $\mathrm{C} \mathrm{V}$ & 26,78 & 35,13 & & 46,28 & 39,07 & 36,42 \\
\hline C VI & & 36,63 & 43,70 & 43,94 & 42,96 & 33,10 \\
\hline Médias & 26,85 & 33,60 & 40,55 & 42,95 & 43,69 & 37,46 \\
\hline
\end{tabular}

Tabela A21: Digestib. dos Carboid. Não Estruturais das silagens (trat. $x$ carneiro)

\begin{tabular}{|c|c|c|c|c|c|c|}
\hline & $\mathrm{T}-0$ & $T-5$ & $\mathrm{~T}-10$ & $\mathrm{~T}-15$ & $\mathrm{~T}-\mathrm{M}$ & $\mathrm{T}-\mathrm{S}$ \\
\hline C I & 56,92 & 62,73 & 71,35 & 70,25 & 77,54 & \\
\hline $\mathrm{C}$ II & 60,75 & 71,13 & 72,64 & & 79,10 & 74,96 \\
\hline C III & 60,86 & & 76,55 & 74,05 & 79,10 & 66,16 \\
\hline $\mathrm{C} \mathrm{IV}$ & 60,37 & 66,27 & 69,78 & 75,82 & & 73,74 \\
\hline $\mathrm{C} \mathrm{V}$ & 53,83 & 66,60 & & 74,49 & 80,02 & 70,75 \\
\hline C VI & & 64,16 & 74,60 & 75,44 & 79,43 & 69,75 \\
\hline édias & 58,55 & 66,18 & 72,98 & 74,01 & 79,04 & 71,01 \\
\hline
\end{tabular}


Tabela A22: Teor de FDA (\%) das silagens (trat. x carneiro) - análise sequencial $\begin{array}{llllll}\mathrm{T}-0 & \mathrm{~T}-5 & \mathrm{~T}-10 & \mathrm{~T}-15 & \mathrm{~T}-\mathrm{M} & \mathrm{T}-\mathrm{S}\end{array}$

\begin{tabular}{c|c|c|c|c|c|c|}
\cline { 3 - 8 } C I & 41,86 & 38,10 & 34,52 & 32,74 & 28,07 & \\
\cline { 2 - 8 } C II & 41,21 & 38,09 & 33,77 & & 29,95 & 31,53 \\
\cline { 3 - 8 } C III & 39,87 & & 33,14 & 32,8 & 27,43 & 33,74 \\
\hline C IV & 40,57 & 37,78 & 34,85 & 33,01 & & 32,31 \\
\hline C V & 42,1 & 35,73 & & 32,58 & 27,05 & 31,15 \\
C C VI & & 37,76 & 32,74 & 33,33 & 28,62 & 32,02 \\
\hline
\end{tabular}

Tabela A23: Digestibilidade da FDA das silagens (trat. $x$ carneiro) - sequencial

\begin{tabular}{|c|c|c|c|c|c|c|}
\hline & $\mathrm{T}-0$ & $T-5$ & $\mathrm{~T}-10$ & $T-15$ & $\mathrm{~T}-\mathbf{M}$ & $T-S$ \\
\hline C I & 50,51 & 55,02 & 59,30 & 54,39 & 50,55 & \\
\hline C II & 53,45 & 54,44 & 52,55 & & 53,18 & 47,42 \\
\hline C III & 53,97 & & 54,04 & 57,76 & 51,84 & 44,18 \\
\hline C IV & 52,93 & 54,29 & 53,32 & 54,05 & & 50,46 \\
\hline $\mathrm{C} \mathrm{V}$ & 55,12 & 52,05 & & 58,11 & 51,74 & 46,29 \\
\hline C VI & & 48,53 & 53,1 & 58,88 & 54,96 & 44,99 \\
\hline Médias & 53,2 & 52,87 & 54,46 & 56,64 & 52,45 & 46,67 \\
\hline
\end{tabular}

Tabela A24: Teor de FDN (\%) das silagens (trat. x carneiro) - sequencial $\begin{array}{llllll}\mathrm{T}-0 & \mathrm{~T}-5 & \mathrm{~T}-10 & \mathrm{~T}-15 & \mathrm{~T}-\mathrm{M} & \mathrm{T}-\mathrm{S}\end{array}$

\begin{tabular}{|c|c|c|c|c|c|c|}
\hline C I & 64,88 & 57,62 & 50,83 & 49,04 & 45,00 & \\
\hline $\mathrm{C} \mathrm{II}$ & 63,52 & 56,56 & 49,97 & & 43,92 & 49,09 \\
\hline C III & 62,74 & & 49,59 & 48,60 & 44,27 & 54,05 \\
\hline C IV & 63,47 & 57,24 & 51,65 & 48,03 & & 49,07 \\
\hline $\mathrm{C} \mathrm{V}$ & 65,18 & 56,20 & & 46,52 & 44,29 & 48,84 \\
\hline C VI & & 56,69 & 49,16 & 46,23 & 45,63 & 52,67 \\
\hline ias & 63,96 & 56,86 & 50,24 & 47,68 & 44,62 & 50,74 \\
\hline
\end{tabular}


Tabela A25: Digestibilidade da NDF das silagens (trat. $x$ carneiro) - sequencial

\begin{tabular}{|c|c|c|c|c|c|c|}
\hline & $\mathrm{T}-0$ & $T-5$ & $T-10$ & $\mathrm{~T}-15$ & $\mathrm{~T}-\mathrm{M}$ & $T-S$ \\
\hline C I & 49,61 & 54,36 & 58,47 & 53,62 & 49,75 & \\
\hline C II & 53,13 & 51,87 & 49,59 & & 49,59 & 49,39 \\
\hline C III & 52,62 & & 52,35 & 55,54 & 54,17 & 48,13 \\
\hline C IV & 52,95 & 52,05 & 51,99 & 50,56 & & 51,98 \\
\hline $\mathrm{C} \mathrm{V}$ & 55,26 & 53,50 & & 53,82 & 52,45 & 49,84 \\
\hline C VI & & 44,78 & 51,99 & 56,16 & 52,67 & 50,92 \\
\hline Médias & 52,71 & 51,31 & 52,88 & 53,94 & 51,53 & 50,05 \\
\hline
\end{tabular}

Tabela A26: Teor de Celulose (\%) das silagens (trat. $x$ carneiro) - sequencial $\begin{array}{llllll}\mathrm{T}-0 & \mathrm{~T}-5 & \mathrm{~T}-10 & \mathrm{~T}-15 & \mathrm{~T}-\mathrm{M} & \mathrm{T}-\mathrm{S}\end{array}$

\begin{tabular}{|c|c|c|c|c|c|c|}
\hline C I & 36,24 & 33,34 & 30,07 & 29,25 & 24,46 & \\
\hline C II & 36,46 & 33,88 & 30,22 & & 27,18 & 27,79 \\
\hline C III & 35,15 & & 29,65 & 28,95 & 24,24 & 29,44 \\
\hline C IV & 36,51 & 33,00 & 30,51 & 29,64 & & 28,41 \\
\hline $\mathrm{C} \mathrm{V}$ & 37,18 & 31,74 & & 29,19 & 24,10 & 27,06 \\
\hline C VI & & 33,54 & 29,25 & 29,67 & 25,44 & 28,07 \\
\hline dias & 36,54 & 33,10 & 29,94 & 29,34 & 25,08 & 28,15 \\
\hline
\end{tabular}

Tabela A27: Digestibilidade da Celulose das silagens (trat. $x$ carneiro) - sequencial

\begin{tabular}{|c|c|c|c|c|c|c|}
\hline & $\mathrm{T}-0$ & $T-5$ & $\mathrm{~T}-10$ & $\mathrm{~T}-15$ & $\mathrm{~T}-\mathrm{M}$ & $T-S$ \\
\hline C I & 56,36 & 58,85 & 63,21 & 59,72 & 54,18 & \\
\hline C II & 58,05 & 62,20 & 57,37 & & 58,54 & 51,36 \\
\hline C III & 59,15 & & 62,01 & 62,31 & 56,40 & 49,56 \\
\hline C IV & 59,59 & 58,17 & 57,52 & 61,83 & & 55,52 \\
\hline $\mathrm{C} \mathrm{V}$ & 60,79 & 57,93 & & 63,51 & 58,79 & 50,53 \\
\hline C VI & & 53,33 & 59,87 & 62,88 & 62,26 & 57,82 \\
\hline Médias & 58,79 & 58,09 & 60,00 & 62,05 & 58,03 & 52,96 \\
\hline
\end{tabular}


Tabela A28: Teor de Hemicelulose (\%) das silagens (trat. x carneiro) - sequencial $\mathrm{T}-0$ $\mathrm{T}-5$ $\mathrm{T}-10$ $\mathrm{T}-15$

$\mathrm{T}-\mathrm{M}$

$\mathrm{T}-\mathrm{S}$

\begin{tabular}{|c|c|c|c|c|c|c|}
\hline C I & 23,02 & 19,42 & 16,31 & 16,30 & 16,93 & \\
\hline C II & 22,31 & 18,47 & 16,20 & & 13,97 & 17,56 \\
\hline C III & 22,87 & & 16,45 & 15,80 & 16,84 & 20,31 \\
\hline C IV & 22,90 & 19,46 & 16,80 & 15,05 & & 16,76 \\
\hline $\mathrm{C} \mathrm{V}$ & 23,08 & 20,47 & & 13,94 & 17,24 & 17,69 \\
\hline C VI & & 18,93 & 16,42 & 12,90 & 17,01 & 20,65 \\
\hline dias & 22,84 & 19,35 & 16,44 & 14,80 & 16,40 & 18,60 \\
\hline
\end{tabular}

Tabela A29: Digestib. da Hemicelulose das silagens (trat. $\mathrm{x}$ carneiro) - sequencial $\begin{array}{llllll}\mathrm{T}-0 & \mathrm{~T}-5 & \mathrm{~T}-10 & \mathrm{~T}-15 & \mathrm{~T}-\mathrm{M} & \mathrm{T}-\mathrm{S}\end{array}$

\begin{tabular}{|c|c|c|c|c|c|c|}
\hline C I & 47,96 & 53,07 & 56,72 & 52,09 & 48,43 & \\
\hline C II & 52,53 & 46,57 & 43,43 & & 41,87 & 52,93 \\
\hline C III & 50,27 & & 48,95 & 50,92 & 57,96 & 54,69 \\
\hline C IV & 52,98 & 47,68 & 49,25 & 42,88 & & 54,90 \\
\hline C V & 55,51 & 56,03 & & 43,78 & 53,57 & 56,10 \\
\hline C VI & & 37,30 & 49,80 & 50,73 & 48,81 & 60,14 \\
\hline dias & 51,85 & 48,13 & 49,63 & 48,08 & 50,13 & 55,75 \\
\hline
\end{tabular}

Tabela A30: Teor de fibra bruta (\%) das silagens (trat. x carneiro)

\begin{tabular}{|c|c|c|c|c|c|c|}
\hline & $\mathrm{T}-0$ & $T-5$ & $\mathrm{~T}-10$ & $\mathrm{~T}-15$ & $T-M$ & $T-S$ \\
\hline C I & 35,19 & 32,33 & 27,08 & 25,22 & 22,81 & \\
\hline C II & 36,33 & 30,86 & 26,75 & & 21,23 & 24,34 \\
\hline C III & 34,06 & & 27,07 & 26,12 & 23,45 & 27,76 \\
\hline C IV & 34,46 & 30,4 & 25,67 & 26,05 & & 24,25 \\
\hline C V & 35,56 & 30,73 & & 24,06 & 22,75 & 27,69 \\
\hline C VI & & 30,25 & 25,98 & 23,45 & 23,16 & 26,94 \\
\hline dias & 35,12 & 30,91 & 26,51 & 24,98 & 22,68 & 26,20 \\
\hline
\end{tabular}


Tabela A31: Digestibilidade da fibra bruta das silagens (trat. $x$ carneiro)

\begin{tabular}{|c|c|c|c|c|c|c|}
\hline & $\mathrm{T}-0$ & $T-5$ & $T-10$ & $\mathrm{~T}-15$ & $\mathrm{~T}-\mathrm{M}$ & $T-S$ \\
\hline C I & 51,65 & 58,71 & 59,18 & 54,07 & 52 & \\
\hline C II & 59,78 & 54,99 & 54,23 & & 48,98 & 52,17 \\
\hline C III & 58,11 & & 55,41 & 57,72 & 56,89 & 52,92 \\
\hline C IV & 56,76 & 54,77 & 53,74 & 49,52 & & 57,25 \\
\hline $\mathrm{C} \mathrm{V}$ & 58,75 & 57,52 & & 57,1 & 56,2 & 59,33 \\
\hline C VI & & 50,26 & 54,2 & 54,92 & 55,1 & 54,73 \\
\hline dias & 57,01 & 55,25 & 55,35 & 54,67 & 53,83 & 55,28 \\
\hline
\end{tabular}

Tabela A32: Teor de extrato etéreo (\%) das silagens (trat. $x$ carneiro)

\begin{tabular}{|c|c|c|c|c|c|c|}
\hline & $\mathrm{T}-0$ & $T-5$ & $\mathrm{~T}-10$ & $\mathrm{~T}-15$ & $\mathrm{~T}-\mathrm{M}$ & $T-S$ \\
\hline C I & 2,09 & 2,22 & 2,51 & 1,90 & 2,71 & \\
\hline C II & 2,31 & 1,85 & 1,70 & & 2,99 & 2,80 \\
\hline C III & 2,09 & & 2,01 & 2,29 & 3,41 & 3,17 \\
\hline C IV & 1,93 & 2,97 & 2,18 & 2,25 & & 2,40 \\
\hline C V & 2,82 & 2,06 & & 1,55 & 3,11 & 2,74 \\
\hline $\mathrm{C} \mathrm{VI}$ & & 1,88 & 1,77 & 2,14 & 3,35 & 2,89 \\
\hline dias & 2,25 & 2,20 & 2,03 & 2,03 & 3,11 & 2,80 \\
\hline
\end{tabular}

Tabela A33: Digestibilidade do extrato etéreo das silagens (trat. x carneiro)

$\begin{array}{llllll}\mathrm{T}-0 & \mathrm{~T}-5 & \mathrm{~T}-10 & \mathrm{~T}-15 & \mathrm{~T}-\mathrm{M} & \mathrm{T}-\mathrm{S}\end{array}$

\begin{tabular}{|c|c|c|c|c|c|c|}
\hline C I & 53,98 & 71,41 & 79,69 & 60,96 & 73,12 & \\
\hline C II & 70,36 & 56,87 & 61,31 & & 73,06 & 83,76 \\
\hline C III & 62,99 & & 64,24 & 75,46 & 79,34 & 78,75 \\
\hline C IV & 56,91 & 74,47 & 75,29 & 65,41 & & 74,47 \\
\hline $\mathrm{C} \mathrm{V}$ & 68,40 & 65,00 & & 58,71 & 78,61 & 63,95 \\
\hline C VI & & 59,93 & 60,92 & 76,33 & 80,29 & 83,73 \\
\hline édias & 62,53 & 65,54 & 68,29 & 67,37 & 76,88 & 76,93 \\
\hline
\end{tabular}


Tabela A34: Teor de extrativo não nitrogenado (\%) das silagens (trat. $x$ carneiro)

\begin{tabular}{|c|c|c|c|c|c|c|}
\hline & $\mathrm{T}-0$ & $\mathrm{~T}-5$ & $T-10$ & $T-15$ & $\mathrm{~T}-\mathrm{M}$ & $\mathrm{T}-\mathrm{S}$ \\
\hline C I & 51,46 & 52,22 & 57,53 & 59,45 & 62,67 & \\
\hline C II & 48,88 & 55,11 & 58,98 & & 64,36 & 58,82 \\
\hline C III & 51,87 & & 58,73 & 58,36 & 60,09 & 56,58 \\
\hline C IV & 51,00 & 53,41 & 58,79 & 58,57 & & 60,95 \\
\hline $\mathrm{C} \mathrm{V}$ & 49,83 & 54,53 & & 61,09 & 60,14 & 60,79 \\
\hline C VI & & 54,98 & 59,02 & 60,10 & 61,63 & 57,11 \\
\hline lias & 50,61 & 54,05 & 58,61 & 62,76 & 61,78 & 58,85 \\
\hline
\end{tabular}

Tabela A35: Digestibilidade do extrativo não nitrog. das silagens (trat. $x$ carneiro)

\begin{tabular}{|c|c|c|c|c|c|c|}
\hline & $\mathrm{T}-0$ & $\mathrm{~T}-5$ & $T-10$ & $\mathrm{~T}-15$ & $\mathrm{~T}-\mathrm{M}$ & $\mathrm{T}-\mathrm{S}$ \\
\hline C I & 50,67 & 60,32 & 68,91 & 65,87 & 69,56 & \\
\hline $\mathrm{C} \Pi$ & 53,97 & 59,70 & 63,65 & & 70,89 & 58,82 \\
\hline C III & 53,78 & & 65,74 & 68,65 & 72,71 & 59,16 \\
\hline C IV & 54,35 & 59,87 & 64,78 & 66,45 & & 66,11 \\
\hline $\mathrm{C} \mathrm{V}$ & 52,66 & 61,79 & & 68,1 & 68,58 & 60,79 \\
\hline C VI & & 53,78 & 67,07 & 71,76 & 71,75 & 58,56 \\
\hline dias & 53,09 & 59,09 & 66,03 & 68,17 & 70,70 & 58,85 \\
\hline
\end{tabular}

Tabela A36: Nutrientes digestíveis totais das silagens (trat.x carneiro)

\begin{tabular}{|c|c|c|c|c|c|c|}
\hline & $\mathrm{T}-0$ & $\mathrm{~T}-5$ & $\mathrm{~T}-10$ & $\mathrm{~T}-15$ & $\mathrm{~T}-\mathrm{M}$ & $\mathrm{T}-\mathrm{S}$ \\
\hline C I & 48,79 & 56,87 & 62,71 & 58,66 & 63,55 & \\
\hline C II & 54,98 & 54,84 & 57,46 & & 64,21 & 61,98 \\
\hline C III & 53,71 & & 59,31 & 62,62 & 68,01 & 53,78 \\
\hline C IV & 52,44 & 57,07 & 58,69 & 58,03 & & 62,14 \\
\hline C V & 54,50 & 56,99 & & 61,3 & 65,27 & 60,45 \\
\hline C VI & & 50,16 & 59,42 & 63,69 & 67,29 & 57,88 \\
\hline dias & 52,88 & 55,19 & 59,52 & 60,86 & 65,67 & 59,25 \\
\hline
\end{tabular}


Tabela A37: Teor de nitrogênio insolúvel na FDA - \% do $\mathbf{N}$ total (trat. $\mathrm{x}$ carneiro)

\begin{tabular}{|c|c|c|c|c|c|c|}
\hline & $T-0$ & $T-5$ & $\mathrm{~T}-10$ & $\mathrm{~T}-15$ & $T-M$ & $\mathrm{~T}-\mathrm{S}$ \\
\hline C I & 12,94 & 12,34 & 14,80 & 13,04 & 7,18 & \\
\hline C II & 12,58 & 17,15 & 12,43 & & 9,31 & 10,86 \\
\hline C III & 12,88 & & 18,8 & 14,97 & 6,4 & 13,51 \\
\hline C IV & 12,22 & 15,1 & 18,97 & 17,35 & & 10,22 \\
\hline C V & 13,85 & 13,6 & & 14,39 & 7,45 & 9,96 \\
\hline C VI & & 14,05 & 14,32 & 14,35 & 9,31 & 11,31 \\
\hline dias & 12,89 & 14,45 & 15,86 & 14,82 & 7,93 & 11,17 \\
\hline
\end{tabular}

Tabela A38: Teor de nitrogênio insolúvel na FDN - \% do $\mathbf{N}$ total (trat. x carneiro)
$\mathrm{T}-0$
$\mathrm{T}-5$
$\mathrm{T}-10 \quad \mathrm{~T}-15$
$\mathrm{T}-\mathrm{M}$
$\mathrm{T}-\mathrm{S}$

\begin{tabular}{r|c|c|c|c|c|c|}
\cline { 2 - 7 } C I & 15,16 & 17,53 & 20,23 & 22,69 & 12,14 & \\
\cline { 2 - 7 } C II & 16,80 & 17,81 & 24,58 & & 13,32 & 14,52 \\
\cline { 2 - 7 } C III & 17,65 & & 24,61 & 21,18 & 11,25 & 17,47 \\
C IV & 14,35 & 16,93 & 25,04 & 21,68 & & 15,13 \\
C V & 15,32 & 21,17 & & 25,21 & 7,88 & 10,86 \\
C V VI & & 22,37 & 22,66 & 22,06 & 16,40 & 14,56 \\
\hline
\end{tabular}

Tabela A39: Teor de nitrogênio solúvel - $\%$ do $\mathbf{N}$ total (trat. $\mathrm{x}$ carneiro)

$$
\begin{array}{lllll}
\mathrm{T}-5 & \mathrm{~T}-10 & \mathrm{~T}-15 & \mathrm{~T}-\mathrm{M} & \mathrm{T}-\mathrm{S}
\end{array}
$$

C I

C II

C III

C IV

C V

C VI

Médias

\begin{tabular}{|l|l|l|l|l|l|}
\hline 52,56 & 58,06 & 56,52 & 58,97 & 60,82 & \\
\hline 55,72 & 53,43 & 56,90 & & 59,62 & 67,25 \\
\hline 55,13 & & 53,34 & 58,67 & 62,61 & 63,07 \\
\hline 56,48 & 57,89 & 57,31 & 57,21 & & 62,50 \\
\hline 53,64 & 54,96 & & 57,73 & 68,37 & 69,76 \\
\hline & 56,29 & 59,13 & 59,13 & 61,80 & 65,51 \\
\hline 54,70 & 56,12 & 56,64 & 58,34 & 62,64 & 65,62 \\
\hline
\end{tabular}


Tabela A40: Teor de nitrogênio não protéico - \% do $\mathbf{N}$ total (trat. $x$ carneiro)

\begin{tabular}{|c|c|c|c|c|c|c|}
\hline & $\mathrm{T}-0$ & $T-5$ & $\mathrm{~T}-10$ & $\mathrm{~T}-15$ & $\mathrm{~T}-\mathrm{M}$ & $\mathrm{T}-\mathrm{S}$ \\
\hline C I & 48,22 & 42,91 & 44,47 & 41,97 & 40,08 & \\
\hline C II & 45,29 & 47,63 & 44,08 & & 42,04 & 33,49 \\
\hline C III & 45,89 & & 47,72 & 42,27 & 38,24 & 37,78 \\
\hline C IV & 44,51 & 43,03 & 43,66 & 44,51 & & 38,36 \\
\hline $\mathrm{C} \mathrm{V}$ & 47,43 & 46,85 & & 43,24 & 32,36 & 30,42 \\
\hline C VI & & 44,72 & 41,80 & 41,12 & 39,07 & 35,28 \\
\hline Médias & 46,27 & 45,04 & 44,35 & 42,62 & 38,35 & 35,07 \\
\hline
\end{tabular}

Tabela A41: Teor de nitrogênio não protéico - \% do $\mathrm{N}$ solúvel (trat. $\mathrm{x}$ carneiro) $\begin{array}{llllll}\mathrm{T}-0 & \mathrm{~T}-5 & \mathrm{~T}-10 & \mathrm{~T}-15 & \mathrm{~T}-\mathrm{M} & \mathrm{T}-\mathrm{S}\end{array}$

\begin{tabular}{l|c|c|c|c|c|c|}
\cline { 2 - 7 } C I & 89,90 & 73,92 & 78,71 & 71,20 & 65,92 & \\
C C II & 81,30 & 89,18 & 77,50 & & 70,47 & 49,82 \\
\hline C III & 83,29 & & 89,51 & 72,07 & 61,08 & 59,92 \\
C IV & 78,84 & 74,43 & 76,22 & 77,80 & & 61,39 \\
C V & 88,49 & 85,25 & & 74,93 & 47,34 & 43,61 \\
C VI & & 79,48 & 70,71 & 69,53 & 63,23 & 53,87 \\
\hline
\end{tabular}

